NBER WORKING PAPER SERIES

MEASURING THE EQUILIBRIUM IMPACTS OF CREDIT:
EVIDENCE FROM THE INDIAN MICROFINANCE CRISIS

\author{
Emily Breza \\ Cynthia Kinnan \\ Working Paper 24329 \\ http://www.nber.org/papers/w24329 \\ NATIONAL BUREAU OF ECONOMIC RESEARCH \\ 1050 Massachusetts Avenue \\ Cambridge, MA 02138 \\ February 2018, Revised January2021
}

We thank Patricia Anghel, Ozgur Bozcaga, Connie Dang, Paul Friedrich, Sumit Gupta, Sang Kim, Taylor Lewis, Cecilia Peluffo, Venkatesh Ramamoorthy, Osman Siddiqi, Gabriel Tourek, and especially Bruno Barsanetti for excellent research assistance. All mistakes are are own. We thank Abhijit Banerjee, Paco Buera, Clement Imbert, Seema Jayachandran, Dean Karlan, Asim Khwaja, Marti Mestieri, Rohini Pande, and Eric Verhoogen for their helpful contributions. We also thank the Microfinance Institutions Network (MFIN) for coordinating the collection of the data and Parul Agarwal and the Centre for Microfinance (CMF) for their help in researching the AP crisis. Anthony D'Agostino generously shared the RBI data. The views expressed herein are those of the authors and do not necessarily reflect the views of the National Bureau of Economic Research.

NBER working papers are circulated for discussion and comment purposes. They have not been peer-reviewed or been subject to the review by the NBER Board of Directors that accompanies official NBER publications.

(C) 2018 by Emily Breza and Cynthia Kinnan. All rights reserved. Short sections of text, not to exceed two paragraphs, may be quoted without explicit permission provided that full credit, including $(\odot$ notice, is given to the source. 
Measuring the Equilibrium Impacts of Credit: Evidence from the Indian Microfinance Crisis Emily Breza and Cynthia Kinnan

NBER Working Paper No. 24329

February 2018, Revised January2021

JEL No. D50,G21,O16

\begin{abstract}
$\underline{\text { ABSTRACT }}$
In October 2010, the state government of Andhra Pradesh, India issued an emergency ordinance, bringing microfinance activities in the state to a complete halt and causing a nation-wide shock to the liquidity of lenders, especially those with loans in the affected state. We use this massive dislocation in the microfinance market to identify the causal impacts of a reduction in credit supply on consumption, earnings, and employment in general equilibrium in rural labor markets. Using a proprietary district-level data set from 25 separate, for-profit microlenders matched with household data from the National Sample Survey, we find that district-level reductions in credit supply are associated with significant decreases in casual daily wages, household wage earnings and consumption. We find a substantial consumption multiplier from credit that is likely driven by two channels - aggregate demand and business investment. We calibrate a simple two-period, two-sector model of the rural economy that incorporates both channels and show that the magnitude of our wage results is consistent with the model's predictions.
\end{abstract}

\author{
Emily Breza \\ Harvard University \\ Littauer Center, M28 \\ 1805 Cambridge Street \\ Cambridge, MA 02138 \\ and NBER \\ ebreza@fas.harvard.edu \\ Cynthia Kinnan \\ Department of Economics \\ Tufts University \\ 8 Upper Campus Road \\ Medford, MA 02155 \\ and NBER \\ cynthia.kinnan@tufts.edu
}




\title{
MEASURING THE EQUILIBRIUM IMPACTS OF CREDIT: EVIDENCE FROM THE INDIAN MICROFINANCE CRISIS
}

\author{
EMILY BREZA $^{\dagger}$ AND CYNTHIA KINNAN $\ddagger$
}

\begin{abstract}
In October 2010, the state government of Andhra Pradesh, India issued an emergency ordinance, bringing microfinance activities in the state to a complete halt and causing a nation-wide shock to the liquidity of lenders, especially those with loans in the affected state. We use this massive dislocation in the microfinance market to identify the causal impacts of a reduction in credit supply on consumption, earnings, and employment in general equilibrium in rural labor markets. Using a proprietary district-level data set from 25 separate, for-profit microlenders matched with household data from the National Sample Survey, we find that district-level reductions in credit supply are associated with significant decreases in casual daily wages, household wage earnings and consumption. We find a substantial consumption multiplier from credit that is likely driven by two channels - aggregate demand and business investment. We calibrate a simple two-period, two-sector model of the rural economy that incorporates both channels and show that the magnitude of our wage results is consistent with the model's predictions.
\end{abstract}

\section{INTRODUCTION}

What is the equilibrium impact of microfinance? Understanding this question is highly relevant: Microfinance is presently one of the only sustainable and scalable vehicles for providing formal credit to poor households who lack physical collateral, and the industry has grown from 23 million to 140 million borrowers worldwide over the past two decades. Accordingly, understanding the impact of microfinance is important for numerous policy questions, with implications for regulation (licensing policy, interest rate caps, and determining who should regulate the sector) and for subsidy policy. ${ }^{1}$ While the partial equilibrium impacts of microfinance are well understood, it has been more challenging to gain

Date: January 2021.

We thank Patricia Anghel, Ozgur Bozcaga, Connie Dang, Paul Friedrich, Sumit Gupta, Sang Kim, Taylor Lewis, Cecilia Peluffo, Venkatesh Ramamoorthy, Osman Siddiqi, Gabriel Tourek, and especially Bruno Barsanetti for excellent research assistance. All mistakes are are own. We thank Abhijit Banerjee, Paco Buera, Clement Imbert, Seema Jayachandran, Dean Karlan, Asim Khwaja, Marti Mestieri, Rohini Pande, and Eric Verhoogen for their helpful contributions. We also thank the Microfinance Institutions Network (MFIN) for coordinating the collection of the data and Parul Agarwal and the Centre for Microfinance (CMF) for their help in researching the AP crisis. Anthony D'Agostino generously shared the RBI data.

${ }^{\dagger}$ Harvard University, Department of Economics, NBER and J-PAL. Email: ebreza@ fas . harvard. edu. ${ }_{\ddagger}^{\ddagger}$ Tufts University, Department of Economics, NBER and J-PAL. Email: cynthia.kinnan@tufts. edu. ${ }^{1}$ For instance, India subsidizes microfinance through its 'priority sector' designation, which allows the sector to access cheap capital. 
traction on the question of how these effects translate to large scale changes in microfinance access that would bring equilibrium forces to bear.

Importantly, microfinance at scale may have multiplier effects through two distinct channels. First, to the extent that individuals consume the proceeds of their microloan, microfinance may increase aggregate demand. Despite the policy goal of directing microfinance toward entrepreneurship, many borrowers use microfinance as a consumption loan (Kaboski and Townsend 2012, Devoto et al. 2012, Tarozzi et al. 2014, Ben-Yishay et al. 2017). ${ }^{2}$ Second, microfinance may stimulate business investment and labor demand. While a series of randomized controlled trials shows only moderate short-run impacts of microcredit on business outcomes (Banerjee et al., 2015b), recent work suggests that the initially-modest impacts of microfinance persist and grow over time, especially for incumbent businesses (Banerjee et al. 2020; Beaman et al. 2020). Moreover, most studies are not designed to detect impacts on non-borrowers, which could be a key driver of multiplier effects.

Through both the aggregate demand and business finance channels, access to microfinance has the potential to push up local wages, impacting the local labor market more broadly. The ability of bank credit to affect labor markets has been shown in the US (Chodorow-Reich, 2014; Mian and Sufi, 2014) and the theoretical potential for microfinance to have a wage effect has been highlighted by Buera et al. (2017). However, to our knowledge, our paper is the first to show empirically that small loans to poor borrowers can in fact move the needle in rural labor markets.

Through expenditure, hiring, and wage impacts, microfinance may give rise to a substantial consumption multiplier. Recent evidence from Kenya documents a large multiplier from cash transfers (Egger et al., 2019), and we might expect multipliers from loans to be even larger in similar contexts. Because, by definition, those taking loans are choosing to bring resources forward in time, this implies that their marginal utility of funds today exceeds the marginal utility of funds in the future. Hence loan proceeds are likely to be spent/invested immediately, rather than held as low-return savings.

To quantify the impacts of microfinance in equilibrium, we study a unique natural experiment that caused a large, exogenous shock to microfinance access at the level of whole labor markets. This unique setting is important as the scale of an RCT is rarely large enough to generate quantitatively large infusions of credit across a large number of markets.

In October 2010, the state government of Andhra Pradesh, India issued an emergency ordinance, bringing microfinance activities in the state to a halt and causing a wave of

\footnotetext{
${ }^{2}$ Note, loans give rise to aggregate demand impacts at the time of origination, when the proceeds are spent. However, most studies do not measure consumption impacts until a year or more after loan disbursal, a timing driven by interest in measuring business impacts. We return to this issue in Section 2.4.
} 
defaults and a nationwide shock to lenders' liquidity. The aggregate gross loan portfolio (GLP) of Indian microlenders fell by approximately $20 \%$, or more than $\$ 1$ billion, between fiscal year 2010 and fiscal year 2011. Panel A of Figure 1 plots India-wide levels of microlending from 2008 to 2013. The drop in lending post-2010 is visible in the figure.

With the help of the largest trade association of for-profit microlenders in India, the Microfinance Institutions Network (MFIN), we collected district-level administrative data from 25s for-profit microlenders detailing their loan portfolios from 2008 through 2013. We combine this information with household-level data from the National Sample Survey (NSS) rounds 64, 66, and 68 (2008, 2010, and 2012, respectively) to create a district-level panel of employment, wages, earnings, consumption, and self-employment activities.

We identify the causal impacts of microfinance by using variation in the balance sheet exposure of each lender to loans in the affected state, Andhra Pradesh (AP), before the crisis, interacted with pre-crisis variation in the geographical footprint of each lender outside of AP. We show that districts that had borrowed more from lenders with portfolio exposure to AP witnessed much larger declines in lending between 2010 and 2012 than similar districts with the same amount of overall pre-crisis lending, but whose lenders did not have balance sheet exposure to AP. Panel B of Figure 1 shows that, while prior to the crisis there was no differential trend in lending in exposed vs unexposed districts, after 2010, districts exposed to the crisis experienced large and significant drops in total microcredit lending, relative to unexposed districts. ${ }^{3}$

We use this massive, differential dislocation in the microfinance market as a source of quasi-exogenous variation to study the effects of district-level reductions in credit supply on consumption, entrepreneurship, wages, and employment. Our empirical strategy only considers districts outside of AP, which were not directly affected by the ordinance and where individuals did not default on their outstanding loans. This natural experiment is a unique opportunity to study large, exogenous, labor-market level shocks to microfinance credit supply in a setting where there were no concurrent demand shocks.

The impacts of this reduction in microcredit were large enough to affect the rural labor market. First, we do indeed find a decrease in the average casual daily wage for the most exposed districts between 2010 and 2012 relative to districts with the same amount of lending, but from less-exposed MFIs. Consequently, the reduction in credit supply causes a

\footnotetext{
${ }^{3}$ Given that the crisis happened at the end of 2010 , one may wonder why the effects of the crisis are most visible in 2012 rather than 2011. This is explained by the fact that most microloans have a maturity of one year. The bulk of the drop in credit came from MFIs delaying the issuance of new loans upon the maturation of existing loans. This means that we only observe changes in microfinance levels with a 6-12 month delay.
} 
decrease in wage labor earnings for the average rural household. We also find that households experience significant reductions in both non-durable and durable consumption. The fall in the wage implies that even non-borrowing laborers may experience declines in earnings and consumption when the local economy is hit by reduced access to credit. Our estimates imply a consumption multiplier of approximately $2.9 .^{4}$

We find evidence consistent with both the aggregate demand channel and the business liquidity channel. In support of the aggregate demand channel, we show that the magnitude of the wage effects on agriculture, where products are tradable and should not respond very intensively to changes in local demand, are roughly half the size of the effects in the nonagricultural sector. Non-agricultural businesses mainly engage in services, construction, or petty trading, all of which are non-tradable and sensitive to changes in local demand. In support of the business investment channel, we show that investment declines in response to exposure to the crisis, and moreover that households are less likely to be employers. ${ }^{5}$

We directly examine district-level outcomes for the tradable sector by studying crop yields. On one hand, firms in the tradable sector, which experiences no adverse shock to demand, will benefit from lower wage bills. But, on the other hand, some of these firms may be forced to scale back as liquidity constraints bind more tightly. Thus, the net impact on tradable sector output is ambiguous. We find a fairly precise zero effect for an index of yields of major crops. This suggests that, in aggregate, any benefits from a fall in the wage are offset by reductions in the scale of production by constrained businesses.

To give context for the magnitude of our results on rural markets, we examine the NSS data on urban areas. The nature of the shock suggests that the effects should be much smaller in urban areas, due to deeper credit markets and more labor- and product-market integration. Moreover, microfinance institutions typically focus the bulk of their lending portfolios on rural areas. Consistent with this prediction, we show that, in large cities, exposure to the AP crisis did not cause changes to consumption, wages, or labor earnings. Only small market towns and rural areas experienced the negative effects of the credit crunch. In other words, while the effects of the credit contraction were significant for rural markets, this is not the case in more urban areas. We also show that our wage results are consistent with a simple calibration of our model.

We provide a battery of robustness tests in support of our identification strategy. We replicate the approach of Khwaja and Mian (2008) to support the claim that our identification strategy captures a change in credit supply, rather than demand. Additionally, we

\footnotetext{
${ }^{4}$ Egger et al. (2019), in comparison, find a multiplier of 2.7 in the case of cash transfers.

${ }^{5}$ While business investment and employment go down, households are more likely to operate a business, suggesting that subsistence self-employment may be a response to slack labor markets (see Breza et al. 2020).
} 
predict the lending footprints of MFIs not in our main sample using the correlation between MFI characteristics and footprint for in-sample firms combined with publicly available portfolio-level information for out-of-sample firms. Using this measure of predicted overall exposure generates similar estimates. Our findings are robust to a number of additional controls, such as proxies for trade, political alignment with Andhra Pradesh, and other initial economic conditions. We also show that "placebo" shocks in other states or time periods do not replicate our results.

The paper is directly related to an active debate on the role of microfinance as a tool for business growth and poverty reduction. A recent wave of papers use RCTs to measure the partial equilibrium impacts of microcredit expansions. Angelucci et al. (2015), Augsburg et al. (2015), Attanasio et al. (2015), Banerjee et al. (2015a), Crépon et al. (2015), and Tarozzi et al. (2015) all find strikingly similar results in a diverse set of countries and settings. This body of short- to medium-run evidence paints a consistent picture of moderate impacts. Increased access to microfinance in partial equilibrium is generally found to cause modest business creation and business expansion. While there is evidence that borrowers do purchase more household durables and business assets, there is almost no support for a large average impact on business profits or on non-durable consumption one to two years post intervention. In a meta-analysis of the RCT evidence, Meager (2019) confirms this general appraisal of small, positive, but generally statistically undetectable effects on most key consumption and business outcomes. In a quasi-experimental study, Kaboski and Townsend (2012) find a very large short-run consumption response to an expansion of village microcredit in Thailand, consistent with many households using the loan proceeds for consumption. Fink et al. (2020) show that, in Zambia, access to lean-season credit is associated with increased consumption and higher village-level wages, and Burke et al. (2018) show that in Kenya, access to harvest-time credit affects local prices by helping farmers delay grain sales. Moreover, Banerjee et al. (2020) show that the entrepreneurial returns to microcredit are heterogeneous and at a longer time horizon are positive and significant for the average household.

Our study differs from RCT analyses in several ways. Most important is the magnitude and scale of the shock. The Andhra Pradesh crisis moved credit by a large amount, both as a percentage reduction in credit and in aggregate: more than $\$ 1$ billion was wiped out of the market. Moreover, this shock played out at the level of entire districts, a large enough area to encompass whole labor markets, allowing us to estimate general rather than partial equilibrium impacts. Achieving variation at this scale via an RCT would be extremely challenging. We also study effects on average borrowers in mature markets, as opposed to 
studying new markets or marginal (complier) borrowers (Beaman et al., 2020). In addition, RCTs may lack power to measure profits for the right tail of the business distribution, yet that tail is likely to have disproportionate influence for aggregate outcomes (see, e.g., Meager, 2020; Hsieh and Olken, 2014). An additional possible difference has to do with timing-RCTs often collect post-intervention data 18 months or more after disbursement of credit, by which time the initial increase in consumption out of loan proceeds will have subsided. Finally, we study the removal of credit while most RCTs study increases in access to credit. ${ }^{6}$ The effects of addition vs. removal of credit may be asymmetric due to, inter alia, loss of borrower-lender relationships when credit is reduced, borrowers having made plans that depended on continued access to credit, or changes in precautionary savings. While we cannot rule out that differences such as the fact that credit was removed rather than added play a role in the difference between our results and the RCT evidence, we show that our calibrated model can replicated the observed treatment effect on wages without introducing an asymmetry between the addition and removal of credit. Our results on credit contractions also speak to the impacts of regulatory tightening, which reduces access to credit. $^{7}$

We attempt to provide complementary evidence to the RCT literature and to fill one of the gaps in the literature highlighted by Banerjee et al. (2015b):

We have only scratched the surface of identifying spillover and general equilibrium effects ... Nonborrowing wage earners could benefit from increased employment opportunities.

More broadly, the paper is related to the literature on financial access for the poor, especially Burgess and Pande (2005), who show evidence that bank expansions decrease rural poverty. This paper also builds on the large literature in macroeconomics and finance studying the effects of credit supply shocks and bank balance sheet effects. Many papers, such as Khwaja and Mian (2008), Paravisini (2008), and Schnabl (2012) have shown that in diverse settings, negative shocks to bank liquidity are often passed on to borrowers through reductions in lending. A smaller literature stemming from Peek and Rosengren (2000) traces out effects of such credit supply shocks on real activity. ${ }^{8}$ The finance literature has typically considered credit supply shocks to the traditional banking sector. In contrast, we explore lending by non-bank entities that target loans toward poor, typically rural households. Our

\footnotetext{
${ }^{6}$ One exception is Banerjee et al. (2018) who find impacts of reduced access to microfinance that are broadly consistent with impacts of increased access.

${ }^{7}$ Restrictive regulatory actions have also taken place in Nicaragua, Bosnia and Morocco.

${ }^{8}$ Other related papers include Chodorow-Reich (2014), Jiménez et al. (2014), Greenstone et al. (2014) and Bustos et al. (2020).
} 
paper is also related to recent work examining general equilibrium effects of large-scale programs and economic shocks in developing countries. ${ }^{9}$

Our paper proceeds as follows. In section 2, we describe the setting and our empirical predictions. Section 3 discusses the data and empirical strategy. Section 4 presents our main results, while Section 5 discusses the interpretation of our findings. Section 6 presents a calibration of a simple two-sector model of the credit contraction to benchmark our results. Section 7 concludes.

\section{Setting ANd Empirical PREDictions}

On October 15, 2010, the AP government unexpectedly issued an emergency ordinance (The Andhra Pradesh Micro Finance Institutions Ordinance) to regulate the activities of MFIs operating in the state through a suite of new restrictions..$^{10}$ These restrictions placed substantial limits on operations and led to mass defaults in the state of AP, with nearly $100 \%$ of borrowers in AP defaulting. Moreover, although there were no significant defaults outside of AP, the liquidity shock nonetheless led to ripple effects through the broader Indian microfinance sector.

2.1. Origins of the Ordinance. The ordinance made three claims: 1) that MFIs charged usurious interest rates; 2) that they used coercive methods to collect their debts; and 3) that they exploited self-help groups (SHGs) (Kinetz, 2011). The first two claims generally sounded alarms about consumer protection. The third focused specifically on the effects of microfinance on SHGs, a competing government-led financial inclusion program. A debate has emerged in policy circles whether the ordinance was an honest attempt to regulate a rogue industry or a political play to support SHGs and to serve clientelistic aims with indebted rural voters.

Microfinance is an inherently difficult financial product to regulate. Thousands of loan officers (typically male) travel independently to rural villages to make collections from borrowers (typically female), and stories of coercive collection practices are not uncommon (Rai, 2010). In the months prior to the ordinance, there was intense media coverage of a set of farmer suicides in 2010 in AP that were allegedly linked to MFI overindebtedness (see, e.g., Ris 2010). Moreover, in August 2010, the AP-based MFI SKS raised \$350M of

\footnotetext{
${ }^{9}$ See Imbert and Papp (2015), Muralidharan et al. (2017), Jayachandran (2006), Akram et al. (2017), Cunha et al. (2019) and Attanasio and Pastorino (2020).

${ }^{10}$ Specifically, all NBFC-MFI regulated entities needed to immediately suspend operations and register with the district-level authorities before resuming any disbursements or collections in that district. The ordinance also capped interest rates at $100 \%$, mandated that collections be made in a public place, and prohibited MFIs from lending to members of Self-Help Groups (SHGs) (Cole and Saleman, 2015).
} 
equity capital in an IPO that was 13 times oversubscribed. The high market valuation of SKS raised questions about microfinance's social mission and the ethics of profiting on the backs of the poor (Sriram, 2012; Cole and Saleman, 2015).

Critics of this consumer protection narrative argue, however, that the government used the MFIs as a convenient scapegoat (Taylor, 2011; Roodman, 2010). ${ }^{11}$ While microfinance is only one part of household liabilities, the ordinance exclusively targeted MFIs. There was no attempt to rein in coercive practices and high interest rates of loan sharks or other types of financing corporations. Moreover, the $100 \%$ interest rate cap put in place by the ordinance was far higher than the rates any lenders were charging at the time (approximately $30 \%$ ). Cole and Saleman (2015) argue that the AP government was used the language of the cap to stoke popular outrage.

Critics of the ordinance claim that its primary aim was to reduce competition with the government's rival SHG program (Yerramilli, 2012). ${ }^{12}$ Andhra Pradesh was India's leader in promoting the SHG model, and the government used the program for political gain in rural communities (Sriram, 2012). Moreover, debt forgiveness of the borrowers from competing MFIs is consistent with other politicized interventions in lending markets (Cole, 2009). The consensus in many policy and academic circles is that politics and anti-competitive motives were the most important causes of the crisis, and AP's role as the poster child for the SHG movement was the driving factor in why the ordinance was issued there. We discuss below how these causes of the ordinance inform our identification strategy.

2.2. Impacts of the AP Ordinance Across India. While the ordinance clearly hobbled lending operations in AP, there were almost immediate spillovers to the rest of the country. Specifically, Indian banks, the main source of funding for the sector, largely refused to issue new loans to MFIs across India. These effects can be seen in the aggregate country-wide patterns displayed in Figure 1, Panel A. Using data from the Microfinance Information Exchange (MIX), the figure shows that total microfinance loan portfolios fell by over one billion US dollars following the crisis. ${ }^{13}$ The figure also shows that lending did begin to

\footnotetext{
${ }^{11}$ There is a long history of politicizing farmer suicides in India, and analyses of the financial situations of the households that experienced suicides does not line up with microfinance as the main culprit (Rai, 2010; Yerramilli, 2012; Rao, 2010; Johnson and Meka, 2012).

${ }^{12}$ In fact, the sub-heading of the ordinance itself is "An Ordinance to protect the women Self Help Groups from exploitation by the Micro Finance Institutions in the State of Andhra Pradesh."

${ }^{13}$ Note that the crisis hit the lender's loan portfolio with a lag. Given the year-long maturity of most microloans, it took twelve months for the loans to fully default. Further, many MFIs waited to write off their non-performing loans. Additionally, many lenders report annual data at the end of the fiscal year, which in India is often early in the calendar year.
} 
recover in 2013. This timing coincides with the RBI taking over full regulatory authority of for-profit MFIs in mid-2012, foreclosing the possibility of similar ordinances elsewhere.

What is important for this paper is that lending even in areas outside of Andhra Pradesh was affected by the crisis. Notably, the shock in AP was transmitted to other districts through the balance sheets of the lenders - that is, MFIs with high exposure to the defaults in AP were forced to reduce their lending in other states that were not directly affected. In general, they were not able to secure additional financing from the Indian banks to maintain their desired levels of lending. Perhaps surprisingly, the defaults in AP did not spread across the country: individuals continued to make their loan repayments even though they may have anticipated that their lender would not be able to give them more credit immediately upon full repayment. ${ }^{14}$

2.3. Identifying the Role of the Crisis. We use exposure to the AP Ordinance as an exogenous shock to the microfinance sector outside of AP, allowing us to identify the impacts of the decline in credit on market level outcomes. The above discussion suggests that there are a few important considerations when constructing our identification strategy.

First, policy-makers and MFIs were worried at the time that other states might adopt a similar regulatory stance. Places more at risk for policy contagion include states with more aggressive microfinance lending, more indebtedness, higher penetration of SHGs, and the same governing party as Andhra Pradesh. In our core specifications, we therefore allow for differential trends by the pre-crisis microcredit level and microcredit growth. We also test the robustness of our findings to inclusion of differential trends by SHG penetration and political party affiliation.

Second, the footprints of the lenders, while pre-determined, are not random. As shown in Appendix table C.1, exposed districts are, unsurprisingly, closer to AP. This raises the concern of direct spillovers from AP onto other exposed districts, through channels other than lending. Such spillovers are a priori unlikely: borrowing firms tend to be extremely small in scale and unlikely to be selling across district borders. Tradable goods such as agricultural output are sold in local markets or to traders. Nonetheless, spatial spillovers of some kind may be possible. In our core analysis we allow for differential trends by

\footnotetext{
${ }^{14}$ In conversations with executives from six lenders, we learned that many MFIs went to great lengths to manage the expectations of borrowers. The loan officers played a significant role in explaining disbusement delays and answering borrowers' questions. The lenders believed that the continuous presence of loan officers in the villages gave borrowers confidence that they would eventually be given new loans.
} 
distance to AP. Moreover, we conduct a number of robustness checks to show that such spatial spillovers are not driving our results. ${ }^{15}$

2.4. The impact of credit in equilibrium. There are two main channels-investment and aggregate demand - through which changes in microfinance supply might impact labor market equilibrium, and in turn, produce a consumption multiplier.

Investment Channel. A rich theoretical literature has analyzed the potential for credit directed at poor households to matter via the channel of business creation and expansion (e.g., Banerjee and Newman 1993, Buera et al. 2017, Ahlin and Jiang 2008). A contraction in credit supply should decrease both investment and labor demand for the firms owned by microfinance borrowers and put downward pressure on wages. Because of the fall in firm profits for borrowing entrepreneurs and wage earnings for workers, a credit contraction should also lower consumption for these groups. ${ }^{16}$

While the RCT literature finds little short-run evidence of effects of microfinance on business scale or profitability for the average complier, Banerjee et al. (2020) find that, over a longer time horizon, the average wage bill more than doubles in neighborhoods treated with access to microfinance, relative to control, and incumbent firms earn $28 \%$ higher profits. Relatedly, Banerjee et al. (2018) find that, when microfinance borrowers stop borrowing (due to a requirement to purchase health insurance), there are negative effects on incumbent businesses. This evidence suggests that a large reduction in credit may impact firm profits and hence hiring through the investment channel.

Aggregate Demand Channel. Microfinance is not only used for businesses. For example, in Banerjee et al. (2015a), only $49 \%$ of microfinance borrowers have any business 1-2 years post-intervention. Microfinance may be particularly useful in allowing households to purchase lumpy consumption goods that are difficult to save up for (see, e.g., Devoto et al. 2012, Tarozzi et al. 2014, Ben-Yishay et al. 2017.) Moreoever, Kaboski and Townsend (2012) find that short run consumption responds nearly one-for-one with increased credit in Thai villages. It is notable that Kaboski and Townsend (2012)'s high frequency data allow them to measure the consumption response immediately after the increase in credit access, which is precisely the time at which the loan proceeds are spent, and hence, to the extent that some of the spending is on locally-priced goods or services, will affect

\footnotetext{
${ }^{15}$ Specifically, we remove border districts from the analysis, check robustness by sequentially dropping states, and allow for differential trends by trade costs with AP (Allen and Atkin, 2016).

${ }^{16}$ In contrast, firms in the same labor market that do not borrow from microfinance should benefit from the fall in wages (Buera et al., 2017). This should increase the labor demand of these unconstrained firms, partially offsetting the fall in equilibrium employment.
} 
local aggregate demand. Microfinance RCTs, on the other hand, tend to measure postintervention outcomes a year or more later, to coincide with the likely timing of impacts on, e.g., business profits.

These results imply that there is scope for a market-wide reduction in microcredit to decrease aggregate demand. When individuals borrowing for consumption purposes lose access to credit, their short-run consumption falls, lowering the demand for goods and services. This could lead to a reduction in labor demand, with consequences for equilibrium employment and wages. Note that reduced business spending will also have aggregate demand implications if such spending comprises locally-priced assets or working capital.

In Appendix A, we use a two-period model to isolate the impact of a decrease in credit supply on wages via the aggregate demand channel. Our model contains two sectors: tradable goods (e.g., agriculture) can be sold to the national or global market, while nontradable goods (e.g., services or local retailers) can only be sold to the local market and so are locally priced. We show that when tradable sector workers are imperfect substitutes for non-tradable sector workers, wages in both sectors fall following a credit contraction, with the non-tradable sector wage falling by more.

We focus the model on the aggregate demand channel for several reasons. One, to our knowledge this channel has received less attention in the context of microfinance. While theories of the investment channel have long been applied to microfinance, the aggregate demand channel has received much less attention in the microfinance literature. ${ }^{17}$ Second, given the active debate about whether microfinance leads to significant effects on business outcomes for the average borrower, we feel there is value in highlighting the role for the aggregate demand channel. Empirically, the aggregate demand channel is also much harder to study with partial equilibrium analysis.

The two channels can also interact and amplify one another. For example, if loans taken for business investment are used to purchase locally-priced inputs, or if business profits are used to buy locally-priced consumption goods or services, this would lead to a stronger reduction in aggregate demand.

Empirical Predictions. We next outline a set of empirical predictions, combining both channels. Our goal is not to tease the channels apart, especially because they may have important interactions, but to understand the equilibrium profile of microfinance impacts.

Both channels predict a fall in labor demand in response to a microcredit contraction. This reduction in demand leads to a reduction in wage employment, wage levels and wage

\footnotetext{
${ }^{17}$ The aggregate demand channel has been well-studied in other consumer lending contexts. See, for example, Mian and Sufi (2014); Mian et al. (2017).
} 
earnings. If the aggregate demand channel is at play, we should expect a larger decline in wages for non-tradable vs. tradable labor. In addition, the aggregate demand channel suggests a fall in expenditure on locally-priced goods (e.g., construction). The investment channel is expected to manifest through a reduction in employment and capital expenditure.

There are several forces that put downward pressure on consumption and that could produce a multiplier effect. First, individuals who borrow for consumption experience a direct consumption decrease when credit supply falls. Second, consumption should also fall for workers facing lower earnings. Third, credit-constrained entrepreneurs who borrow from microfinance should experience lower profits from forgoing profitable investments. Finally, if firm profits decline in the non-tradable sector due to a decrease in aggregate demand, both borrowers and non-borrowers should experience a decline in profits. The only segment of the market that is insulated from both the investment and the aggregate demand channel is non-borrowing (unconstrained) entrepreneurs in the tradable sector.

We next detail the data and empirical strategy and present event-study figures in support of our identifying assumption.

\section{DATA AND EMPIRICAL StRATEGy}

3.1. Data. Our goal is to use the district-level, quasi-random variation in microfinance access generated by the AP crisis to obtain causal estimates of the impact of access to finance outside of AP. First we discuss how we measure exposure to the AP crisis and the data required. We then discuss our outcome data. Finally we discuss our differencein-difference identification strategy and present evidence in support of the parallel trends assumption. Appendix D provides additional details.

Proprietary MFI Data. Our first requirement is a measure of district-level balance sheet exposure to Andhra Pradesh before October 2010. Because no commonly-available datasets contain such information, we partnered with the Microfinance Institutions Network (MFIN), the primary trade organization of for-profit MFI-NBFCs (non-bank, financial corporations), who comprise the bulk of microloan volume. MFIN allowed us to ask their 42 members for district-level balance sheet snapshots from 2008 to 2012; 25 of MFIN's member organizations agreed to share their data.

Given that we do not observe the universe of Indian MFIs, we explore the sample composition. We can cross-check our sample with the aggregate data that many firms choose to report to MIX Market, an online repository of information about global microfinance. We examine characteristics of MFIs in 2009, the year before the AP crisis. In total, 115 Indian MFIs provide 2009 data to MIX. Of the 25 MFIs in our sample, 21 report to MIX; these 
comprise $36 \%$ of all reporting for-profit lenders in India. Our sample represents approximately $18 \%$ of the total microfinance market by loan volume.

Table 1 examines the selection of reporting firms into the sample. In panel A, we observe that the reporting firms are smaller: they have fewer borrowers and fewer borrowers per staff member. This is not surprising given that several of the largest lenders in India, who have achieved greater economies of scale, chose not to participate in our study. ${ }^{18}$ However, the loan-level details look much more similar between reporting and non-reporting firms; the average loan sizes are around $\$ 180$ and are not statistically different, and the default rates (write-offs and 30-day portfolio at risk) are quite low in both samples. (Though the 30-day portfolio at risk is lower in the reporting sample.)

In Panel B, we restrict the sample to reporting firms and examine whether the characteristics of firms exposed to the crisis (i.e., firms with loans in AP on the eve of the crisis; see below) have different characteristics than those which are not exposed. Whereas differences between reporting firms and non-reporting firms in Panel A affect the external validity of our results, any differences between exposed and unexposed lenders could pose a threat to internal validity. Reassuringly, exposed and unexposed firms look quite similar in terms of loan size, number of borrowers, borrowers per staff member, write-off ratio and portfolio at risk. We examine an additional outcome within this sample: the MFI's age, as measured by the first year it reports positive loan volume in our data. (We cannot examine this outcome in Panel A since it is only available for reporting firms.) Exposed and unexposed firms are also similar in this dimension. In Sections 4.1 and 5.1 we further explore the robustness of our results to our only observing a subset of MFIs.

Based on the final MFI data set, Table 2 Panel A shows that the total 2012 gross loan portfolio of reporting lenders in districts where lenders were not exposed to the crisis is roughly INR 124 million.

Measuring exposure to the AP Crisis. In order to calculate the level of exposure of each district to the AP crisis, we proceed as follows. First, for each lender $l$, we calculate the share of the MFI's overall portfolio that was invested in Andhra Pradesh on the eve of the AP Crisis (the beginning of October, 2010):

$$
\operatorname{frac} A P_{l}=\frac{G L P_{l, A P, O c t 2010}}{G L P_{l, T o t a l, O c t} 2010}
$$

\footnotetext{
${ }^{18}$ This is likely because the larger lenders had more outside equity holders and wanted to maintain data privacy. They also had the most to fear from negative press coverage.
} 
Then, for each district $d$, we construct an aggregate exposure measure by taking the weighted average of $f r a c A P_{l}$ over all lenders who had outstanding loans in the district precrisis, where the weights are that lender's total loan portfolio in the state, $G L P_{d, l, O c t 2010}$ :

$$
\operatorname{Exp} A P_{d}=\frac{\sum_{l} \operatorname{frac} A P_{l} \times G L P_{d, l, O c t} 2010}{\sum_{l} G L P_{d, l, O c t 2010}} .
$$

$\operatorname{Exp} A P_{d}$ is a measure of the extent to which the district's loan portfolio on the eve of the crisis was exposed to the crisis. For instance, consider a district served by two lenders, each of whom makes $50 \%$ of the loans in the district. One lender operates solely in Northern India and has $0 \%$ of its portfolio in AP, while the other is based in Southern India and has $40 \%$ of its portfolio in AP. Then $\operatorname{Exp}_{A} P_{d}=\frac{.4+0}{2}=0.20$. Appendix Figure C. 1 shows a map depicting the level of exposure for each district in our sample; summary statistics can be found in Table 2 .

NSS Data. Our primary outcome measures come from the Indian National Sample Survey (NSS). In our core empirical specification, we use household data from waves 64, 66, and 68 of the NSS, which correspond to years 2007-2008, 2009-2010, and 2011-2012, respectively. ${ }^{19}$ The NSS surveys are designed to be nationally representative, and we use sampling weights in all of our regressions. We focus on the schedules containing household composition, consumption and employment. Key variables are summarized in Table 2. (We summarize the 2012 values in low exposure districts for ease of comparison to the reduced form results, below.) An average household works 10.28 days per week. Those days are split roughly $\frac{2}{3}$ self-employment (typically agricultural) and $\frac{1}{3}$ non-self employment. Nonself-employment activities are largely comprised of casual (non-permanent) wage jobs. Household total weekly wage earnings average INR 855 . The agricultural casual daily wage averages INR 140, and the non-agricultural casual daily wage averages INR $195 .^{20}$ Households only report working in public works (the NREGA program) in $2 \%$ of weeks.

The NSS waves 64, 66, and 68 do not contain detailed data on household indebtedness. However, as discussed below, we can use the NSS 70th wave contains a "Debt and Investment" survey, collected in 2012 and 2013. We use information on household borrowing as of June 30, 2012. The average household in a low-exposure district had INR 2412 in outstanding microloans (Table 2 Panel $\mathrm{C}$ ). Note that these measures average across borrowers and non-borrowers.

\footnotetext{
${ }^{19}$ We also use data from waves 60,61 , and 62 in our pre-trend analysis (Section 3.3).

${ }^{20} \mathrm{We}$ exclude work performed as part of public works programs such as NREGA from the wage calculations since NREGA wages are set administratively, not via market clearing.
} 
Auxiliary Data Sources. Finally, throughout our analysis we introduce several outcomes and covariates from several complementary data sources. These cover variables such as rainfall, inter-district travel times, political party affiliation, and crop yields. We describe the sources of those variables when we introduce the empirical specifications and results, below; more detail is available in Appendix D.

3.2. Empirical Strategy. We estimate ITT impacts of reduced access to microfinance on a range of outcomes. The main estimating equation takes the difference-in-difference form

$$
y_{i d t}=\alpha+\delta_{t}+\delta_{d}+\beta \times \text { Exposure }_{d} \times \text { Post }_{t}+X_{i d t}^{\prime} \gamma+\varepsilon_{i d t}
$$

where $y_{i d t}$ are outcome variables for individual $i$ in district $d$ at time $t ; \delta_{t}$ and $\delta_{d}$ are fixed effects for survey round (time) and district, respectively; Exposure $e_{d}$ is a measure of the exposure of district $d$ to the AP crisis (discussed above); and $\beta$ is the coefficient of interest. The vector $X_{i d t}^{\prime}$ includes controls for the calendar month of the survey and household size. We also include a number of controls for pre-crisis, district-level outcomes interacted with time dummies; this allows for differential unrestricted time effects that are functions of these pre-crisis characteristics. These outcomes are: the 2010 rural population of the district at $t$ and its square, dummies for quintiles of 2008 and 2010 gross loan portfolio, linear distance from the district centroid to Andhra Pradesh, the district average level of per-capita consumption in 2010, and the district average casual daily wage in 2010. Note that we do not observe a household panel, but rather repeated cross-sections, which form a district-level panel. Standard errors are clustered at the district level.

We use two measures of exposure to the AP crisis. Our preferred measure is the exposure ratio $\operatorname{Exp} A P_{d}$ (defined by equation 3.1). While this is the most natural measure, emerging directly from the effect of the crisis on lenders, for ease of interpretation we also present a binary indicator for the presence of any lender that had exposure to the AP crisis, $\operatorname{Exp}_{A} P_{d}>0$. The proportion of districts with positive exposure is $37.3 \%$; the proportion of household-level observations located in these districts is very similar, at $36.9 \%$.

Our identification comes from the differential change in outcomes of household cohorts in otherwise-similar districts with differing degrees of exposure to the crisis. Given the controls we include, our identifying assumption is that households in districts with the same rural population, the same levels of total MFI lending in 2008 and 2010, the same distance to AP, and the same 2010 levels of consumption and wages, are on similar trends regardless of whether the MFIs lending in the district were highly exposed to the AP crisis. 
One piece of evidence supporting this assumption is the fact that microlenders before the crisis tended to offer a very homogeneous product. Most lenders used all of the following features: interest rates of approximately 25-30\% APR, weekly or monthly meetings, meetings held in groups, similar loan sizes, and similar dynamic incentives. Given this standardization, the identifying assumption is a priori reasonable. Moreover, we present a number of robustness and placebo checks below that lend direct support to this assumption.

As a way to shed further light on our identification strategy, Table C.1 compares baseline characteristics of exposed vs. unexposed districts. (Recall that, since we use a differencein-difference strategy, level differences across exposed vs. unexposed districts do not in and of themselves pose a concern, but trend differences would be a concern; we discuss this further in the next subsection.) Columns 1 and 2, respectively, examine whether exposed districts are closer to AP or more likely to border AP. Unsurprisingly, they are: MFIs that operated in AP also operated in nearby districts. Accordingly, all of our empirical specifications control for distance to AP. Columns 3 through 7 shows that exposed and unexposed districts do not differ in their baseline levels of agricultural or non-agricultural daily wages, weekly labor earnings, or non-durable or durable consumption. In Section 4.4 , we will show a variety of checks to rule out that differential trends by distance are driving our results. The results in section 4.1, which show that all of the fall in credit in exposed districts is driven by exposed MFIs, not unexposed MFIs, provides further support for the identification strategy.

3.3. Pretrend Analysis. As a further test of our identification strategy, Figure 2 shows event-study figures for our key outcomes, presenting estimates from the equation

$$
y_{i d t}=\alpha+\delta_{t}+\delta_{d}+\sum_{\tau=60, \tau \neq 66}^{\tau=68} \beta_{\tau} \times \text { Exposure }_{d} \times \mathbf{I}[t=\tau]+X_{i d t}^{\prime} \gamma+\varepsilon_{i d t}
$$

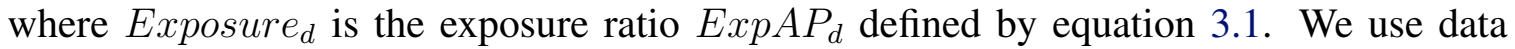
from NSS rounds 60, 61, 62, 64, 66 and 68. NSS round 66, on the eve of the AP crisis, is the base time period.

If the AP crisis led to an exogenous shock to credit availability in exposed districts, we should see no systematic difference in more- vs. less-exposed districts prior to the crisis, that is, before round 66. Changes in outcomes in more- vs. less-exposed districts after the AP crisis are then the causal effects of indirect exposure to the crisis. Panel A shows the evolution of consumption. In NSS rounds 60, 62 and 64, collected prior to the AP crisis, there is no systematic difference in the evolution of consumption in more- vs. less-exposed districts. Panel B shows that consumption of durables shows the same pattern. Likewise, 
in Panel C, we examine total earnings, which are not evolving differently in more- vs. lessexposed districts prior to the crisis. In Panels D, E and F we examine, respectively, overall casual wages, agricultural wages, and non-agricultural wages. For these outcomes, too, there is no pre-crisis difference between more- vs. less-exposed districts.

These figures also visually demonstrate our main results-we observe decreases in total and durable consumption, earnings, and wages in round 68, post-crisis.

\section{Results}

4.1. First Stage. The event-study figures already qualitatively demonstrate the key results. However, to improve precision and obtain quantitative estimates of the impact of the crisis, we next present estimates of the difference-in-difference specification (equation 3.2). For ease of interpretation, we normalize the exposure ratio $\operatorname{Exp} A P_{d}$ to have a unit standard deviation (SD) so that the coefficient on the Exposure Ratio is the effect associated with a1 SD change in exposure to the crisis, as measured by the pre-crisis portfolio-weighted exposure of the district's lenders to the AP crisis.

Column 1 of Table 3 presents the first stage, estimated by equation 3.2 with districtlevel gross loan portfolio per rural household as the dependent variable. Row 1 shows that those districts with an AP-exposed lender have INR 324 less credit outstanding from the reporting MFIs per rural household in 2012 (significant at 1\%). ${ }^{21}$ The second row of column 1 indicates that a 1 SD increase in exposure to the crisis is associated with INR 171 less credit outstanding from the reporting MFIs per rural household in 2012 (significant at $1 \%$ ), compared to other similar districts whose lenders were not exposed to the crisis. The regression results match the patterns shown in Panel B of Figure 1.

These effects imply that AP-exposed lenders cut back significantly on lending and this shortfall was not made up by other, non-exposed microlenders. It is not surprising that other microlenders were unable to target the borrowers of exposed MFIs. First, expanding to new villages requires fixed investments in branch infrastructure and in staff. Second, even non-exposed MFIs report having trouble obtaining credit from the Indian banking sector, which traditionally provided most of the funding to the MFIs, due to uncertainty in the aftermath of the AP Crisis. Third, borrowers often were allowed to take larger loans only after establishing a successful repayment record with their lenders. Given that there was no microfinance credit registry, even if households were able to secure new loans from new lenders, those loans would have been smaller in size.

\footnotetext{
${ }^{21}$ This corresponds to a reduction in microlending of roughly USD \$2 Million per exposed district.
} 
Representative Credit Data. Our proprietary credit data is not without limitations. In particular, it represents approximately $18 \%$ of the Indian market by loan volume: a number of MFIs declined to share their data with us. This presents a potential difficulty when comparing the reduced form estimates based on a representative sample of Indian households with the first-stage estimates which use only the responding subsample of MFIs. The impact of the sample selection depends on the correlation between the lending footprints of reporting and non-reporting lenders. For example, if exposed lenders tend to have correlated geographical footprints, then our first stage is likely to be too small, while the reduced form is relatively unaffected, leading to an overestimate of the TOT. ${ }^{22}$ If, on the other hand, there is no correlation between the footprints of responding and non-responding MFIs, then this will introduce classical measurement error into our measure of exposure which will then "wash out" of implied TOT calculations which scale the reduced form by the first stage. Consistent with the idea that the footprints of responding and non-responding MFIs are likely to be correlated, we observe that exposed districts are closer to Andhra Pradesh in Table C. $1 .^{23}$

Given that the MFI balance sheet data does not capture the entire market, we instead construct our preferred measure of household microfinance borrowing from the NSS 70th round "Debt and Investment" survey, which measures a household's total credit outstanding on June 30, 2012. This is an entirely different data source than that used in column 1 of Table 3. It is reported by households, not MFIs, and covers a nationally representative sample of Indian households. However, the "Debt and Investment" data is not without its own drawbacks: most significantly, we only have this data for one point in time, 2012, so we are unable to use a differences-in-differences empirical strategy. We must instead rely on cross-sectional comparisons, controlling for district-level, pre-crisis characteristics calculated from other data sources. ${ }^{24}$

\footnotetext{
${ }^{22}$ To see this, imagine that the footprints of the exposed MFIs we do observe are perfectly predictive of the exposed MFIs we do not observe, and similarly for the unexposed MFIs. Then our exposure instrument, Exposure $_{d}$ is measured without error-recall that the exposure measure is in percent of total pre-crisis GLP, not in rupees. In this case the reduced form regressions will yield unbiased estimates of the true effect. However, the measured first stage will be too small, by a factor $p$ which represents the share of total GLP represented by the MFIs whose balance sheets we observe. If the footprints of exposed and unexposed MFIs are positively but imperfectly correlated, similar reasoning applies.

${ }^{23}$ One common expansion strategy for MFIs is to open new branches close to existing operations, which we document in Appendix Table C.18.

${ }^{24}$ The NSS collected a small household indebtedness survey as a part of Round 66. However, the module was given only to landless agricultural households, and cannot adequately capture district-level microloan access.
} 
The "Debt and Investment" survey asks households to enumerate each loan outstanding and aims to capture the lender's regulatory classification (from 17 options). The NSS handbook (NSSO, 2014) states that for-profit microfinance should be grouped as SHG-NBFC (self-help group - non-banking financial company); however, non-profit microfinance and bank-linked SHGs are grouped under SHG-BL (self-help group - bank-linked). Further, there are three other categories that describe non-bank formal loans from financial institutions, which can be collateralized or uncollateralized. In sum, there is uncertainty about how respondents and surveyors would choose to treat a MFI loan. ${ }^{25}$ Because microloans are almost always uncollateralized, we capture microcredit with a measure that captures all uncollateralized non-bank credit from formal institutions, including non-collateralized SHG loans, some of which may be linked to a bank. Importantly, this definition allows us to capture impacts on microcredit that are net of any offsetting SHG supply response.

Columns 2-7 of Table 3 present OLS regressions of household credit on our pre-crisis AP exposure variables. Because we cannot use our differences-in-differences strategy, we instead control for numerous pre-crisis, district-level covariates. ${ }^{26}$ In columns 2 and 5, we examine the impacts of exposure to the crisis on the level of microcredit. The binary measure of pre-crisis exposure is associated with a reduction outstanding credit in 2012 of Rs. 1,297, significant at the $1 \%$ level. This represents a fall of roughly $50 \%$ of the control mean of INR 2395. Column 5, using the log of MFI credit outstanding, shows a similar result, a drop of $63 \log$ points in exposed districts. Note that the first stage using this representative borrowing data does indeed provide an estimate that is larger in magnitude that what we obtain using the data constructed from the sample MFIs. This is consistent with correlated geographical footprints of MFIs we discuss below in section 5.1. ${ }^{27}$

In the remaining columns, we present bank credit (cols 3 and 6) and total credit (cols 4 and 7) as outcomes. While the coefficients are estimated somewhat imprecisely, we find, in columns 3 and 6, no evidence that bank credit increased and thereby offset the fall in microcredit. (This finding is consistent with Appendix Table C.2, which uses a different source of data, namely RBI data on banks' balance sheets.) In column 4, we observe a large negative, but imprecisely measured, coefficient on total credit outstanding, suggesting that,

\footnotetext{
${ }^{25}$ Our experience in the field suggests that these differences in legal structure of loans-e.g., whether an MFI lender is for-profit or non-profit — are not always salient to respondents.

${ }^{26}$ MFI balance sheet controls include levels and quintiles of GLP measured in 2008 and 2010. RBI controls include amount of credit outstanding and number of accounts for agricultural loans, direct loans, and indirect loans. NSS 66 controls include average monthly household expenditures, annual durables expenditures, weekly earnings from and days worked in self-employment and non-self employment, daily wage, and percent of weekly earnings from self-employment.

${ }^{27}$ These results, which use a measure of microcredit that includes SHG loans, also demonstrate that SHGs did not in fact fill the void left by reduced access to microcredit loans.
} 
as expected given the aggregate nature of the shock, other sources such as informal lending could not compensate for the loss of microcredit. In Column 7, where we use the log of total credit outstanding, we observe a $77 \log$ point decline in total credit for exposed vs. unexposed districts, significant at the $5 \%$ level. $^{28,29}$

We conduct an additional exercise to probe the issue of partial MFI reporting. Specifically, we construct an alternative measure of our instrument, including all MFIN member MFIs, using predicted lending footprints for those MFIs that are not in our main dataset. We discuss this in Section 5.1.

Importantly, the fact that this was a microfinance shock matters for aggregate outcomes, over and above its impact on total district-level credit. The propagation of a credit supply shock will depend critically on the uses to which the credit would have been put, and microcredit serves specific needs, namely accelerating lumpy consumption and financing business investment, that are not well met by other sources. Moreover, the significant negative effects seen in columns 5 and 7 using the log transformation, which gives greater weight to the left tail of the distribution, indicates that credit particularly fell for poor households, who were most reliant on microcredit and likely least able to replace it with bank credit or other financing strategies such as drawing down assets.

Khwaja and Mian (2008) exercise. As an additional check on the first stage, we conduct an exercise exploiting within-district variation, modeled after Khwaja and Mian (2008). We focus on districts with both exposed and unexposed MFIs, and show that the fall in credit is driven by exposed MFIs. This also serves as an additional test of the identifying assumption that exposed and unexposed districts would have had similar counterfactual outcomes in the absence of the crisis: if exposed districts differed in some unobservable way, or suffered a demand shock due to being exposed to the AP crisis via other channels, we would expect unexposed lenders' portfolios to fall in those districts as well.

We examine this relationship via the following regression:

$$
\Delta y_{l d 12-10}=\alpha+\delta_{d}+\beta \times \text { Exposure }_{l} \times \text { Post }_{t}+X_{l d}^{\prime} \gamma+\varepsilon_{i d t}
$$

\footnotetext{
${ }^{28}$ In Appendix Table C.4 we present a measure based on the narrow NSS definition, those classified as SHGNBFC. As expected, the estimated impacts are smaller, consistent with widespread misclassification of MFI loans into other categories in the survey. Nonetheless, the results are negative and significant at the $10 \%$ level in both level and log specifications, using both the binary and continuous measures of exposure.

${ }^{29}$ Neither the NSS nor RBI data allows us to examine impacts on informal lending; however, the results in Table 3, discussed below, show that the effect on total lending is negative and large, albeit imprecisely estimated, so there is no evidence that informal lending filled the gap; this is intuitive since the credit shock was aggregate to districts, so the social networks of affected households were themselves affected.
} 
where $\Delta y_{l d 12-10}$ is the change in per rural household GLP lent by MFI $l$ to district $d$ between September 2010 and March 2012. The $\delta_{d}$ are district fixed effects, and Exposure $e_{l}$ is the exposure of lender $l$ to the AP crisis, measured by either the share of its portfolio in Andhra Pradesh as of September 2010, or a dummy equal to one if the MFI operated in Andhra Pradesh in September 2010.

Appendix table C. 3 shows the results. Column 1 shows that moving from 0 to $100 \%$ exposure of the MFI, captured by the share of its portfolio in Andhra Pradesh as of September 2010, is associated with a INR 281 fall in GLP per rural household over 2010 to 2012. The constant reflects any excess change GLP for an unexposed MFI in a district where some MFIs were exposed; it is very small and not significantly different from zero, demonstrating that unexposed MFIs in exposed districts do not show a change in lending compared with similar MFIs in unexposed districts. Column 2 uses an exposure dummy equal to one if the MFI operated in Andhra Pradesh on the eve of the crisis. Exposed MFIs saw an average decline in GLP per rural household of INR 153; again, the constant shows that unexposed MFIs saw no excess change. This supports the idea that exposure is identifying the effect of reduced credit supply from affected lenders, not an unobservable correlated with exposure which would affect unexposed lenders as well. Columns 3 and 4 show that controlling for MFI size (so that size is not proxying for exposure) does not change the results. ${ }^{30}$

\subsection{Reduced Form Results.}

Labor Outcomes. We begin by examining how the reduction in district-level credit access observed in Table 3 affects the local labor market. Table 4 reports treatment effects on casual daily wages, household total labor supply, total labor earnings, involuntary unemployment and entrepreneurship. We begin by noting that the reduction in credit did have economically and statistically significant effects on the casual daily wage. Exposed districts experienced a fall in the daily wage of INR 6.4, significant at the 5\% level, which is displayed in row 1 of column 1 . This represents roughly a $4 \%$ reduction from the unexposed district mean of INR 153. We next ask if this decrease in wage affected total household labor supply and total labor earnings. Column 2 shows that there are no detectable effects on total days worked (i.e., in self-employment and wage employment combined). However, column 3 shows that household days worked in casual daily wage labor did decrease by almost half a day on a base of 3.5 person days, demonstrating a substitution away from paid casual labor and toward self-employment).

\footnotetext{
${ }^{30}$ Note that the constant no longer has the same interpretation as it reflects the average positive growth rate of an MFI that was very small in 2010.
} 
Given that wages and paid days worked both fell, there is an overall decline in household weekly labor market earnings of INR 86 in exposed relative to unexposed districts after the AP crisis, significant at the $1 \%$ level (column 4). The significant effects on wages and labor earnings echo the predictions of Buera et al. (2017) and highlight the importance of incorporating general equilibrium effects into the analysis of the effects of credit access. Consistent with the null effect on total employment, we also observe that households do not change their assessment of whether they are involuntarily unemployed differentially in high versus low exposure districts after the crisis (column 5).

Column 6 examines effects on the likelihood that a household has a business which employs others. The point estimate on the extensive margin of being an employer is negative, but not significant at conventional levels $(p=.199)$ for the binary indicator; for the continuous measure of exposure we observed a fall of 0.3 percentage points, significant at the $10 \%$ level. This represents a fall of roughly $9 \%$ of the mean in unexposed districts. Of course, the businesses we capture in this measure are likely only a small fraction of total labor demand, as many businesses will not be owned by rural households; the data also do not allow us to examine the intensive margin of labor demand. However, these businesses are likely more representative of those operated by microfinance borrowers.

Finally, we consider how household self-employment activities respond to the labor market shock stemming from the fall in credit. In column 7, we show that households are more likely to report having a household enterprise in districts that are more exposed to the crisis. A one standard-deviation increase in exposure (row 2) corresponds to a 1.3 percentage point increase in the likelihood a household operates a business, significant at the $10 \%$ level. An increase in self-employment days is also consistent with the fact that we observe total worker days (column 1) falling by less than days worked in casual wage labor (column 3 ). This is consistent with the finding that self-employment can function as an employer of last resort and potentially represent masked un- or under-employment (Breza et al., 2020; Karaivanov and Yindok, 2017; Adhvaryu et al., 2013). The opposite signs of impacts in columns 6 and 7 is also consistent with other work documenting high levels of heterogeneity in firm profitability in developing country settings (Meager, 2019; Hussam et al., 2020). While some firms face binding credit constraints and fit the narrative of the investment channel, other firms have limited growth potential and function more as an insurance policy against negative shocks to earnings.

Impacts on Tradable and Non-tradable Sectors. We next consider the effect of the AP crisis-induced credit crunch on wages, separately for agriculture (tradable) and non-agriculture (non-tradable). Recall that, while the tradable sector should not be affected by changes to 
local demand, responding only to effects on firm liquidity, the non-tradable sector will be hit by both the local aggregate demand channel and the firm liquidity channel and, hence, may exhibit larger falls in wages.

Table 5 presents the results, estimated via a version of equation 3.2 which separately estimates the effect of exposure for the agricultural and non-agricultural sectors. The top panel of the table uses the binary measure of exposure, while the bottom panel uses the continuous measure. Column 1 uses observations of wages earned by both men and women. We find negative effects on the wage in both the tradable and non-trabable sectors, but the wage effects are larger for non-agricultural work. In the top panel, the wage drop associated with the binary measure of exposure is INR $5.08(p=0.128)$ for the agricultural sector, and INR 9.44 (significant at 5\%) for the non-agricultural sector. (The $p$-value of the test of the hypothesis that the effects are the same is 0.304.) While the average level of agricultural wages is lower, the effect on the non-agricultural wage is also larger in percentage terms: it falls by $5.12 \%$ of the control mean, compared with $3.95 \%$ for the agricultural wage. In the bottom panel we find similar results using the continuous measure of exposure, with a one unit increase in exposure associated with a 2.34 fall in the agricultural wage (not significant at conventional levels) and a fall of 5.32 in the non-agricultural wage (significant at 5\%); the $p$-value of the test of the hypothesis that the effects are the same is 0.155 .

Column 2 shows effects on men's wages, which may be less affected by the margin of whether to work for a wage. As in the results pooling genders, the wage effects are stronger for non-agricultural work. The fall in the wage associated with a one unit increase in exposure is roughly 3 times larger for the non-agricultural sector than the agricultural sector: 5.072 vs. 1.737 . The $p$-value of the test of the hypothesis that the effects are the same is 0.150 . Columns 3 and 4 repeat the analysis, winsorizing the wage data at the 99th percentile; the results are quite similar.

This pattern of results is consistent with the predicted impacts of a negative shock to labor demand through the business investment channel, affecting both tradables and nontradables, combined with a reduction in aggregate demand putting additional downward pressure on employment and wages in the non-tradable sector.

Consumption. Reduced access to credit may also affect household consumption, both through the falls in wages and earnings discussed above, and through a reduced ability to bring consumption forward in time via borrowing. ${ }^{31}$ Table 6 reports effects on total expenditure and

\footnotetext{
${ }^{31}$ Recall that the NSS data is collected contemporaneously with the credit shock and thus can pick up the direct effect on consumption resulting from reduced ability to move consumption over time. This is in contrast to many studies of microfinance where consumption and other outcomes are measured 12 or more months after the change in credit access, by which time the direct effect on consumption is likely to have passed.
} 
its components: nondurables and durables, measured on a monthly basis. Column 1, row 2 shows that a 1 standard deviation increase in exposure to the crisis is associated with a reduction of INR 151 in per household monthly total expenditures in 2012 (significant at $1 \%$ ). Column 2 examines per household monthly nondurable expenditures. Row 2 shows that a $1 \mathrm{SD}$ increase in exposure to the crisis is associated with a reduction of INR 128 (significant at 1\%). Column 3 repeats the analysis for per household monthly durable expenditures. Row 2 shows that a 1 SD increase in exposure to the crisis is associated with a reduction of INR 17 (significant at 5\%). In sum, reduced credit access resulted in reduced total consumption, stemming from falls in both nondurables and durables. In column 4, we also examine whether exposure to the crisis has any effect on whether households are below the poverty line. We find no significant effect on poverty, suggesting that the reduction in consumption is concentrated higher up in the distribution. ${ }^{32}$

Unfortunately, the NSS consumption module does not include any information on whether purchases were used for investment purposes. However, the NSS Round 70 survey contains data on household and business investment during the six-month period beginning on July 1, 2012. Given that we only have cross-sectional information on investment, we follow the same empirical strategy as in Table 3 cols 2-7, and control for a range of baseline district-level borrowing, consumption and earnings measures. Table 7 presents the results. We find significant declines in total investment (column 1), with the largest component coming from home construction and home improvements (column 2). The home improvement impacts are consistent with an aggregate demand channel, as most construction inputs are non-tradable. A large impact of home repair is also documented in Kaboski and Townsend (2012). Consistent with a business investment channel, we find negative impacts on both agricultural and non-agricultural business expenditures (columns 3-4). While the impacts on agricultural business expenditures are not statistically significant, a one standard-deviation in district exposure to Andhra Pradesh corresponds to a Rs. 39 fall in non-farm business investment, a drop of almost $20 \%$ relative to the unexposed district mean. These impacts are consistent with our interpretation of the findings in Table 4; overall business investment and hiring falls, despite an increase in self-employment.

Note that unlike our main measures of consumption, the investment outcomes can be matched to microfinance borrowing for the same set of households. In Appendix Section C.6, we investigate the extent to which the observed declines in investment are attributable

\footnotetext{
${ }^{32}$ Poverty headcounts in India have fallen substantially since the banking reform studied by Burgess and Pande (2005). During the timeframe of their study, $48 \%$ of rural households were classified as below the poverty line. In our data from 2010 , the poverty rate is only half as large, at $25 \%$. See Appendix D for details on the construction of the below poverty line variable.
} 
to the same households that experienced a decline in microfinance credit supply. We use a random forest model to classify households into likely borrowers and non-borrowers, based on household demographics. We then show that the overall investment results are substantially larger for likely borrowers, largely due to home improvement expenditures. We find significant impacts on non-agricultural business investment for non-borrowers and borrowers alike, which is consistent with broader equilibrium impacts.

Impacts on Agricultural Output. We next examine district-level impacts of the credit supply shock on output in the tradable (agricultural) sector. While tradables experience no shock to product demand, the effect on total output is unsigned. On one hand, agricultural firms will benefit from lower wage bills, but on the other hand, some of these farms may be forced to scale back as liquidity constraints bind more tightly.

We examine district-level crop yields to shed light on this question. (Given the importance of agriculture to rural Indian economies, effects of microfinance on crop yields are also of independent interest.) We use data from the Ministry of Agriculture, Directorate of Economics and Statistics, which collects information on crop production. Following Jayachandran (2006), we consider a weighted average of log yield (production in tonnes per area cropped) for the five major crops: rice, wheat, sugar, jowar (sorghum), and groundnuts. ${ }^{33}$ We also consider each crop separately. The results appear in Appendix Table C.5. We find a fairly precise zero effect for the index and for all crops but sugarcane, where the effect is less precise but still insignificant. This suggests that for the agricultural sector, the benefit from the wage reduction cancels out the cost from tighter liquidity constraints.

4.3. Scaling the Reduced Form Treatment Effects. Due to the limitations of both our pre-crisis measure of exposure and with our ex post measure of the drop in credit, one needs to use caution when thinking about scaling the reduced form, intent-to-treat (ITT) effects into treatment on the treated (TOT) effects. One issue, discussed above, is that the first stage based on the balance sheet data, as used in column 1 of Table 3, only measures lending from the subsample of MFIs who provided their data, while the reduced form regressions using the NSS are based on a representative sample of households. For this reason we consider the effect on MFI borrowing from the "Debt and Investment" data (Table 3, columns 2 and 5) to be the most appropriate measure of the total impact of the crisis on households' access to credit. Thus, if a first stage number is desired for scaling purposes, our preferred

\footnotetext{
${ }^{33}$ As in Jayachandran (2006), the weights are the district-average revenue share of the crop.
} 
specification is from Table 3, column 2, row 2 (Rs. -625.7). This implies a back-of-theenvelope multiplier on total consumption of 2.9. ${ }^{34,35}$ In section 5.2, we discuss this number in the context of other comparable consumption multipliers from the literature.

\subsection{Robustness.}

Urban markets. To give context for the magnitude of our results on rural markets, we examine the NSS data on urban areas. (Recall that all of the other analysis in this paper focuses on areas classified as rural by the NSS.) The microfinance shock should be much smaller in urban areas, due to deeper credit markets, less microfinance per capita, and more labor- and product-market integration.

One challenge with analyzing the "urban" subsample is that this classification can encompass areas ranging from small market towns to large metropolises. ${ }^{36}$ Thus, from the perspective of market integration and depth of credit access, some "urban" areas will actually be rural. Therefore, we split urban areas into those located in districts which are less than $100 \mathrm{~km}$ from the state capital, typically the largest city in the state, vs those in districts which are more than $100 \mathrm{~km}$ from the state capital. These more distant urban areas are likely to be less integrated, and are more often small market towns. For each of these urban subsamples, we examine the effect of exposure to the AP crisis on consumption, labor earnings, and wages (total and non-agricultural). The results are shown in Table 9.

Consistent with this prediction, we show that, in urban areas close to state capital cities, exposure to the AP crisis did not cause consumption, wages, or labor earnings to fall (Table 9, Panel A). As shown in Panel B, among the "urban" sample, only small market towns experienced the negative effects of the credit crunch; in these areas the effects are similar to those in the rural sample. In other words, while the effects of the credit contraction were significant for rural markets, this is not the case in more urban areas. Thus it may be especially important to consider equilibrium effects in less integrated markets, as found for price effects in Mexican villages by Cunha et al. (2019).

We next provide evidence to rule out several key threats to identification.

\footnotetext{
${ }^{34}$ This is obtained by annualizing the monthly consumption impact in Table $6,12 * 151=1812$, and dividing it by the change in credit ( -626.5$)$, yiedling a fall in consumption of Rs. 2.9 per rupee of lost credit.

${ }^{35}$ Recall that our exposure measure is also only based on a subset of MFIs. So this means that our reduced form and preferred first stage results are likely attenuated, but in the same way. Thus, the "back-of-theenvelope IV" is not subject to attenuation bias from measurement error.

${ }^{36}$ The NSS definition of an urban area typically requires that an area have (i) a minimum population of 5000, (ii) at least 75 percent of the male working population are non-agriculturists, and (iii) a density of population of at least (400 per sq. km.), but even areas which do not meet all three of these criteria can be classified as urban (NSSO, 2001). Moreover, urban observations are only tagged to the district, with no indicator for town/city name or population.
} 
Geographical Distance to AP. Recall from Table C.1 that exposure to the AP crisis is correlated with distance to Andhra Pradesh. While all of our regression specifications control for distance to AP interacted with time, it is also conceivable that the direct fallout of the AP crisis could have "spilled over" onto nearby districts through channels other than the MFI balance sheet effect we measure (e.g., economic uncertainty, decreased trade, etc.). We perform several tests to check that our results are not simply capturing such an effect.

In Table 8, we conduct two additional robustness exercises using alternate measures of distance to Andhra Pradesh. First, in Panel A, we rerun our main specification for key consumption and labor supply outcomes, ${ }^{37}$ but drop districts with a geographical border with Andhra Pradesh. Second, because raw geographical distance may not adequately capture some types of relationships between districts, such as trade costs, due to variation in the quality of infrastructure, in Panel B we add the travel time between a given district and Hyderabad, as measured in Allen and Atkin (2016), interacted with time. Across these iterations, the results look very similar to those in our main specification.

Finally, we also conduct Altonji-type tests in Appendix Table C.7, systematically dropping each state from the analysis. We find that no single state is driving the results, including those bordering AP.

Additional robustness. Our results are robust to a battery of robustness checks. We assign placebo shocks to alternate time periods; we examine placebo shocks (using randomization inference to re-assign exposure to the crisis across districts and examining placebo exposure to states other than Andhra Pradesh); we include time-varying controls for SHG penetration and political affiliation to proxy for risks of policy contagion; we include additional timevarying controls for initial economic conditions and rainfall; and we explore the robustness of our findings to inter-district migration. Additionally we perform several checks to ensure that our results are not sensitive to our treatment of the tails of the data, nor to concerns of multiple inference. Details are in Appendix B.

\section{INTERPRETATION}

5.1. Alternate Exposure Measure using Predicted MFI Locations. As we discuss above, our measure of exposure is based on those MFIs that voluntarily contributed their lending data. But how consequential is this selected sample for our results? We use the richness of our MFI data, combined with other publicly-available data sources, to predict the geographical footprints of the non-reporting MFIs. These predicted lending locations allow us

${ }^{37}$ These are total consumption, durable consumption, weekly labor earnings, weekly casual days worked, and the casual daily wage. 
to recompute our exposure measures, but for the full set of lenders. See Appendix Section C.5 for further details.

Our first step is to use logistic regression to construct a mapping from publicly-available covariates into location decisions. We consider functions of distance to headquarters and lagged total portfolio size as predictors. The results are presented in Appendix Table C.18 and confirm that, as discussed above, MFI decisions are highly correlated with distance from headquarters. Moreover, as MFIs grow, their footprints expand, and the correlation with distance becomes less pronounced.

We are able to measure the logit predictors for most of the non-reporting MFIs, allowing us to predict their lending locations and construct an alternate measure of predicted exposure to the crisis. We follow a similar procedure to that described in Section 3.1, but use a predicted indicator for whether each MFI has active loans in each district, rather than a continuous measure. For the MFIs that reported to us, we use the actual locations. ${ }^{38}$

Table C.19 shows a summary of the first stage and reduced form results using the predicted exposure instrument. The results are qualitatively similar to the prior analysis, albeit noisier in some places. The size of the implied consumption multiplier is also similar in magnitude. This exercise offers further evidence that our results are not an artefact of observing the district-level balance sheets of only some lenders. Because AP-exposed lenders tend to lend in other similar places, our exposure measure based on only reporting MFIs is similar to a measure which also incorporates non-reporting MFIs.

5.2. GE Effects in the Development Literature. To help benchmark our results, Table 10 presents the findings of five recent GE studies in the development economics literature. The most relevant point of comparison is Egger et al. (2019), which analyzes a large RCT that randomized cash transfers to rural communities in Kenya. Notably, these transfers were large - worth $17 \%$ of local GDP - and the randomization design permits analysis of equilibrium impacts at a local market level (e.g., at a radius of $2 \mathrm{~km}$ around each village). There, the authors calculate a fiscal multiplier of 2.7 .

We may expect multipliers from loans to be different than multipliers from grants. Because, by definition, those taking loans are choosing to bring resources forward in time, this implies that their marginal utility of funds today exceeds the marginal utility of funds in the future. This would lead to larger multiplier impacts from loans versus cash transfers. Moreover, relative to Egger et al. (2019), we study variation at the much larger, district

\footnotetext{
${ }^{38}$ The correlation between the continuous measure used in the preceding analysis and the predicted exposure measure is 0.72 .
} 
level, which likely allows us to capture more of the possible spillover effects from the intervention. We find a back of the envelope consumption multiplier of 2.9, in our setting.

Two of the papers in Table 10, Burgess and Pande (2005) and Kaboski and Townsend (2012) measure the change in the wage in response to an increase in access to finance. Burgess and Pande (2005) study the coordinated expansion of rural bank branches in India and find a $7 \%$ agricultural wage increase from one additional branch per 100,000 people. Kaboski and Townsend (2012) find a comparable agricultural wage response to a $43 \%$ increase in short term credit stemming from an increase in rural credit supply. ${ }^{39}$

The table also highlights two studies of the impacts of a change in labor demand. Imbert and Papp (2015) show that agricultural wages increase by $4.7 \%$ as a result of a $1.3 \%$ demand shift from India's public works program (NREGA). Muralidharan et al. (2017) improve the functioning of NREGA through digitization and cause a $6 \%$ increase in NREGA demand. This shift in labor demand is leads to a $6.1 \%$ increase in the wage. In Bangladesh, Akram et al. (2017) find a wage increase of 4.5-6.6\% in response to a $30 \%$ increase in temporary migration from rural villages. These results suggest that modest changes to labor demand can lead to substantial wage effects.

\section{Model CAlibration}

We calibrate a simple equilibrium model of microfinance borrowing that incorporates both aggregate demand and business investment impacts. We aim to understand whether the magnitudes of our empirical results are similar to those that emerge from such a model. Moreover, we can recalibrate the impacts on wages in the model by changing the propensity for microfinance borrowers to invest in profitable businesses. We provide details of the environment and calibrated parameters in Appendix E.

To summarize, we assume a two-period, two-sector economy with tradable and nontradable goods. Households are endowed with labor in each sector and supply their labor inelastically. In this way, labor markets are segmented. ${ }^{40}$ Some households are further endowed with the skill to become an entrepreneur in one of the sectors. If households choose entrepreneurship, then they cannot supply wage labor. They produce using labor, which they hire from each sector's labor market at the equilibrium wage. Households have preferences over consumption of goods in each sector. Households cannot save and are endowed with non-labor income in each period. We assume that this non-labor income is larger in

\footnotetext{
${ }^{39}$ Consistent with our results, Kaboski and Townsend (2012) find a much larger wage impact for jobs in construction, a non-tradable sector. They also find large short-run consumption effects which are consistent with an aggregate demand story.

${ }^{40}$ This could be driven, for example by skill requirements, especially in the non-tradable sector.
} 
the second period, giving households a motive to borrow. When available, microcredit can be used by eligible households who wish to bring consumption forward. We also vary the mass of constrained entrepreneurs who are able to take microloans to finance production.

Equilibrium occurs in both the labor and the product markets. In the tradable sector, prices are determined by global factors, outside of the economy. However, in the nontradable sector, consumer demand and producer supply must be equalized. Moreover, the wage in each sector equates labor supply with demand.

Of course, any exercise of this type requires us to make a number of assumptions. We view this calibration largely as a sanity check, showing that plausible parameter values can deliver wage effects in the range of our estimated magnitudes.

Calibrated Parameters of the model. We calibrate the parameters describing households' skilled and unskilled labor endowments and tradable and nontradable consumption shares using NSS data. Production function parameters (TFP and returns to scale) are chosen to match those for India in Buera et al. (2017). In the absence of more detailed sectoral information, and so as not to "bake in" differences between the two sectors, we assume the same production parameters for both tradable and non-tradable businesses. The credit market parameters are chosen to match the real interest rate charged by Indian microlenders, the size of a loan as a share of annual labor earnings, and the share of households who borrow from microfinance.

To generate calibrated treatment effects, we compare a simplified economy with status quo access to microfinance with an economy experiencing a credit supply contraction. We assume that credit supply contracts by $54 \%$, as we observe in our first stage in Table 3 . Because, in practice, exposed microlenders gave fewer loans of the same value, rather then smaller loans to all borrowers, we assume that the fraction of potential microfinance borrowers shrinks by $54 \%$, while the loan amounts conditional on borrowing stay the same relative to the pre-crisis status quo.

Calibration Results. We present the calibrated treatment effects on wages in the tradable and non-tradable sectors in Figure 3 and examine how they change with the share of microcredit borrowers who borrow for business investment. Recall that the estimated effects on sectoral wages using the binary exposure measure are a 3-4\% fall in the agricultural (tradable) wage and a 4-5\% fall in the non-agricultural (non-tradable) wage (see table 5). When approximately one third of microfinance is used for business investment, and the remainder is used for consumption, the wage effects implied by the calibrated model are in the range of our estimated impacts. The finding that roughly one-third of microfinance loans are used 
for businesses in the non-agricultural sector is consistent with Banerjee et al. (2020), who show that the top tercile of urban households experiences persistent and positive effects on business profitability and scale using variation from a microfinance RCT.

We note that there are unmodeled channels which could also contribute to the size of the empirical effects. A precautionary savings motive would amplify the aggregate demand effect as households save to re-build buffer stocks (Kaboski and Townsend, 2011). And a labor supply response would magnify the wage fall, as households respond to consumption drops by increasing labor supply (Jayachandran, 2006).

\section{CONCLUSION}

We use the Andhra Pradesh microfinance ordinance as a natural experiment to measure the real impacts of the loss of microfinance on rural households. Given the scale and maturity of the microfinance sector in India before the ordinance and the extent of the crisis, which wiped roughly a billion dollars off of lenders' balance sheets, this episode presents a unique opportunity to study the impacts of microfinance in general equilibrium.

We present evidence that our impacts are likely driven by a combination of two distinct channels, business investment and aggregate demand. Because we only have one instrument, we cannot empirically disentangle the separate contribution of each channel. Moreover, the two channels may interact in important ways. However, our results resonate with recent micro-evidence, suggesting heterogeneity in both the uses of and returns to microfinance (Banerjee et al., 2020, 2019; Kaboski and Townsend, 2011; Meager, 2019). The following narrative emerges: a sizable minority of households grow their businesses when microfinance expands, while the remaining borrowers consume the loan (or invest in home improvements or household durables). The former group's business spending and hiring drives the investment channel, and the latter group's consumption borrowing fuels an aggregate demand channel.

Our results also show that the actions of politicians in Andhra Pradesh had large negative externalities on microcredit supply to the rest of the country. Microfinance institutions were no longer able to finance creditworthy borrowers in other states, which in turn led to decreased wages, earnings and consumption. This episode shows that microfinance, despite its small loan sizes, can have meaningful impacts on rural economies.

Insofar as credit not borrowed today does not need to be repaid in the future, one might think that, over time, the net effect of the crisis will "wash out." However, for poor households, utility is likely quite concave and so the volatility in the credit market, which translates into volatility in wages, earnings, and consumption, may be quite costly. The loss 
in total welfare resulting from a pronounced short term consumption fall will not be fully offset by a future stream of slightly higher consumption. Moreover, some effects of the credit crunch could persist, due to, for instance, durable investment or adjustment costs.

Ultimately, we believe our findings complement the RCT literature. Randomized evidence has documented that microfinance has modest medium-term effects on borrowers relative to non-borrowers in the same area. By studying quasi-exogenous variation in credit supply at a higher level of aggregation, we find evidence of important equilibrium effects through changes to labor demand, effects which effect both borrowers and non-borrowers in affected markets. These results together can paint a more complete picture than either taken alone.

\section{REFERENCES}

(2010): "Rising suicides force AP ordinance to check microfinance firms - The Hindu," https://www.thehindu.com/business/ Rising-suicides-force-AP-ordinance-to-check-microfinance-firms/ article15780132. ece, (Accessed on 01/15/2020).

Adhvaryu, A., N. Kala, And A. Nyshadham (2013): "Booms, busts, and household enterprise: Evidence from coffee farmers in Tanzania," The World Bank Economic Review.

Ahlin, C. AND N. JiAng (2008): “Can micro-credit bring development?" Journal of Development Economics, 86, 1-21.

Akram, A. A., S. Chowdhury, AND A. M. Mobarak (2017): "Effects of Migration on Rural Labor Markets," NBER Working Paper No. 23929.

Allen, T. AND D. AtKin (2016): "Volatility and the Gains from Trade," NBER Working Paper, 22276.

Anderson, M. L. (2008): "Multiple inference and gender differences in the effects of early intervention: A reevaluation of the Abecedarian, Perry Preschool, and Early Training Projects," Journal of the American statistical Association, 103, 1481-1495.

Angelucci, M., D. Karlan, And J. Zinman (2015): "Microcredit Impacts: Evidence from a Randomized Microcredit Program Placement Experiment by Compartamos Banco," American Economic Journal: Applied Economics, 7, 151-82.

Attanasio, O., B. Augsburg, R. De Haas, E. Fitzsimons, and H. Harmgart (2015): "The Impacts of Microfinance: Evidence from Joint-Liability Lending in Mongolia," American Economic Journal: Applied Economics, 7, 90-122. 
Attanasio, O. And E. PAstorino (2020): "Nonlinear pricing in village economies," Econometrica, 88, 207-263.

Augsburg, B., R. De HaAs, H. Harmgart, and C. Meghir (2015): “The Impacts of Microcredit: Evidence from Bosnia and Herzegovina," American Economic Journal: Applied Economics, 7, 183-203.

Banerjee, A., E. Breza, E. Duflo, And C. Kinnan (2020): "Can microfinance unlock a poverty trap for some entrepreneurs?" National Bureau of Economic Research WP 26346.

Banerjee, A., E. Duflo, R. Glennerster, And C. Kinnan (2015a): “The Miracle of Microfinance? Evidence from a Randomized Evaluation," American Economic Journal: Applied Economics, 7, 22-53.

Banerjee, A., E. Duflo, And R. Hornbeck (2018): "How much do existing borrowers value Microfinance? Evidence from an experiment on bundling Microcredit and insurance," Economica, 85, 671-700.

BanerJee, A., D. KARlan, And J. ZinMAn (2015b): "Six Randomized Evaluations of Microcredit: Introduction and Further Steps," American Economic Journal: Applied Economics, 7, 1-21.

Banerjee, A. V., E. Breza, R. Townsend, And D. Vera-Cossio (2019): “Access to Credit and Productivity: Evidence from Thai Villages," Working Paper.

BanerJee, A. V. AND A. F. Newman (1993): "Occupational Choice and the Process of Development," Journal of Political Economy, 101, 274-298.

Beaman, L., D. Karlan, B. Thuysbaert, And C. Udry (2020): "Selection into Credit Markets: Evidence from Agriculture in Mali," Tech. rep.

Ben-Yishay, A., A. Fraker, R. Guiteras, G. Palloni, N. B. Shah, S. Shirrell, AND P. WANG (2017): "Microcredit and willingness to pay for environmental quality: Evidence from a randomized-controlled trial of finance for sanitation in rural Cambodia," Journal of Environmental Economics and Management, 86, 121-140.

BrezA, E., S. Kaur, AND Y. Shamdasani (2020): "Labor Rationing: A Revealed Preference Approach from Hiring Shocks," Working paper.

BuERA, F. J., J. P. KABOSKI, AND Y. SHIN (2017): “The macroeconomics of microfinance," Working Paper.

Burgess, R. And R. PAnde (2005): "Do Rural Banks Matter? Evidence from the Indian Social Banking Experiment," American Economic Review, 95, 780-795. 
Burke, M., L. F. Bergquist, And E. Miguel (2018): "Sell Low and Buy High: Arbitrage and Local Price Effects in Kenyan Markets," Tech. rep., National Bureau of Economic Research.

Bustos, P., G. Garber, And J. Ponticelli (2020): “Capital accumulation and structural transformation," The Quarterly Journal of Economics, 135, 1037-1094.

Chodorow-REICH, G. (2014): "The employment effects of credit market disruptions: Firm-level evidence from the 2008-9 financial crisis," The Quarterly Journal of Economics, 129, 1-59.

COLE, S. (2009): "Fixing market failures or fixing elections? Agricultural credit in India," American Economic Journal: Applied Economics, 1, 219-50.

Cole, S. AND Y. SAlEmAn (2015): "SKS and the AP Microfinance Crisis," Harvard Business School Case 9-212-018.

Crépon, B., F. Devoto, E. Duflo, And W. Parienté (2015): "Estimating the Impact of Microcredit on Those Who Take It Up: Evidence from a Randomized Experiment in Morocco," American Economic Journal: Applied Economics, 7, 123-50.

Cunha, J. M., G. De Giorgi, and S. Jayachandran (2019): "The price effects of cash versus in-kind transfers," The Review of Economic Studies, 86, 240-281.

Devoto, F., E. Duflo, P. Dupas, W. Parienté, And V. Pons (2012): "Happiness on tap: Piped water adoption in urban Morocco," American Economic Journal: Economic Policy, 4, 68-99.

Egger, D., J. Haushofer, E. Miguel, P. Niehaus, and M. W. Walker (2019): "General equilibrium effects of cash transfers: experimental evidence from Kenya," Tech. rep., National Bureau of Economic Research.

FINK, G., B. K. JACK, AND F. MASIYE (2020): "Seasonal Liquidity, Rural Labor Markets, and Agricultural Production," American Economic Review, 110, 3351-92.

Government of India Planning Commission (2014): "Report of the expert group to review the methodology for measurement of poverty," Tech. rep.

Greenstone, M., A. Mas, And H.-L. NGuyen (2014): "Do credit market shocks affect the real economy? Quasi-experimental evidence from the Great Recession and normal economic times," NBER Working Paper.

Hsieh, C.-T. AND B. A. Olken (2014): "The missing" missing middle"," Journal of Economic Perspectives, 28.

Huss AM, R., N. Rigol, And B. N. Roth (2020): “Targeting High Ability Entrepreneurs Using Community Information: Mechanism Design in the Field," Working Paper. 
IMBERT, C. AND J. PAPP (2015): "Labor market effects of social programs: Evidence from india's employment guarantee," American Economic Journal: Applied Economics, 7, 233-263.

JAYACHANDRAN, S. (2006): "Selling labor low: Wage responses to productivity shocks in developing countries," Journal of political Economy, 114, 538-575.

Jiménez, G., A. Mian, J.-L. Peydró, And J. SAurina (2014): “The Real Effects of the Bank Lending Channel,' Working Paper.

Johnson, D. AND S. MeKa (2012): “Access to Finance in Andhra Pradesh," SSRN Electronic Journal.

KABOSKI, J. P. AND R. M. TOWNSEND (2011): “A Structural Evaluation of a Large-Scale Quasi-Experimental Microfinance Initiative,” Econometrica, 79, 1357-1406.

- (2012): “The impact of credit on village economies," American economic journal. Applied economics, 4, 98.

KARAIVANOV, A. AND T. YINDOK (2017): "Involuntary Entrepreneurship: Evidence from Thai Urban Data," SFU Working Paper.

KhWAJA, A. I. AND A. Mian (2008): "Tracing the impact of bank liquidity shocks: Evidence from an emerging market," The American Economic Review, 1413-1442.

KINETZ, E. (2011): "Virtue of 'microfinance' turning to vice? - Washington Times," https://www.washingtontimes.com/news/2011/mar/10/ virtue-of-microfinance-turning-to-vice/, (Accessed on 01/15/2020).

MeAGer, R. (2019): "Understanding the Impact of Microcredit Expansions: A Bayesian Hierarchical Analysis of 7 Randomised Experiments," American Economic Journal: Applied Economics.

- (2020): "Aggregating distributional treatment effects: A Bayesian hierarchical analysis of the microcredit literature," Working Paper.

Mian, A. AND A. SUfi (2014): "What explains the 2007-2009 drop in employment?" Econometrica, 82, 2197-2223.

Mian, A. R., A. Sufi, And E. Verner (2017): "How Do Credit Supply Shocks Affect the Real Economy? Evidence from the United States in the 1980s," Working Paper.

Muralidharan, K., P. Niehaus, and S. Sukhtankar (2017): “General equilibrium effects of (improving) public employment programs: Experimental evidence from India," NBER WP 23838.

NSSO (2001): Concepts and Definitions Used in NSS, Government of India, New Delhi. (2014): Key Indicators of Debt and Investment in India, NSS 70th Round, Government of India, New Delhi. 
PARAVISINI, D. (2008): "Local bank financial constraints and firm access to external finance," The Journal of Finance, 63, 2161-2193.

PeEK, J. And E. S. Rosengren (2000): "Collateral damage: Effects of the Japanese bank crisis on real activity in the United States," American Economic Review, 30-45.

RAI, V. (2010): “India's Microfinance Crisis is a Battle to Monopolize the Poor," https : //hbr.org/2010/11/indias-microfinance-crisis-is, (Accessed on 01/15/2020).

RAO, S. (2010): "Crop loss: AP farmers commit suicide - India News," https://www.indiatoday.in/india/east/story/ freak-rains-turn-ap-into-a-graveyard-of-farmers-87392-2010-12-20, (Accessed on 01/15/2020).

RoOdmAN, D. (2010): "Backgrounder on India's Microfinance Crisis I Center For Global Development," https://www.cgdev.org/blog/ backgrounder-indias-microfinance-crisis, (Accessed on 01/15/2020).

SCHNABL, P. (2012): "The international transmission of bank liquidity shocks: Evidence from an emerging market," The Journal of Finance, 67, 897-932.

SRIRAM, M. S. (2012): "The AP Microfinance Crisis 2010: Discipline or Death?" Vikalpa, 37, 113-128.

TARozzi, A., J. Desai, And K. Johnson (2015): “The Impacts of Microcredit: Evidence from Ethiopia," American Economic Journal: Applied Economics, 7, 54-89.

Tarozzi, A., A. Mahajan, B. Blackburn, D. Kopf, L. Krishnan, and J. Yoong (2014): "Micro-loans, insecticide-treated bednets, and malaria: evidence from a randomized controlled trial in Orissa, India," The American Economic Review, 104, 1909-1941.

TAYLOR, M. (2011): “'Freedom from poverty is not for free': Rural development and the microfinance crisis in Andhra Pradesh, India," Journal of Agrarian Change, 11.

Yerramilli, P. (2012): "The Politics of the Microfinance Crises in Andhra Pradesh, India," Critical Quarterly, 54, 26-34. 


\section{FIGURES}

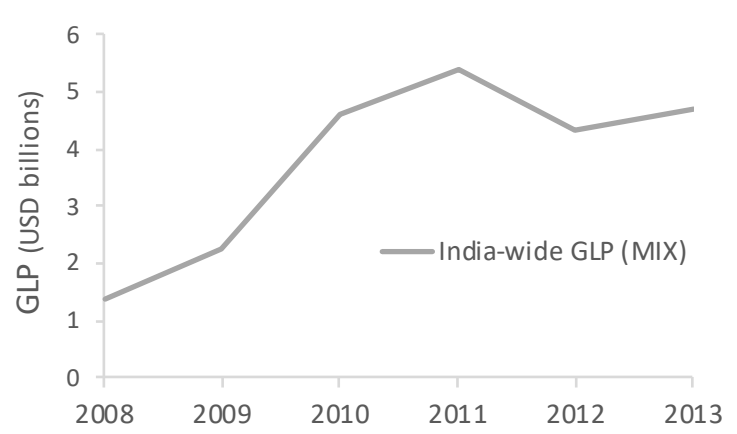

(A) Panel A: India-Wide GLP

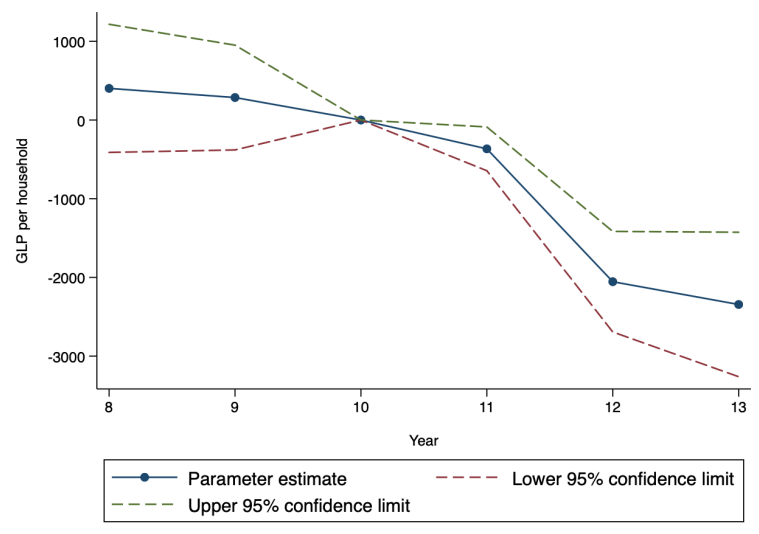

(B) Panel B: GLP in Exposed vs. Unexposed Districts

FiguRE 1. Growth of Microfinance Gross Loan Portfolio: India and Analysis Sample

Note: Panel A plots the India-wide gross loan portfolio (GLP) aggregated across microfinance institutions and states as reported in USD in the MIX database. Panel B shows the evolution of microfinance using the balance sheet data (reported in Indian rupees) from 25 microfinance institutions. The figure in Panel B uses the panel of data across all years reported to us by the participating MFIs. We restrict observations to districts with any microfinance loans outstanding in 2008. 


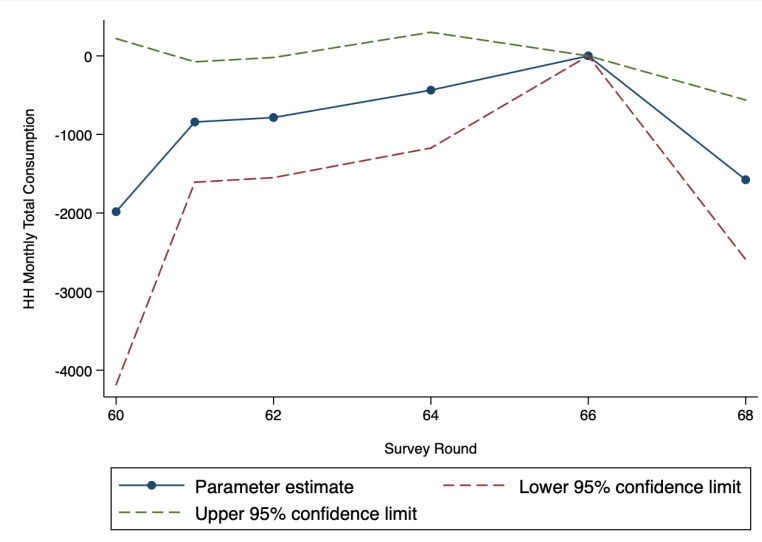

(A) Panel A: Total Consumption

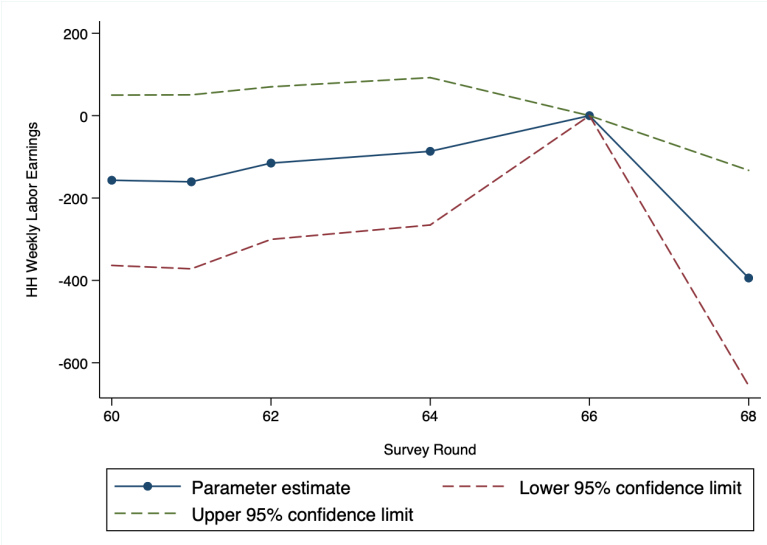

(C) Panel C: Total Earnings

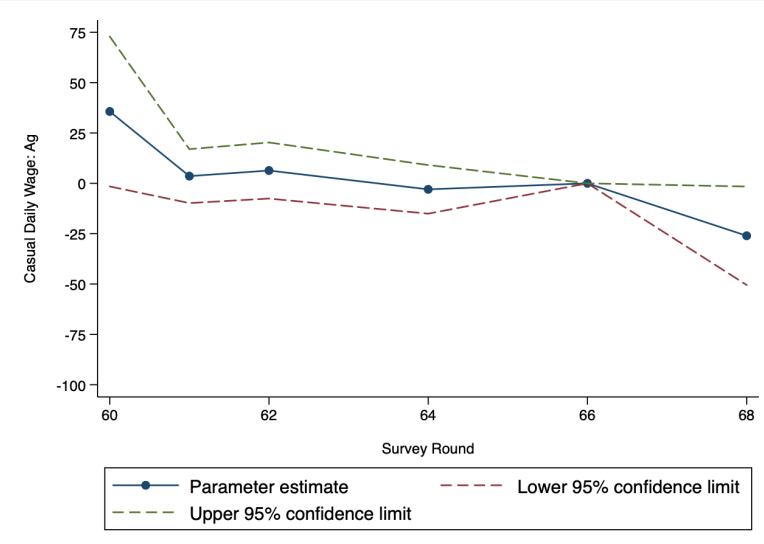

(E) Panel E: Ag Wages

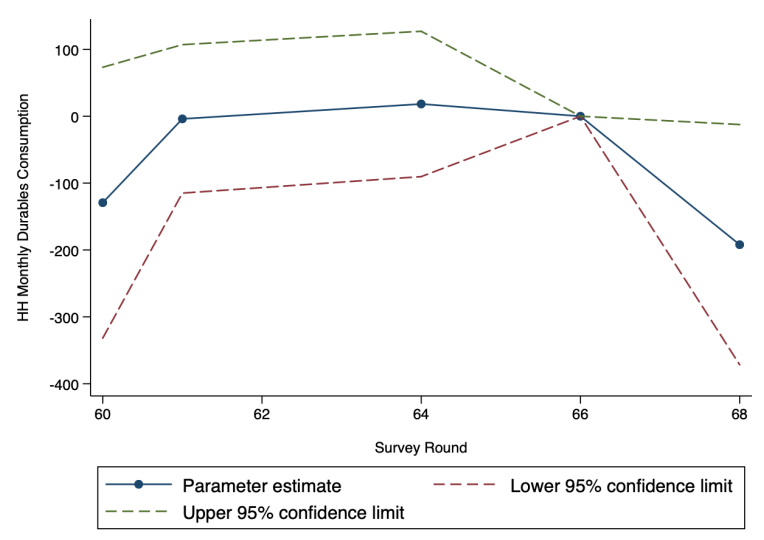

(B) Panel B: Durables Consumption

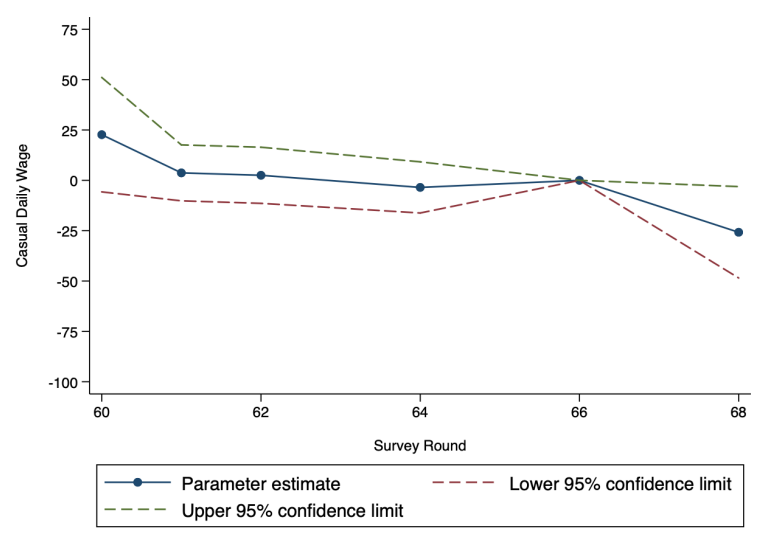

(D) Panel D: Average Wages

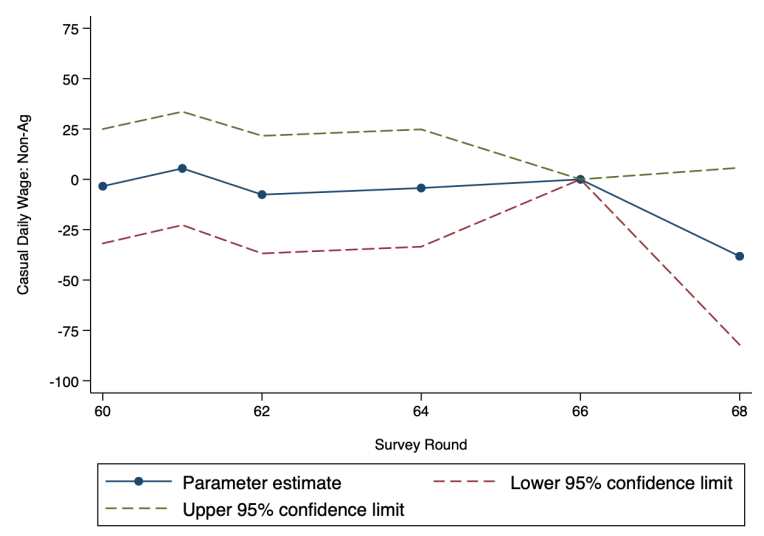

(F) Panel F:Non-Ag Wages

FIgure 2. Pretrends: Continuous Exposure Measure.

Note: Pretrend plots using data from NSS rounds 60,61, 62, 64, 66, and 68. The plotted estimates are year-specific coefficients from regressions of the outcome variable on the continuous exposure measure. Round 66 is the omitted category. Controls include round and district fixed effects, Round 66 average district consumption, average casual wage and linear distance to AP interacted with round, quintiles of household size, number of rural households and its squared term, GLP quintiles in 2008 and 2010 dummies along with round and survey month fixed effects. Wage and earnings are winsorized at the 99th percentile. Standard errors are clustered at the district level. Observations are weighted by NSS sampling weights. Durable consumption was not asked in NSS round 62. 


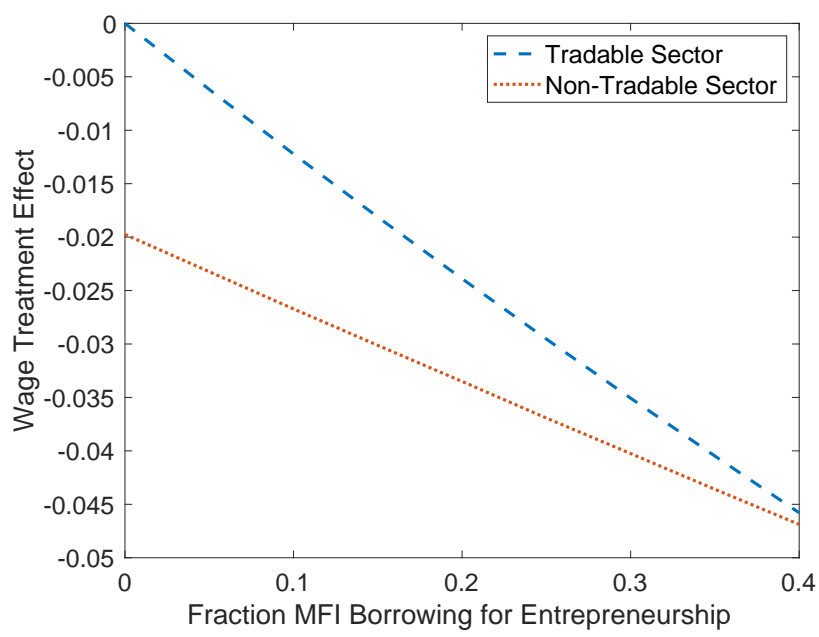

FIGURE 3. Calibrated Wage Effects by Share Borrowing for Entrepreneurship Note: The figure shows the percentage drops in the sector-specific wages resulting from a $54 \%$ decrease in access to credit in the calibrated model. The $x$-axis is the fraction of borrowers who borrow to invest in a business. For details and parameter values, see Section 6 and Appendix E. 


\section{TABLES}

TABLE 1. Sample Selection

\begin{tabular}{|c|c|c|c|c|c|c|}
\hline & $\begin{array}{c}\text { (1) } \\
\text { Average Loan } \\
\text { per Borrower }\end{array}$ & $\begin{array}{c}\text { (2) } \\
\text { Number of } \\
\text { Borrowers }\end{array}$ & $\begin{array}{c}\text { (3) } \\
\text { Borrowers per } \\
\text { Staff Member }\end{array}$ & $\begin{array}{c}(4) \\
\text { Write-off } \\
\text { Ratio } \\
\end{array}$ & $\begin{array}{c}(5) \\
\text { Portfolio at } \\
\text { Risk, 30 Days }\end{array}$ & $\begin{array}{l}\text { (6) } \\
\text { MFI } \\
\text { Age }\end{array}$ \\
\hline \multicolumn{7}{|c|}{ Panel A: Selection into the Sample } \\
\hline MFI in the Sample & $\begin{array}{l}-25.164 \\
(21.324)\end{array}$ & $\begin{array}{c}-34132.611 \\
(103178.714)\end{array}$ & $\begin{array}{c}-72.491 * * \\
(35.782)\end{array}$ & $\begin{array}{l}-0.002 \\
(0.002)\end{array}$ & $\begin{array}{c}-0.017 * * * \\
(0.006)\end{array}$ & \\
\hline Control mean & 176.064 & 245201.611 & 267.591 & 0.005 & 0.023 & \\
\hline Control SD & 198.024 & 782389.257 & 256.144 & 0.012 & 0.047 & \\
\hline Observations & 114 & 115 & 113 & 82 & 84 & \\
\hline \multicolumn{7}{|c|}{ Panel B: Sampled MFIs, relation to exposure } \\
\hline Exposure to AP & $\begin{array}{l}-0.750 \\
(8.776)\end{array}$ & $\begin{array}{c}166780.191 \\
(241593.920)\end{array}$ & $\begin{array}{c}72.574 \\
(56.126)\end{array}$ & $\begin{array}{l}-0.002 \\
(0.002)\end{array}$ & $\begin{array}{c}0.002 \\
(0.006)\end{array}$ & $\begin{array}{c}0.132 \\
(0.500)\end{array}$ \\
\hline Control mean & 152.000 & 177160.059 & 179.176 & 0.004 & 0.007 & 1.118 \\
\hline Control SD & 29.180 & 215349.208 & 103.882 & 0.005 & 0.007 & 0.993 \\
\hline Observations & 21 & 21 & 21 & 18 & 18 & 21 \\
\hline
\end{tabular}

Note: Data from the Microfinance Information Exchange (MIX). In panel A, the right-hand side variable is a dummy indicating if the institution is in our sample. In panel B, the right-hand side variable is a dummy indicating if the MFI was exposed to the AP crisis. Of the 25 MFIs in our sample, 21 report to MIX; these comprise the sample in Panel B. Write-off ratio and Portfolio at risk are fractions of the overall portfolio. The left-hand side variable in column (6) refers to the number of years before 2010 that the MFI reports positive GLP; it is a measure of age in 2010, top-censored at 2 years (2008). Since it is available only for sampled MFIs, this dependent variable is used only in Panel B. Robust standard errors in parentheses. 


\section{TABLE 2. Summary Statistics}

\begin{tabular}{lccc} 
Variable & Obs & Mean & Std. Dev \\
\hline & & & \\
Panel A: District-level variables from balance sheet data & & & \\
Any exposed lender (all districts) & 354 & 0.35 & 0.48 \\
Exposure ratio (all districts) & 354 & 0.08 & 0.13 \\
Exposure ratio (exposed districts) & 132 & 0.23 & 0.11 \\
Gross loan portfolio in lakhs (100,000 Rs., unexposed districts) & 222 & 1236.39 & 1819.80 \\
& & & \\
Panel B: Household-level variables from NSS (round 68) & & & \\
HH Weekly Labor Earnings & 16340 & 854.81 & 1434.83 \\
Casual Daily Wage: Ag & 1176 & 140.53 & 58.53 \\
Casual Daily Wage: Non-Ag & 2460 & 194.71 & 107.40 \\
HH Weekly Days Worked: Total & 16340 & 10.28 & 6.74 \\
Household weekly days worked in self-employment & 16340 & 6.55 & 7.04 \\
Household weekly days worked in non-self-employment & 16340 & 3.73 & 5.16 \\
Any HH Member Invol. Unemployment & 16340 & 0.10 & 0.30 \\
Any HH Member had NREGA Work this Week & 16340 & 0.02 & 0.13 \\
HH size & 16340 & 4.52 & 2.23 \\
Number of earners in HH & 16340 & 1.45 & 0.27 \\
HH Monthly Consumption: Total & 16340 & 5643.40 & 4531.70 \\
HH Monthly Consumption: Durables & 16340 & 382.25 & 1891.40 \\
Any non-Ag. Self Employment & 16340 & 0.22 & 0.41 \\
& & & \\
Panel C: Household-level variables from NSS (round 70) & & & \\
Uncollateralized formal non-bank amt outstanding, win & 15633 & 2412 & 13239 \\
Bank amt outstanding, win & 15633 & 29212 & 104144 \\
Total loan amt outstanding, win & 15633 & 52841 & 127636 \\
& & & \\
\hline
\end{tabular}

Note: Outcomes variables in Panel A are from the balance sheet data collected with MFIN; see text for details. Exposed (unexposed) districts are districts with any (no) exposed lender. Outcome variables in Panel B are from NSS round 68 (2012). Outcome variables in Panel C are from NSS round 70 (2014). Household borrowing data in Panel C are winsorized at the 99th percentile. 
TABLE 3. Exposure to the AP Crisis and total MFI lending

\begin{tabular}{|c|c|c|c|c|c|c|c|}
\hline & $\begin{array}{c}\text { (1) } \\
\text { District gross loan } \\
\text { portfolio per household }\end{array}$ & $\begin{array}{c}\text { (2) } \\
\text { MFI amt } \\
\text { outstanding, }\end{array}$ & $\begin{array}{c}\text { (3) } \\
\text { Bank amt } \\
\text { outstanding, }\end{array}$ & $\begin{array}{c}\text { (4) } \\
\text { Total loan amt } \\
\text { outstanding, }\end{array}$ & $\begin{array}{c}\text { (5) } \\
\text { MFI amt } \\
\text { outstanding, } \\
\text { log. } \\
\end{array}$ & $\begin{array}{c}\text { (6) } \\
\text { Bank amt } \\
\text { outstanding, } \\
\text { log. } \\
\end{array}$ & $\begin{array}{c}\text { (7) } \\
\text { Total loan amt } \\
\text { outstanding, } \\
\text { log. }\end{array}$ \\
\hline Any exposed lender $\times$ Post 2010 & $\begin{array}{c}-324.631 * * * * \\
(50.480)\end{array}$ & $\begin{array}{c}-1296.836^{* * * *} \\
(389.146)\end{array}$ & $\begin{array}{c}-815.937 \\
(1898.591)\end{array}$ & $\begin{array}{l}-3286.771 \\
(3004.950)\end{array}$ & $\begin{array}{c}-0.634 * * * \\
(0.159)\end{array}$ & $\begin{array}{c}0.123 \\
(0.244)\end{array}$ & $\begin{array}{c}-0.773 * * \\
(0.374)\end{array}$ \\
\hline Exposure Ratio $\times$ Post 2010 & $\begin{array}{c}-170.746 * * * \\
(23.670)\end{array}$ & $\begin{array}{c}-625.666 * * * \\
(185.231)\end{array}$ & $\begin{array}{c}465.037 \\
(900.364)\end{array}$ & $\begin{array}{l}-1067.915 \\
(1396.434)\end{array}$ & $\begin{array}{c}-0.331 * * * \\
(0.067)\end{array}$ & $\begin{array}{c}0.063 \\
(0.115)\end{array}$ & $\begin{array}{l}-0.355^{*} \\
(0.194)\end{array}$ \\
\hline Control mean & 423.496 & 2394.640 & 29531.260 & 69353.672 & -5.360 & -2.641 & 5.476 \\
\hline Control SD & 546.901 & 13200.690 & 104467.426 & 142601.618 & 4.836 & 7.641 & 8.028 \\
\hline Observations & 1048 & 33559 & 33559 & 33559 & 33559 & 33559 & 33559 \\
\hline
\end{tabular}

Note: Outcomes data in column 1 is from MFI balance sheets. Outcomes data in columns 2 to 7 is from the NSS 70th round "Debt and Investment" survey reflecting outstanding credit on June 30, 2012. Outcome variables are winsorized at the 99th percentile. Each cell provides coefficients from separate OLS regression specification. The first row reports coefficients from regressions using the binary indicator for high exposure to the AP crisis. The second row reports coefficients from separate regressions using the continuous exposure measure. The outcome of interest in columns 1 and 4 is total total formal, non-bank, non-collateralized credit (i.e., microfinance credit). Total bank credit is shown in column 2 and 5, and total credit in column 3 and 6 . The dependent variables in columns 1 to 3 are in levels, and outcomes are transformed using a $\log (X+.001)$ transformation for columns 4 to 6 . All columns include pre-crisis district-level controls. Balance sheet controls include levels and quintiles dummies for GLP measured in both 2008 and 2010. RBI controls include amount of credit outstanding and number of accounts for agricultural loans, direct loans, and indirect loans. NSS 66 controls include average monthly household expenditures, annual durables expenditures, weekly earnings from and days worked in self-employment, daily wage, and percent of weekly earnings from self-employment. Standard errors are clustered at the district level. Observations are weighted by NSS sampling weights.

TABLE 4. Labor Outcomes

\begin{tabular}{|c|c|c|c|c|c|c|c|}
\hline & $\begin{array}{c}(1) \\
\text { Casual } \\
\text { Daily } \\
\text { Wage }\end{array}$ & $\begin{array}{c}(2) \\
\text { HH Weekly } \\
\text { Total Days } \\
\text { Worked }\end{array}$ & $\begin{array}{c}\text { (3) } \\
\text { HH Weekly } \\
\text { Casual Days } \\
\text { Worked }\end{array}$ & $\begin{array}{c}\text { (4) } \\
\text { HH Weekly } \\
\text { Labor } \\
\text { Earnings }\end{array}$ & $\begin{array}{c}\text { (5) } \\
\text { Any HH } \\
\text { Member Invol } \\
\text { Unemployed }\end{array}$ & $\begin{array}{c}\text { (6) } \\
\mathrm{HH} \\
\text { is an } \\
\text { Employer }\end{array}$ & $\begin{array}{c}\text { (7) } \\
\text { HH } \\
\text { Operates } \\
\text { Business }\end{array}$ \\
\hline Any exposed lender $\times$ Post 2010 & $\begin{array}{c}-6.432 * * \\
(2.954)\end{array}$ & $\begin{array}{c}0.057 \\
(0.234)\end{array}$ & $\begin{array}{c}-0.446^{* *} \\
(0.196)\end{array}$ & $\begin{array}{c}-86.227 * * * \\
(30.333)\end{array}$ & $\begin{array}{c}0.012 \\
(0.011)\end{array}$ & $\begin{array}{l}-0.005 \\
(0.004)\end{array}$ & $\begin{array}{c}0.041 * * \\
(0.018)\end{array}$ \\
\hline Exposure Ratio $\times$ Post 2010 & $\begin{array}{c}-3.439 * * \\
(1.335)\end{array}$ & $\begin{array}{l}-0.063 \\
(0.111)\end{array}$ & $\begin{array}{l}-0.154 * \\
(0.089)\end{array}$ & $\begin{array}{c}-44.836^{* * *} \\
(14.181)\end{array}$ & $\begin{array}{c}0.002 \\
(0.005)\end{array}$ & $\begin{array}{l}-0.003 * \\
(0.002)\end{array}$ & $\begin{array}{l}0.013^{*} \\
(0.008)\end{array}$ \\
\hline Control mean & 153.361 & 10.275 & 3.455 & 836.465 & 0.098 & 0.035 & 0.584 \\
\hline Control SD & 87.097 & 6.738 & 5.134 & 1266.456 & 0.297 & 0.183 & 0.493 \\
\hline Observations & 40584 & 119668 & 119668 & 119668 & 119668 & 119668 & 119668 \\
\hline
\end{tabular}

Note: Outcomes data from NSS rounds 64, 66, 68. Each cell provides coefficients from separate differencesin-differences regressions. The first row reports coefficients from separate regressions using the binary indicator for high exposure to AP. The second row reports specifications that use the standardized continuous exposure measure. In all columns, controls include Round 66 average district consumption, average casual wage and linear distance to AP interacted with round, quintiles of household size, number of rural households and its squared term, GLP quintiles in 2008 and 2010 dummies along with round and survey month fixed effects. Wage and earnings are winsorized at the 99th percentile. Standard errors are clustered at the district level. Observations are weighted by NSS sampling weights. 
TABle 5. Casual Daily Wages by Sector

\begin{tabular}{|c|c|c|c|c|}
\hline & $\begin{array}{c}\text { (1) } \\
\text { Casual } \\
\text { Daily Wage: } \\
\text { Pooled } \\
\end{array}$ & $\begin{array}{c}(2) \\
\text { Casual } \\
\text { Daily Wage: } \\
\text { Men } \\
\end{array}$ & $\begin{array}{c}\text { (3) } \\
\text { Casual } \\
\text { Daily Wage: } \\
\text { Winsorized } \\
\end{array}$ & $\begin{array}{c}\text { (4) } \\
\text { Casual } \\
\text { Daily Wage: } \\
\text { Men, Win. }\end{array}$ \\
\hline (Any exposed lender x Post 2010) x Agriculture & $\begin{array}{l}-5.081 \\
(3.340)\end{array}$ & $\begin{array}{l}-4.231 \\
(3.732)\end{array}$ & $\begin{array}{c}-5.555^{*} \\
(3.173)\end{array}$ & $\begin{array}{l}-4.887 \\
(3.478)\end{array}$ \\
\hline (Any exposed lender x Post 2010) x Non-agriculture & $\begin{array}{c}-9.436 * * \\
(4.380)\end{array}$ & $\begin{array}{c}-9.194 * \\
(4.810)\end{array}$ & $\begin{array}{c}-7.949 * \\
(4.084)\end{array}$ & $\begin{array}{c}-7.819^{*} \\
(4.455)\end{array}$ \\
\hline p-value: $\mathrm{Ag}=$ non- $\mathrm{Ag}$ & 0.304 & 0.276 & 0.551 & 0.497 \\
\hline (Exposure Ratio x Post 2010) x Agriculture & $\begin{array}{c}-2.342 \\
(1.469)\end{array}$ & $\begin{array}{l}-1.737 \\
(1.665)\end{array}$ & $\begin{array}{c}-2.802 * * \\
(1.386)\end{array}$ & $\begin{array}{l}-2.365 \\
(1.550)\end{array}$ \\
\hline (Exposure Ratio x Post 2010) x Non-agriculture & $\begin{array}{c}-5.315 * * \\
(2.209)\end{array}$ & $\begin{array}{c}-5.072 * * \\
(2.487)\end{array}$ & $\begin{array}{c}-4.803 * * \\
(2.045)\end{array}$ & $\begin{array}{c}-4.680 * * \\
(2.279)\end{array}$ \\
\hline p-value: $\mathrm{Ag}=$ non- $\mathrm{Ag}$ & 0.155 & 0.150 & 0.311 & 0.290 \\
\hline Ag mean & 128.581 & 140.534 & 128.211 & 140.068 \\
\hline Non-ag mean & 184.242 & 194.709 & 178.099 & 187.703 \\
\hline Observations & 40584 & 29493 & 40584 & 29493 \\
\hline
\end{tabular}

Note: Outcomes data from NSS rounds 64, 66, 68. Each cell provides coefficients from separate differencesin-differences regressions. The first row reports coefficients from separate regressions using the binary indicator for high exposure to AP. The second row reports specifications that use the standardized continuous exposure measure. In all columns, controls include Round 66 average district consumption, average casual wage and linear distance to AP interacted with round, quintiles of household size, number of rural households and its squared term, GLP quintiles in 2008 and 2010 dummies along with round and survey month fixed effects. Outcomes in columns (3) and (4) are winsorized at the 99th percentile. Standard errors are clustered at the district level. Observations are weighted by NSS sampling weights.

TABle 6. Consumption Outcomes

\begin{tabular}{lcccc}
\hline & $\begin{array}{c}(1) \\
\text { HH Monthly } \\
\text { Consumption: } \\
\text { Total }\end{array}$ & $\begin{array}{c}\text { HH Monthly } \\
\text { Consumption: } \\
\text { Nondurables }\end{array}$ & $\begin{array}{c}\text { HH Monthly } \\
\text { Consumption: } \\
\text { Durables }\end{array}$ & $\begin{array}{c}\text { Below } \\
\text { Proverty } \\
\text { Line }\end{array}$ \\
\hline \multirow{2}{*}{ Any exposed lender $\times$ Post 2010 } & -138.218 & -89.202 & $-41.714 * *$ & 0.000 \\
& $(118.719)$ & $(106.911)$ & $(16.737)$ & $(0.021)$ \\
Exposure Ratio $\times$ Post 2010 & $-151.222^{* * *}$ & $-127.775 * * *$ & $-17.130^{* *}$ & 0.010 \\
& $(51.919)$ & $(46.950)$ & $(7.502)$ & $(0.010)$ \\
\hline Control mean & 5502.140 & 5183.746 & 284.541 & 0.254 \\
Control SD & 3433.515 & 2977.998 & 665.044 & 0.435 \\
Observations & 111692 & 119668 & 111692 & 111692 \\
\hline
\end{tabular}

Note: Outcomes data from NSS rounds 64, 66, 68. Each cell provides coefficients from separate differencesin-differences regressions. Notice that due to missing values the sample size for durable consumption is lower than for nondurable consumption. Total consumption and poverty are then considered missing when durable consumption is missing. The first row reports coefficients from separate regressions using the binary indicator for high exposure to AP. The second row reports specifications that use the standardized continuous exposure measure. In all columns, controls include Round 66 average district consumption, average casual wage and linear distance to AP interacted with round, quintiles of household size, number of rural households and its squared term, GLP quintiles in 2008 and 2010 dummies along with round and survey month fixed effects. Outcomes in columns (1) to (3) are winsorized at the 99th percentile. Standard errors are clustered at the district level. Observations are weighted by NSS sampling weights. 
TABLE 7. Exposure to the AP Crisis and Investment: NSS round 70 data

\begin{tabular}{|c|c|c|c|c|}
\hline & $\begin{array}{c}(1) \\
\text { Total } \\
\text { Investment }\end{array}$ & $\begin{array}{c}(2) \\
\text { Home } \\
\text { Improvements }\end{array}$ & $\begin{array}{c}\text { (3) } \\
\text { Ag. Business } \\
\text { Investment }\end{array}$ & $\begin{array}{c}\text { (4) } \\
\text { Non-Ag Business } \\
\text { Investment }\end{array}$ \\
\hline Any exposed lender $\times$ Post 2010 & $\begin{array}{c}-1121.526^{*} \\
(621.759)\end{array}$ & $\begin{array}{c}-814.906^{*} \\
(432.305)\end{array}$ & $\begin{array}{c}-30.892 \\
(144.726)\end{array}$ & $\begin{array}{l}-42.269 \\
(26.259)\end{array}$ \\
\hline Exposure Ratio $\times$ Post 2010 & $\begin{array}{c}-707.497 * * \\
(283.785)\end{array}$ & $\begin{array}{l}-362.950 * \\
(206.525)\end{array}$ & $\begin{array}{l}-49.709 \\
(67.861)\end{array}$ & $\begin{array}{c}-39.016 * * * \\
(12.163)\end{array}$ \\
\hline Control mean & 6002.832 & 3474.778 & 914.539 & 197.459 \\
\hline Control SD & 25315.784 & 17004.180 & 4394.461 & 1058.789 \\
\hline Observations & 33559 & 33559 & 33559 & 33559 \\
\hline
\end{tabular}

Note: Outcomes data from the NSS 70th round "Debt and Investment" survey reflecting investments made in home improvements and businesses between July 1, 2012 and December 31, 2012. Each cell provides coefficients from separate OLS regression specification. The first row reports coefficients from separate regressions using the binary indicator for high exposure to AP. The second row reports coefficients from separate regressions using the standardized continuous exposure measure. The dependent variables are levels and at the top 1 percentile. All columns include pre-crisis district-level controls. Balance sheet controls include levels and quintiles of GLP measured in both 2008 and 2010. RBI controls include amount of credit outstanding and number of accounts for agricultural loans, direct loans, and indirect loans. NSS 66 controls include average monthly household expenditures, annual durables expenditures, weekly earnings from and days worked in self-employment, daily wage, and percent of weekly earnings from self-employment. Other controls are Round 66 average district consumption, average casual wage and linear distance to AP interacted with round for survey months before July. Standard errors are clustered at the district level. Observations are weighted by NSS sampling weights. 
TABLE 8. Robustness: Distance to Andhra Pradesh

\begin{tabular}{|c|c|c|c|c|c|c|c|}
\hline & $\begin{array}{c}(1) \\
\text { HH Monthly } \\
\text { Consumption: } \\
\text { Total }\end{array}$ & $\begin{array}{c}(2) \\
\text { HH Monthly } \\
\text { Consumption: } \\
\text { Durables }\end{array}$ & $\begin{array}{c}\text { (3) } \\
\text { HH Weekly } \\
\text { Labor } \\
\text { Earnings }\end{array}$ & $\begin{array}{c}\text { (4) } \\
\text { HH Weekly } \\
\text { Casual Days } \\
\text { Worked }\end{array}$ & $\begin{array}{c}(5) \\
\text { Casual } \\
\text { Daily } \\
\text { Wage }\end{array}$ & $\begin{array}{c}\text { (6) } \\
\text { Ag } \\
\text { Daily } \\
\text { Wage }\end{array}$ & $\begin{array}{c}\text { (7) } \\
\text { Non-ag } \\
\text { Daily } \\
\text { Wage }\end{array}$ \\
\hline \multicolumn{8}{|l|}{ Panel A: Drop border districts } \\
\hline Any exposed lender $\times$ Post 2010 & $\begin{array}{c}-80.460 \\
(138.184)\end{array}$ & $\begin{array}{c}-62.285 * * * \\
(23.629)\end{array}$ & $\begin{array}{c}-65.691 * * \\
(33.075)\end{array}$ & $\begin{array}{c}-0.373 * \\
(0.192)\end{array}$ & $\begin{array}{l}-5.344 \\
(3.267)\end{array}$ & $\begin{array}{l}-4.075 \\
(3.346)\end{array}$ & $\begin{array}{l}-8.346 \\
(5.366)\end{array}$ \\
\hline Exposure Ratio $\times$ Post 2010 & $\begin{array}{c}-140.323 * * \\
(61.081)\end{array}$ & $\begin{array}{c}-21.820 * * \\
(10.498)\end{array}$ & $\begin{array}{c}-34.407 * * \\
(15.860)\end{array}$ & $\begin{array}{l}-0.127 \\
(0.091)\end{array}$ & $\begin{array}{l}-2.362 \\
(1.531)\end{array}$ & $\begin{array}{l}-1.921 \\
(1.490)\end{array}$ & $\begin{array}{l}-5.469 * \\
(2.839)\end{array}$ \\
\hline Observations & 105801 & 105801 & 113346 & 113346 & 37774 & 21546 & 16228 \\
\hline \multicolumn{8}{|c|}{ Panel B: Control for travel time to Hyderabad $\times$ round } \\
\hline Any exposed lender $\times$ Post 2010 & $\begin{array}{l}-223.379 * \\
(132.922)\end{array}$ & $\begin{array}{c}-66.768 * * * \\
(23.268)\end{array}$ & $\begin{array}{c}-81.361 * * \\
(32.859)\end{array}$ & $\begin{array}{c}-0.465^{* *} \\
(0.188)\end{array}$ & $\begin{array}{l}-4.561 \\
(3.050)\end{array}$ & $\begin{array}{l}-4.146 \\
(3.238)\end{array}$ & $\begin{array}{l}-6.689 \\
(5.328)\end{array}$ \\
\hline Exposure Ratio $\times$ Post 2010 & $\begin{array}{c}-187.652 * * * \\
(56.557)\end{array}$ & $\begin{array}{c}-24.763 * * \\
(10.292)\end{array}$ & $\begin{array}{c}-40.195 * * * \\
(15.429)\end{array}$ & $\begin{array}{l}-0.162^{*} \\
(0.086)\end{array}$ & $\begin{array}{l}-2.643^{*} \\
(1.374)\end{array}$ & $\begin{array}{l}-2.594 * \\
(1.389)\end{array}$ & $\begin{array}{l}-5.150 * \\
(2.688)\end{array}$ \\
\hline Observations & 111692 & 111692 & 119668 & 119668 & 40584 & 23444 & 17140 \\
\hline
\end{tabular}

Note: Outcomes data from NSS rounds 64, 66, 68. In each panel, each cell provides coefficients from separate differences-in-differences regressions. The first row reports coefficients from separate regressions using the binary indicator for high exposure to AP. The second row reports specifications that use the standardized continuous exposure measure. In all columns, controls include Round 66 average district consumption, average casual wage and linear distance to AP interacted with round, quintiles of household size, number of rural households and its squared term, GLP quintiles in 2008 and 2010 dummies along with round and survey month fixed effects. In the first panel, the sample is restricted to districts that share no border with Andhra Pradesh. In the second panel, we use instead the road travel time between each district and Hyderabad as calculated by Allen and Atkin (2016). Standard errors are clustered at the district level. Observations are weighted by NSS sampling weights. 
TABle 9. Urban Sample

\begin{tabular}{|c|c|c|c|c|c|}
\hline & $\begin{array}{c}\text { (1) } \\
\text { HH Monthly } \\
\text { Consumption: } \\
\text { Total }\end{array}$ & $\begin{array}{c}(2) \\
\text { HH Weekly } \\
\text { Labor } \\
\text { Earnings }\end{array}$ & $\begin{array}{c}(3) \\
\text { Casual } \\
\text { Daily Wage, } \\
\text { All } \\
\end{array}$ & $\begin{array}{c}(4) \\
\text { Casual } \\
\text { Daily Wage, } \\
\text { Non-ag. } \\
\end{array}$ & $\begin{array}{c}\text { Casual } \\
\text { Daily Wage, } \\
\text { Ag. } \\
\end{array}$ \\
\hline \multicolumn{6}{|c|}{ Panel A: Close to the state capital city } \\
\hline Any exposed lender $\times$ Post 2010 & $\begin{array}{c}216.792 \\
(493.005)\end{array}$ & $\begin{array}{c}236.754 \\
(232.892)\end{array}$ & $\begin{array}{c}17.214 * * \\
(7.877)\end{array}$ & $\begin{array}{c}20.018 * * * \\
(7.300)\end{array}$ & $\begin{array}{c}7.603 \\
(27.189)\end{array}$ \\
\hline Exposure Ratio $\times$ Post 2010 & $\begin{array}{c}236.021 \\
(280.541)\end{array}$ & $\begin{array}{c}146.021 \\
(121.632)\end{array}$ & $\begin{array}{c}1.855 \\
(5.604)\end{array}$ & $\begin{array}{c}4.861 \\
(5.531)\end{array}$ & $\begin{array}{l}-12.837 \\
(13.346)\end{array}$ \\
\hline Control Mean & 10123.126 & 2339.072 & 175.832 & 180.907 & 126.925 \\
\hline Control Std. Dev. & 7797.135 & 4382.527 & 115.457 & 118.100 & 69.447 \\
\hline Observations & 23017 & 25046 & 3409 & 3064 & 345 \\
\hline \multicolumn{6}{|c|}{ Panel B: Far from the state capital city } \\
\hline Any exposed lender $\times$ Post 2010 & $\begin{array}{c}-567.098 * \\
(296.630)\end{array}$ & $\begin{array}{c}-22.677 \\
(113.159)\end{array}$ & $\begin{array}{l}-7.518 \\
(9.579)\end{array}$ & $\begin{array}{l}-6.861 \\
(9.907)\end{array}$ & $\begin{array}{l}-23.101^{*} \\
(13.384)\end{array}$ \\
\hline Exposure Ratio $\times$ Post 2010 & $\begin{array}{c}-2.864 \\
(141.737)\end{array}$ & $\begin{array}{l}-12.651 \\
(44.275)\end{array}$ & $\begin{array}{l}-3.529 \\
(3.178)\end{array}$ & $\begin{array}{l}-2.987 \\
(3.601)\end{array}$ & $\begin{array}{l}-1.953 \\
(3.685)\end{array}$ \\
\hline Control Mean & 8258.857 & 1702.766 & 186.823 & 194.310 & 138.571 \\
\hline Control Std. Dev. & 7154.528 & 3174.552 & 99.577 & 101.818 & 65.875 \\
\hline Observations & 46967 & 50592 & 8699 & 7247 & 1452 \\
\hline
\end{tabular}

Note: Outcomes data from NSS rounds $64,66,68$. The first rows provides coefficients using the binary indicator for high exposure to AP. The second rows report specifications that use the standardized continuous exposure measure. In Panel A, the sample is restricted to districts for which the centroid is within 100 $\mathrm{km}$ of the state capital. In Panel B, the sample is restricted to districts that are at a distance larger than 100 $\mathrm{km}$. In all columns, controls include Round 66 average district consumption, average casual wage and linear distance to AP interacted with round, quintiles of household size, number of urban households and its squared term, GLP quintiles in 2008 and 2010 dummies along with round and survey month fixed effects. Standard errors are clustered at the district level. Observations are weighted by NSS sampling weights.

\section{TABLE 10. General Equilibrium Effect Studies}

\begin{tabular}{|c|c|c|c|c|}
\hline Channel & Study & Country & Wage Impact & "First Stage" Scaling \\
\hline \multirow[b]{2}{*}{ Credit Supply } & \multirow{2}{*}{$\begin{array}{l}\text { Burgess and Pande (2003) } \\
\text { Kaboski and Townsend (2012) }\end{array}$} & \multirow{2}{*}{$\begin{array}{l}\text { India } \\
\text { Thailand }\end{array}$} & $7 \%$ (ag wage) & 1 bank branch per 100,000 people \\
\hline & & & $\begin{array}{l}7 \% \text { (avg wage) } \\
28 \% \text { (construction wage) }\end{array}$ & $43 \%$ increase in short term credit \\
\hline \multirow{2}{*}{ Labor Demand } & Imbert and Papp (2014) & India & $4.7 \%$ (ag wage) & $1.3 \%$ demand shift from NREGA \\
\hline & Muralidharan et al (2017) & India & $6.1 \%$ (total wage) & $6 \%$ demand shift from NREGA \\
\hline Labor Supply & Akram et al (2017) & Bangladesh & $2.8 \%$ (ag wage) & $10 \%$ increase in emigration \\
\hline Cash Transfer & Egger et al (2019) & Kenya & $16-27 \%$ & cash worth $17 \%$ of GDP \\
\hline
\end{tabular}




\section{Online Appendix}

\section{Appendix A. Two-Sector Model of Credit and Aggregate Demand}

Here, we present a simple two-sector, two-period model with consumption credit to explore the aggregate demand channel. In this simple economy, firms have no wealth constraints, there is no capital, so no adjustment costs, and no storage technology for firm output. Thus firms maximize profits, statically each period in response to consumer demand. Households are endowned with inelastic labor supply each period and growing nonlabor income across periords. Our goal is to understand how wages in each sector change following a shock to credit supply in the first period of the model, limiting the ability of households to borrow from their future wealth to finance consumption.

A.1. Setting up the Problem. ${ }^{41}$ The economy lasts for two periods $t \in\{1,2\}$. Firms come in two sectors: $S \in\{T, N T\}$, and workers in two types: $k \in\{\ell, h\}$, denoting low and high skill. Because we are especially interested in how period 1 credit supply affects the labor market equilibrium, when subscripts $t$ are missing, we assume $t=1$.

In what follows we assume that labor markets are partially segmented, in the following sense. High-skilled workers are no more productive than low-skilled workers in the $T$ sector and are perfect substitutes, while the high- and low-skilled workers are only imperfect substitutes in the NT sector, and $h$ types can be more productive. This means that in equilibrium all high-skilled workers will sort into the $N T$ sector and will receive a higher wage. Low-skilled workers will be split between the two sectors, and the average NT wage will be higher than the average $T$ wage.

The only input of production is labor, and firms face no financial constraints (e.g., workers can be paid after revenues are received). The NT sector uses both types of labor, while the $T$ sector uses only $\ell$ labor. Each period $t$, production functions are:

$$
\begin{aligned}
Y_{t}^{T} & =A^{T}\left(L_{t}^{T, \ell}\right)^{\gamma} \\
Y_{t}^{N T} & =A^{N T}\left(\left(L_{t}^{N T, \ell}\right)^{\rho}+\theta\left(L_{t}^{N T, h}\right)^{\rho}\right)^{\frac{\gamma}{\rho}}
\end{aligned}
$$

where $\rho<\gamma<1$.

Each period, firms sell their products for price $P_{t}^{S}$. We assume there is no storage technology, so all production needs to be sold each period. We normalize $P_{1}^{T}=1$ and denote $P_{1}^{N T}=P$. Workers of type $h$ are paid $w_{t}^{h}$, and workers of type $\ell$ are paid $w_{t}^{l}$. Firms make period 1 hiring decisions by maximizing profits. Dropping the time subscripts to denote

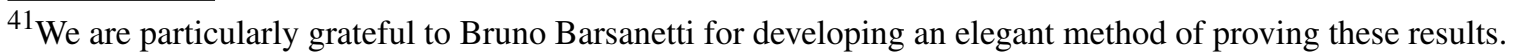


$t=1$, period 1 profits are given by:

$$
\Pi^{S}=P^{S} Y^{S}-w^{\ell} L^{S, \ell}-w^{h} L^{S, h}
$$

Firms have no access to credit, but also have no need for credit in this simplified economy.

The workers are also the consumers of the firms' output. Consumers are risk neutral, but impatient, and discount period 2 consumption by $\beta<1$. Each period, workers of each type prefer to consumer both the $T$ and the $N T$ goods $\left(C_{t}^{T, k}, C_{t}^{N T, k}\right)$ according to the aggregator:

$$
u\left(C_{t}^{T, k}, C_{t}^{N T, k}\right)=\left(C_{t}^{T, k}\right)^{\alpha}\left(C_{t}^{N T, k}\right)^{1-\alpha}
$$

where $0<\alpha<1$

Moreover, each household is endowed with deterministic non-labor income in each period, $y_{t}$. We assume this income is growing over time: $y_{2}>y_{1}$. Households can take microloans for consumption. If they borrow, they get a fixed disbursement $B$ in period 1 , and repay $R B$ in period 2 with commitment, where where $R B<<y_{2}$.

If they borrow, workers face the following budget constraints in each period:

$$
\begin{array}{r}
C_{1}^{T, k}+P C_{1}^{N T, k}=y_{1}+w_{1}^{k}+B \\
P_{2}^{T} C_{2}^{T, k}+P_{2}^{N T} C_{2}^{N T, k}=y_{2}+w_{2}^{k}-R B
\end{array}
$$

Each period, individuals maximize the utility from consumption subject to these budget constraints. Their only choice is whether to take a period 1 consumption loan. We assume $\beta R<1$ and that price expectations are such that consumers choose to borrow in period 1 .

Focusing on period $t=1$, consumers of worker type $k$ maximize within-period utility subject to a budget constraint. Notably:

$$
\begin{gathered}
\max _{C^{T, k}, C^{N T, k}}\left(C^{T, k}\right)^{\alpha}\left(C^{N T, k}\right)^{1-\alpha} \\
\text { s.t. } C^{T, k}+P C^{N T, k} \leq w^{k}+y_{1}+B
\end{gathered}
$$

For simplicity, we normalize $y_{1}=0$. Given the Cobb-Douglas structure, consumers will spend constant budget shares on each good:

$$
\begin{aligned}
C^{T, k} & =\alpha\left(w^{k}+B\right) \\
C^{N T, k} & =\frac{1-\alpha}{P}\left(w^{k}+B\right)
\end{aligned}
$$

A.2. Equilibrium Conditions. Both labor markets and the non-tradable product market clear: 


$$
\begin{aligned}
L^{T, \ell}+L^{N T, \ell} & =N^{\ell} \\
L^{N T, h} & =N^{h} \\
N^{\ell} C^{N T, \ell}+N^{h} C^{N T, h} & =A^{N T}\left(\left(L^{N T, \ell}\right)^{\rho}+\theta\left(L^{N T, h}\right)^{\rho}\right)^{\frac{\gamma}{\rho}}
\end{aligned}
$$

\section{A.3. Comparative Statics by Credit Supply.}

Proposition: When high- and low-skilled labor are imperfect substitutes in the non-tradable sector, in period $1, \frac{d w^{h}}{d B} \frac{B}{w^{h}}>\frac{d w^{\ell}}{d B} \frac{B}{w^{\ell}}>0$.

Proof: We begin by solving the firm's problem, which yields the following FOC:

$$
\gamma A^{T}\left(L^{T, \ell}\right)^{\gamma-1}=w^{\ell}
$$

Rearranging,

$$
L^{T, \ell}=\left(\frac{\gamma A^{T}}{w^{\ell}}\right)^{\frac{1}{1-\gamma}}
$$

The maximization problem of $N T$ firms yields the following FOCs:

$$
\begin{gathered}
\gamma P A^{N T}\left(\left(L^{N T, \ell}\right)^{\rho}+\theta\left(L^{N T, h}\right)^{\rho}\right)^{\frac{\gamma}{\rho}-1}\left(L^{N T, \ell}\right)^{\rho-1}=w^{\ell} \\
\gamma \theta P A^{N T}\left(\left(L^{N T, \ell}\right)^{\rho}+\theta\left(L^{N T, h}\right)^{\rho}\right)^{\frac{\gamma}{\rho}-1}\left(L^{N T, h}\right)^{\rho-1}=w^{h}
\end{gathered}
$$

Simplifying,

$$
\begin{aligned}
L^{N T, h} & =L^{N T, \ell}\left(\frac{w^{\ell} \theta}{w^{h}}\right)^{\frac{1}{1-\rho}} \\
L^{N T, \ell} & =\left[\frac{\gamma P A^{N T}}{w^{\ell}}\left(1+\theta\left(\frac{w^{\ell} \theta}{w^{h}}\right)^{\frac{\rho}{1-\rho}}\right)^{\frac{\gamma-\rho}{\rho}}\right]^{\frac{1}{1-\gamma}}
\end{aligned}
$$

Plugging the demands into the equilibrium conditions yields:

$$
\begin{aligned}
\left(\frac{\gamma A^{T}}{w^{\ell}}\right)^{\frac{1}{1-\gamma}}+\left[\frac{\gamma P A^{N T}}{w^{\ell}}\left(1+\theta\left(\frac{w^{\ell} \theta}{w^{h}}\right)^{\frac{\rho}{1-\rho}}\right)^{\frac{\gamma-\rho}{\rho}}\right]^{\frac{1}{1-\gamma}} & =N^{\ell} \\
{\left[\frac{\gamma P A^{N T}}{w^{\ell}}\left(1+\theta\left(\frac{w^{\ell} \theta}{w^{h}}\right)^{\frac{\rho}{1-\rho}}\right)^{\frac{\gamma-\rho}{\rho}}\right]^{\frac{1}{1-\gamma}}\left(\frac{w^{\ell} \theta}{w^{h}}\right)^{\frac{1}{1-\rho}} } & =N^{h} \\
N_{1} \frac{1-\alpha}{P}\left(w^{\ell}+y\right)+N_{2} \frac{1-\alpha}{P}\left(w^{h}+y\right) & =A^{N T}\left(\left(L^{N T, \ell}\right)^{\rho}+\theta\left(L^{N T, h}\right)^{\rho}\right)^{\frac{\gamma}{\rho}}
\end{aligned}
$$


To simplify, we can solve for $P$ using the third equation

$$
\frac{1-\alpha}{A^{N T}\left(\left(L^{N T, \ell}\right)^{\rho}+\theta\left(L^{N T, h}\right)^{\rho}\right)^{\frac{\gamma}{\rho}}}\left(N^{\ell} w^{\ell}+N^{h} w^{h}+B\left(N^{\ell}+N^{h}\right)\right)=P
$$

and we can substitute $L^{N T, \ell}=L^{N T, h}\left(\frac{w^{\ell} \theta}{w^{h}}\right)^{\frac{-1}{1-\rho}}=N^{h}\left(\frac{w^{\ell} \theta}{w^{h}}\right)^{\frac{-1}{1-\rho}}$. So,

$$
P=(1-\alpha) \frac{N^{\ell} w^{\ell}+N^{h} w^{h}+B\left(N^{\ell}+N^{h}\right)}{A^{N T} N_{h}^{\gamma}\left(\left(\frac{w^{\ell} \theta}{w^{h}}\right)^{\frac{-\rho}{1-\rho}}+\theta\right)^{\frac{\gamma}{\rho}}}
$$

Similarly, from the equilibrium condition of the type 2 workers,

$$
P=\left(1+\theta\left(\frac{w^{\ell} \theta}{w^{h}}\right)^{\frac{\rho}{1-\rho}}\right)^{\frac{\rho-\gamma}{\rho}} \frac{w^{\ell}}{\gamma A^{N T}}\left(\frac{w^{\ell} \theta}{w^{h}}\right)^{\frac{-(1-\gamma)}{1-\rho}} N_{h}^{1-\gamma}
$$

Combining the $P$ equations yields

$$
N^{\ell} w^{\ell}+N^{h} w^{h}+B\left(N^{\ell}+N^{h}\right)=\frac{w^{\ell}}{\gamma(1-\alpha)}\left(\left(\frac{w^{h}}{w^{\ell} \theta}\right)^{\frac{1}{1-\rho}}+\frac{w^{h}}{w^{\ell}}\right) N^{h}
$$

Rearranging and using the first condition A.8, we can collapse the equilibrium conditions:

$$
\begin{array}{r}
\left(\frac{\gamma A^{T}}{w^{\ell}}\right)^{\frac{1}{1-\gamma}}+N^{h}\left(\frac{w^{h}}{w^{\ell} \theta}\right)^{\frac{1}{1-\rho}}-N^{\ell}=0 \\
\frac{w^{\ell}}{\gamma(1-\alpha)}\left(\left(\frac{w^{h}}{w^{\ell} \theta}\right)^{\frac{1}{1-\rho}}+\frac{w^{h}}{w^{\ell}}\right) N^{h}-N^{\ell} w^{\ell}+N^{h} w^{h}+B\left(N^{\ell}+N^{h}\right)=0
\end{array}
$$

To solve the system and derive comparative statics, we introduce a change of variables.

- $\omega=\frac{w^{h}}{w^{\ell}}$ be the relative wage to high-skill (non-tradable) workers;

- $\nu=\frac{1}{w^{\ell}}$ be the inverse of low-skill (tradable) wages.

If we divide the second equation by $w^{\ell}$ and replace the variables, our system becomes:

$$
\begin{array}{r}
\left(\gamma A^{T} \nu\right)^{\frac{1}{1-\gamma}}+N^{h}\left(\frac{\omega}{\theta}\right)^{\frac{1}{1-\rho}}-N^{\ell}=0 \\
\frac{N^{h}}{\gamma(1-\alpha)}\left(\left(\frac{\omega}{\theta}\right)^{\frac{1}{1-\rho}}+\omega\right)-N^{\ell}-N^{h} \omega-y\left(N_{1}+N^{h}\right) \nu=0
\end{array}
$$

We can isolate $\nu$ in the second equation to obtain:

$$
\nu=\frac{\frac{N^{h}}{\gamma(1-\alpha)}\left[\left(\frac{\omega}{\theta}\right)^{\frac{1}{1-\rho}}+\omega\right]-N^{\ell}-N^{h} \omega}{B\left(N^{\ell}+N^{h}\right)}
$$




$$
\nu=\frac{n_{h}\left(\frac{\omega}{\theta}\right)^{\frac{1}{1-\rho}}+n_{h} \omega[1-\gamma(1-\alpha)]-n_{\ell}}{\gamma(1-\alpha) B}
$$

where $n_{i}=\frac{N_{i}}{N_{1}+N^{h}}$. If we replace $\nu$ in the first system equation, after rearranging we have:

$$
\frac{(1-\alpha) B}{A^{T}}=\frac{n_{h}\left(\frac{\omega}{\theta}\right)^{\frac{1}{1-\rho}}+n_{h} \omega[1-\gamma(1-\alpha)]-n_{1}}{\left[N^{\ell}-N^{h}\left(\frac{\omega}{\theta}\right)^{\frac{1}{1-\rho}}\right]^{1-\gamma}}
$$

The LHS is a linear and increasing function of $B$, and the RHS is strictly increasing in the relative wages $\omega$. Hence, $\frac{w^{h}}{w^{\ell}}$ is increasing in B; that is, the elasticity of the highskilled wage (with respect to B) will be higher than the elasticity of the low-skilled wage. If $w^{h}>w^{\ell}$ in equilibrium, then the absolute change in $w^{h}$ will be larger than for $w^{\ell}$.

Finally, we can show that both wages go up with $B$. First, notice that:

$$
\left[n_{h}\left(\frac{\omega}{\theta}\right)^{\frac{[1}{1-\rho}}+n_{h} \omega[1-\gamma(1-\alpha)]-n_{\ell}=\frac{(1-\alpha) B}{A^{T}}\left[N^{\ell}-N^{h}\left(\frac{\omega}{\theta}\right)^{\frac{1}{1-\rho}}\right]^{1-\gamma}\right.
$$

And so we can substitute in the expression for $\nu$ to get:

$$
\nu=\frac{1}{A^{T}}\left[N^{\ell}-N^{h}\left(\frac{\omega}{\theta}\right)^{\frac{1}{1-\rho}}\right]^{1-\gamma}
$$

which depends on $B$ only through $\omega$. Hence, $\nu$ is decreasing in $B$, so both $w^{\ell}$ and $w^{h}$ are increasing in $B$.

A.4. Special Case: Fully Segmented Markets. Here, we solve for the limiting case of fully segmented labor markets. $\ell$ types have 0 productivity in the $N T$ sector. This has the advantage of producing simple, closed form solutions for equilibrium wage levels.

A.4.1. Setting up the Problem. Here we assume that the NT sector uses only $h$ labor, while the $T$ sector uses only $\ell$ labor. Production functions are:

$$
\begin{aligned}
Y^{T} & =A^{T}\left(L^{T, \ell}\right)^{\gamma} \\
Y^{N T} & =A^{N T}\left(L^{N T, h}\right)^{\gamma}
\end{aligned}
$$

where $\gamma<1$.

A.4.2. Equilibrium Conditions. Again, both labor markets and the non-tradable product market clear:

$$
L^{T, \ell}=N^{\ell}
$$


(A.14)

$$
L^{N T, h}=N^{h}
$$

$$
N^{\ell} C^{N T, \ell}+N^{h} C^{N T, h}=A^{N T}\left(L^{N T, h}\right)^{\gamma}
$$

A.4.3. Solving the Problem. The FOCs of $T$ and $N T$ firms yield:

$$
\begin{aligned}
L^{T, \ell} & =\left(\frac{\gamma A^{T}}{w^{\ell}}\right)^{\frac{1}{1-\gamma}}=N^{\ell} \\
L^{N T, h} & =\left(\frac{\gamma P A^{N T}}{w^{h}}\right)^{\frac{1}{1-\gamma}}=N^{h}
\end{aligned}
$$

From here, we can solve for $w^{\ell}$

$$
w^{\ell}=\frac{\gamma A^{T}}{\left(N^{\ell}\right)^{1-\gamma}}
$$

Note that $w^{\ell}$ is only a function here of model preliminaries, and is not a function of $B$. Thus $\frac{d w^{\ell}}{d B}=0$.

Plugging the consumption demands, $w^{\ell}$, and $P$ into the equilibrium condition yields:

$$
\begin{aligned}
\left(N^{\ell}+N^{h}\right) B+N^{\ell}\left(\frac{\gamma A^{T}}{\left(N^{\ell}\right)^{1-\gamma}}\right)+N^{h}\left(w^{h}\right) & =\frac{\frac{\left(N^{h}\right)^{1-\gamma}}{A^{N T} \gamma} w^{h}}{1-\alpha} A^{N T}\left(N^{h}\right)^{\gamma} \\
w^{h} & =\frac{\gamma(1-\alpha)}{1-\gamma(1-\alpha)}\left(\frac{\left(N^{\ell}+N^{h}\right)}{N^{h}} B+\frac{N^{\ell}}{N^{h}}\left(\frac{\gamma A^{T}}{\left(N^{\ell}\right)^{1-\gamma}}\right)\right)
\end{aligned}
$$

Finally, note that $\frac{d w^{h}}{d B}=\frac{\gamma(1-\alpha)}{1-\gamma(1-\alpha)} \frac{\left(N^{\ell}+N^{h}\right)}{N^{h}}>0$. Thus $\frac{d w^{h}}{d B}>0$ and $\frac{d w^{\ell}}{d B}=0$ when the labor market is fully segmented. 


\section{ApPEndix B. AdDitional RoBUstness CHECKS}

Placebo regression. To provide support for the identifying assumption that exposed and unexposed districts had similar counterfactual outcomes in the absence of the balance sheet effects of the crisis, Appendix Table C.6 conducts a placebo test, dropping the round 68 data and assigning the round 66 observations the status of Post. Reassuringly, for none of the main outcomes is the placebo treatment significant at standard levels. Moreover, the point estimates are all much smaller in magnitude than those of the main regressions.

Randomization Inference and Placebo Shocks. As a further check of the possibility that our results are spurious, Appendix Table C.9 reports alternate p-values using randomization inference. The resulting p-values are generally very similar those in our main tables. Appendix Table C.9 reports the results of a robustness test that permutes the location of the location of the initial microfinance regulation shock. We show that the true shock location - Andhra Pradesh - delivers impacts in the tail of the empirical distribution of potential shock locations. Appendix Section C.4 provides further details for both exercises.

Economic Conditions, Political Affinity with AP, and Rainfall. We check that our results are not driven by time-varying differences in other economic characteristics. In Appendix Table C.12 Panel A, we allow districts with different levels of baseline self-help group (SHG) presence to evolve differently. This test reflects the concern that areas with more SHG presence might have been perceived to have a greater risk of a crisis similar to that of AP. In Panels B and C, we allow districts with different levels of baseline poverty or self-employment, respectively, to evolve differently. In all three cases, our results remain quite similar to the baseline specification.

We also investigate whether the shock to AP may have spread to other places with similar political ideologies, for instance because of greater concern about a default episode occurring in politically-similar states. In Appendix Table C.10 Panel A, we allow all states with a certain party in power to be on a differential trend. In Panel B we adopt a more parsimonious specification, with an indicator for whether a given state was ruled by the same political party as AP in 2010. In both cases, our results remain robust.

Finally, we check that the differences between high and low exposure districts after 2010 are not coming from (random but unlucky) differences in rainfall. We construct an index for abnormal rainfall using the methodology of Jayachandran (2006). In Appendix Table C.11, we run our main specification, including time varying rainfall realizations, and find no major differences with our main results. 
Migration. One possible threat to our identification strategy is that households in areas more exposed to the crisis might migrate to other, less- or un-affected districts, pushing wages down in the destinations. This would amount to a negative spillover to the control group, potentially biasing our estimated effects toward zero. In Panel A of Appendix Table C.13, we examine household size as an outcome using our standard regression specifications. If exposed households are sending some members to work in other districts, we should see a negative treatment effect on household size. However, we find a precisely estimated zero effect. As an additional check, in Panels B and $\mathrm{C}$ we add a control for the baseline (i.e., 2008) district-level rate of inter-district migration and an indicator for being in a high- vs. low-baseline migration district, respectively. The results remain very similar.

Robustness to tails. We perform two checks to ensure that our effects are not driven by the treatment of the tails of our data. First, in Appendix Table C.14, we perform quantile regressions for the 25 th, 50 th and 75 th percentiles of the distribution. Significant negative effects on key outcomes are seen at the median and 75th percentiles, suggesting that our effects are not driven solely by a few observations. ${ }^{42}$

Second, as noted above, our main results use data winsorized at the 99th percentile since the data exhibit a few extreme values that appear to be data entry errors. In Appendix Table C.16 we report effects on the same key outcomes using un-winsorized data. Reassuringly, the results are very similar.

Multiple testing. Finally, becauase we measure the impacts of credit on multiple key outcomes, we present q-values to control the false discovery rate in Appendix Table C.17 (Anderson, 2008). Reassuringly, all of our key estimates remain significant at conventional levels. $^{43}$

\footnotetext{
${ }^{42}$ For computational reasons, the quantile regressions are estimated on un-weighted data, meaning that we do not re-weight to account for the sampling design of the NSS, which over-samples less populous areas. For comparison, Appendix Table C.15 presents un-weighted OLS regressions. The resulting estimates are somewhat larger in magnitude than the weighted estimates, suggesting that the effects are larger in less populous places, likely due to thinner markets and/or less market integration.

${ }^{43}$ Anderson notes that sharpened q-values can be smaller than unadjusted p-values in some cases when many hypotheses are rejected, because if there are many true rejections, one can tolerate several false rejections too while maintaining the false discovery rate. This occurs in several cases in Appendix Table C.17.
} 


\section{ApPendix C. Supplementary Figures AND TABles}

\section{C.1. Baseline Balance.}

TABLE C.1. Baseline Balance

\begin{tabular}{lccccccc}
\hline & $\begin{array}{c}(1) \\
\text { Distance } \\
\text { to AP }\end{array}$ & $\begin{array}{c}(2) \\
\text { District } \\
\text { Borders AP }\end{array}$ & $\begin{array}{c}(3) \\
\text { Casual Daily } \\
\text { Wage: } \\
\text { Agriculture }\end{array}$ & $\begin{array}{c}(4) \\
\text { Casual Daily } \\
\text { Wage: } \\
\text { Non-agriculture }\end{array}$ & $\begin{array}{c}\text { HH Weekly } \\
\text { Labor } \\
\text { Earnings }\end{array}$ & $\begin{array}{c}\text { HH Monthly } \\
\text { Consumption: } \\
\text { Non-durables }\end{array}$ & $\begin{array}{c}\text { HH Monthly } \\
\text { Consumption: } \\
\text { Durables }\end{array}$ \\
\hline Any exposed lender $\times$ Post 2010 & -20.366 & $0.079 * *$ & 1.734 & -0.678 & 28.397 & 57.278 & $44.939 * *$ \\
& $(18.096)$ & $(0.037)$ & $(1.395)$ & $(1.358)$ & $(24.081)$ & $(84.988)$ & $(19.232)$ \\
Exposure Ratio $\times$ Post 2010 & -9.835 & $0.036 * *$ & 0.344 & 0.253 & 11.761 & 64.226 & 7.792 \\
Observations & $(9.116)$ & $(0.015)$ & $(0.621)$ & $(0.636)$ & $(13.207)$ & $(48.154)$ & $(9.566)$ \\
\hline
\end{tabular}

Note: Outcomes from NSS round 66. Each row provides coefficients from separate regressions. The first row reports coefficients from separate regressions using the binary indicator for high exposure to AP. The second row reports specifications that use the standardized continuous exposure measure. The dependent variable is the average across households in each district in round 66. In all columns, controls include Round 66 average district consumption, average casual wage and linear distance to AP interacted with round, number of rural households and its squared term and GLP quintiles in 2008 and 2010 dummies. In columns (3) to (7), the average of the dependent variable in round 64 is also used as a control. Robust standard errors in parenthesis. Observations are weighted by NSS sampling weights. 


\section{C.2. Robustness: Lending Impacts.}

TABLE C.2. Exposure to the AP Crisis and commercial bank lending: RBI data

\begin{tabular}{|c|c|c|c|c|c|c|}
\hline & $\begin{array}{c}(1) \\
\text { No. } \\
\text { accounts } \\
\text { (agriculture) } \\
(\operatorname{logs})\end{array}$ & $\begin{array}{c}\text { (2) } \\
\text { Amt } \\
\text { outstanding } \\
\text { (agriculture) } \\
\text { (logs) }\end{array}$ & $\begin{array}{c}(3) \\
\text { No. } \\
\text { accounts } \\
(\text { direct }) \\
(\operatorname{logs})\end{array}$ & $\begin{array}{c}\text { (4) } \\
\text { Amt } \\
\text { outstanding } \\
\text { (direct) } \\
(\operatorname{logs})\end{array}$ & $\begin{array}{c}(5) \\
\text { No. } \\
\text { accounts } \\
\text { (indirect) } \\
(\log )\end{array}$ & $\begin{array}{c}\text { (6) } \\
\text { Amt } \\
\text { outstanding } \\
\text { (indirect) } \\
(\operatorname{logs})\end{array}$ \\
\hline Any exposed lender $\times$ Post 2010 & $\begin{array}{c}0.021 \\
(0.037)\end{array}$ & $\begin{array}{c}0.070 \\
(0.047)\end{array}$ & $\begin{array}{c}0.042 \\
(0.038)\end{array}$ & $\begin{array}{c}0.087 * * \\
(0.041)\end{array}$ & $\begin{array}{c}-0.367 * * \\
(0.147)\end{array}$ & $\begin{array}{l}-0.227^{*} \\
(0.124)\end{array}$ \\
\hline Exposure Ratio $\times$ Post 2010 & $\begin{array}{c}0.010 \\
(0.017)\end{array}$ & $\begin{array}{c}0.034 \\
(0.026)\end{array}$ & $\begin{array}{c}0.021 \\
(0.017)\end{array}$ & $\begin{array}{l}0.041^{*} \\
(0.021)\end{array}$ & $\begin{array}{c}-0.212 * * * \\
(0.065)\end{array}$ & $\begin{array}{l}-0.094 \\
(0.061)\end{array}$ \\
\hline Control mean & 11.564 & 15.944 & 11.509 & 15.795 & 8.113 & 13.659 \\
\hline Control SD & 0.732 & 0.773 & 0.711 & 0.772 & 1.402 & 1.143 \\
\hline Observations & 1031 & 1031 & 1031 & 1031 & 1031 & 1031 \\
\hline
\end{tabular}

Note: Outcomes data from RBI "District-Wise Classification of Outstanding Credit of Scheduled Commercial Banks". Each cell provides coefficients from separate differences-in-differences regressions. The first row reports coefficients from separate regressions using the binary indicator for high exposure to AP. The second row reports specifications that use the standardized continuous exposure measure. In all columns, controls include Round 66 average district consumption, average casual wage and linear distance to AP interacted with round, quintiles of total households times round, GLP quintiles in 2008 and 2010 dummies along with round fixed effects. Standard errors are clustered at the district level.

\section{TABLE C.3. First Stage Results Using Within-District Variation in MFI Exposure}

\begin{tabular}{lcccc}
\hline & $(1)$ & $(2)$ & $(3)$ & $(4)$ \\
\hline \multirow{2}{*}{ Fraction of Exposed GLP } & $-281.230^{*}$ & & $-286.102^{*}$ & \\
& $(153.888)$ & & $(152.983)$ & \\
Exposed MFI Dummy & & $-152.945^{*}$ & & $-164.125^{* *}$ \\
& & $(79.155)$ & & $(75.633)$ \\
Logarithm of MFI Size & & & $-20.994 * *$ & $-23.445^{* * *}$ \\
& & & $(8.479)$ & $(8.505)$ \\
Constant & 1.725 & 7.240 & $446.802 * *$ & $505.342^{* * *}$ \\
& $(6.805)$ & $(9.290)$ & $(180.345)$ & $(181.804)$ \\
Observations & 426 & 426 & 426 & 426
\end{tabular}

Note: Analysis uses within-district variation modeled after Khwaja and Mian (2008). All identifying variation comes from districts with both exposed and unexposed MFIs. Outcomes data from MFI balance sheets. In each column, the dependent variable is the difference of per rural household GLP by the MFI to the district between September 2010 and March 2012. In columns (1) and (3), exposure of the MFI is captured by the share of its portfolio in Andhra Pradesh as of September 2010. In columns (2) and (4), we use a exposure dummy equal to one if the MFI operates in Andhra Pradesh. All specifications include district dummies. In columns (3) and (4), the logarithm of the total portfolio of the MFI is also used as control. The sample is restricted only to MFI-district pairs with positive GLP. Standard errors are clustered at the district level. 
TABLE C.4. Exposure to the AP Crisis and MFI lending (narrow measure): NSS round 70 data

\begin{tabular}{lcc}
\hline & $\begin{array}{c}(1) \\
\text { MFI amt } \\
\text { outstanding, }\end{array}$ & $\begin{array}{c}\text { MFI amt } \\
\text { outstanding, } \\
\text { log. }\end{array}$ \\
\hline Any exposed lender $\times$ Post 2010 & $-271.838^{* * *}$ & $-0.234 * * *$ \\
& $(85.468)$ & $(0.081)$ \\
Exposure Ratio $\times$ Post 2010 & $-111.528 * * *$ & $-0.106 * * *$ \\
& $(33.172)$ & $(0.030)$ \\
\hline Control mean & 391.485 & -6.578 \\
Control SD & 4004.849 & 2.309 \\
Observations & 33559 & 33559 \\
\hline
\end{tabular}

Note: Outcomes data from the NSS 70th round "Debt and Investment" survey reflecting outstanding credit on June 30, 2012. Each cell provides coefficients from separate OLS regression specification. The first row reports coefficients from separate regressions using the binary indicator for high exposure to AP. The second row reports coefficients from separate regressions using the standardized continuous exposure measure. The measure of MFI credit is total SHG-NBFC credit outstanding. The dependent variables in column 1 is in levels, and in $\log (\mathrm{X}+1)$ transformation for column 2. All columns include pre-crisis districtlevel controls. Balance sheet controls include levels and quintiles of GLP measured in both 2008 and 2010. RBI controls include amount of credit outstanding and number of accounts for agricultural loans, direct loans, and indirect loans. NSS 66 controls include average monthly household expenditures, annual durables expenditures, weekly earnings from and days worked in self-employment, daily wage, and percent of weekly earnings from self-employment. Other controls are Round 66 average district consumption, average casual wage and linear distance to AP interacted with round for survey months before July. Standard errors are clustered at the district level. Observations are weighted by NSS sampling weights. 


\section{C.3. Crop Yields.}

TABLE C.5. Crop Yields

\begin{tabular}{lcccccc}
\hline & $\begin{array}{c}(1) \\
\text { Crop Yield } \\
\text { Index }\end{array}$ & $\begin{array}{c}\text { Rice } \\
\text { Yield }\end{array}$ & $\begin{array}{c}\text { Wheat } \\
\text { Yield }\end{array}$ & $\begin{array}{c}\text { Jowar } \\
\text { Yield }\end{array}$ & $\begin{array}{c}\text { Sugarcane } \\
\text { Yield }\end{array}$ & $\begin{array}{c}\text { Groudnut } \\
\text { Yield }\end{array}$ \\
\hline \multirow{3}{*}{ Any exposed lender $\times$ Post 2010 } & -0.002 & -0.028 & 0.061 & 0.049 & -3.858 & -0.046 \\
& $(0.046)$ & $(0.097)$ & $(0.085)$ & $(0.068)$ & $(3.924)$ & $(0.078)$ \\
Exposure Ratio $\times$ Post 2010 & 0.014 & 0.008 & 0.010 & 0.029 & -1.600 & 0.029 \\
& $(0.020)$ & $(0.044)$ & $(0.039)$ & $(0.031)$ & $(1.670)$ & $(0.035)$ \\
\hline Control mean & 0.145 & 2.706 & 2.714 & 1.033 & 73.480 & 1.674 \\
Control SD & 0.192 & 0.880 & 1.116 & 0.433 & 38.551 & 0.926 \\
Observations & 963 & 910 & 783 & 622 & 833 & 758 \\
\hline
\end{tabular}

Note: Outcomes data from the Ministry of Agriculture, Directorate of Economics and Statistics. Index in column 1 is a revenue-weighted average of the log of yield for the five major crops: rice, wheat, sugarcane, jowar (sorghum), and groundnuts. Yields in columns 2-6 are in tonnes per hectare. The first rows provides coefficients using the binary indicator for high exposure to AP. The second rows report specifications that use the standardized continuous exposure measure. In all columns, controls include Round 66 average district consumption, average casual wage and linear distance to AP interacted with round, number of rural households and its squared term, GLP quintiles in 2008 and 2010 dummies along with round fixed effects. Standard errors are clustered at the district level.

\section{C.4. Robustness: Reduced Form Results.}

TABLE C.6. Robustness: Placebo

\begin{tabular}{lccccc}
\hline & $\begin{array}{c}(1) \\
\text { HH Monthly } \\
\text { Consumption: } \\
\text { Total }\end{array}$ & $\begin{array}{c}\text { HH Monthly } \\
\text { Consumption: } \\
\text { Durables }\end{array}$ & $\begin{array}{c}\text { HH Weekly } \\
\text { Labor } \\
\text { Earnings }\end{array}$ & $\begin{array}{c}\text { HH Weekly } \\
\text { Casual Days } \\
\text { Worked }\end{array}$ & $\begin{array}{c}\text { Casual } \\
\text { Daily } \\
\text { Wage }\end{array}$ \\
\hline Any Exposed Lender $\times$ Post 2008 & -13.468 & 15.855 & -7.526 & -0.053 & 0.265 \\
& $(89.466)$ & $(17.008)$ & $(23.988)$ & $(0.208)$ & $(1.573)$ \\
Exposure Ratio $\times$ Post 2008 & -79.651 & -54.363 & 12.079 & 0.138 & -1.926 \\
Observations & $(314.869)$ & $(50.476)$ & $(98.027)$ & $(0.847)$ & $(6.386)$ \\
\hline
\end{tabular}

Note: Outcomes data from NSS rounds 64 and 66. Each cell provides coefficients from separate differencesin-differences regressions. The first row reports coefficients from separate regressions using the binary indicator for high exposure to AP. The second row reports specifications that use the standardized continuous exposure measure. In all columns, controls include Round 64 average district consumption, average casual wage and linear distance to AP interacted with round, quintiles of household size, number of rural households and its squared term, GLP quintiles in 2008 dummies along with round and survey month fixed effects. Standard errors are clustered at the district level. Observations are weighted by NSS sampling weights. 
TABLE C.7. Robustness: Sequential Exclusion of States

\begin{tabular}{|c|c|c|c|c|c|c|c|c|c|c|c|c|c|c|c|c|c|c|}
\hline & (1) & (2) & (3) & (4) & (5) & (6) & (7) & (8) & (9) & (10) & (11) & (12) & (13) & (14) & (15) & (16) & (17) & (18) \\
\hline Excluding: & AS & $\mathrm{BR}$ & CG & GJ & HR & $\mathrm{HP}$ & $\mathrm{JH}$ & $\mathrm{KA}$ & $\mathrm{KL}$ & MP & MH & $\mathrm{OD}$ & $\mathrm{PB}$ & $\mathrm{RJ}$ & $\mathrm{TN}$ & UP & UK & WB \\
\hline \multicolumn{19}{|l|}{ Durable consumption: } \\
\hline ost 2010 & $-65.7 * * *$ & $-71.4^{* * * *}$ & $\begin{array}{c}-64.2^{* * * * *} \\
(23,2)\end{array}$ & $-66.0^{* * * *}$ & $-63.1 * * * *$ & $-65.6 * * *$ & $-65.8^{* * *}$ & $-54.1^{* * *}$ & $-60.9 * * *$ & $-65.8^{* * * *}$ & $-67.3^{* * * *}$ & $-67.3^{* * * *}$ & $-67.7 * * *$ & $-68.0^{* * * *}$ & $-67.0^{* * *}$ & $-65.0^{* * *}$ & $-66.4^{* * * *}$ & $-63.0^{* * * *}$ \\
\hline Exposure Ratio $\times$ Post 2010 & $\begin{array}{c}-24.6 * * \\
(10.3)\end{array}$ & $\begin{array}{c}-27.0 * * * * \\
(10.3)\end{array}$ & $\begin{array}{c}-23.6^{* * *} \\
(10.3)\end{array}$ & $\begin{array}{c}-28.2^{* * * *} \\
(10.4)\end{array}$ & $\begin{array}{c}-24.0^{* * *} \\
(10.3)\end{array}$ & $\begin{array}{c}-24.6 * * \\
(10.3)\end{array}$ & $\begin{array}{c}-24.5^{* *} \\
(10.3)\end{array}$ & $\begin{array}{l}-18.6^{*} \\
(10.5)\end{array}$ & $\begin{array}{c}-26.3^{* * * *} \\
(9.5)\end{array}$ & $\begin{array}{c}-23.2^{* * *} \\
(10.8)\end{array}$ & $\begin{array}{c}-30.7 * * * * * \\
(11.5)\end{array}$ & $\begin{array}{c}-24.7 * * \\
(10.8)\end{array}$ & $\begin{array}{l}-25.3 * * \\
(10.3)\end{array}$ & $\begin{array}{c}-22.3 * * \\
(10.5)\end{array}$ & $\begin{array}{c}-23.6^{* * *} \\
(10.3)\end{array}$ & $\begin{array}{c}-23.9 * * \\
(12.1)\end{array}$ & $\begin{array}{l}-24.9 * * \\
(10.4)\end{array}$ & $\begin{array}{l}-23.9 * * \\
(10.4)\end{array}$ \\
\hline \multicolumn{19}{|l|}{ Casual wage: } \\
\hline Any exposed le & $\begin{array}{c}-6.7 * * \\
(3.2)\end{array}$ & $\begin{array}{c}-7.6^{* * *} \\
(3.0)\end{array}$ & $\begin{array}{l}-6.0^{*} \\
(3.1)\end{array}$ & $\begin{array}{c}-7.4 * * \\
(3.1)\end{array}$ & $\begin{array}{c}-6.5 * * \\
(3.1)\end{array}$ & $\begin{array}{c}-6.7 * * \\
(3.1)\end{array}$ & $\begin{array}{c}-6.7 * * \\
(3.2)\end{array}$ & $\begin{array}{l}-5.8^{*} \\
(3.4)\end{array}$ & $\begin{array}{l}-5.8^{*} \\
(3.0)\end{array}$ & $\begin{array}{l}-5.4^{*} \\
(3.1)\end{array}$ & $\begin{array}{l}-6.2^{*} \\
(3.5)\end{array}$ & $\begin{array}{c}-7.4 * * \\
(3.2)\end{array}$ & $\begin{array}{c}-6.7 * * \\
(3.2)\end{array}$ & $\begin{array}{c}-6.5 * * \\
(3.2)\end{array}$ & $\begin{array}{c}-7.3 * * \\
(3.2)\end{array}$ & $\begin{array}{c}-8.7 * * * * \\
(3.2)\end{array}$ & $\begin{array}{c}-6.7 * * \\
(3.2)\end{array}$ & $\begin{array}{c}-7.4 * * \\
(3.4)\end{array}$ \\
\hline Exposure Ratio $\times$ Post 2010 & $\begin{array}{c}-3.3^{* * *} \\
(1.4)\end{array}$ & $\begin{array}{c}-3.7 * * * * \\
(1.4)\end{array}$ & $\begin{array}{c}-2.9 * * \\
(1.4)\end{array}$ & $\begin{array}{c}-4.0 * * * \\
(1.4)\end{array}$ & $\begin{array}{c}-3.2^{* * *} \\
(1.4)\end{array}$ & $\begin{array}{c}-3.3 * * \\
(1.4)\end{array}$ & $\begin{array}{c}-3.3 * * \\
(1.4)\end{array}$ & $\begin{array}{l}-2.77^{*} \\
(1.5)\end{array}$ & $\begin{array}{c}-3.2 * * \\
(1.4)\end{array}$ & $\begin{array}{c}-2.9 * * \\
(1.5)\end{array}$ & $\begin{array}{l}-2.9 \\
(1.8)\end{array}$ & $\begin{array}{c}-3.7 * * \\
(1.5)\end{array}$ & $\begin{array}{c}-3.3 * * \\
(1.4)\end{array}$ & $\begin{array}{c}-3.1 * * \\
(1.4)\end{array}$ & $\begin{array}{c}-3.2 * * \\
(1.5)\end{array}$ & $\begin{array}{c}-3.9 * * * \\
(1.4)\end{array}$ & $\begin{array}{c}-3.3^{* * *} \\
(1.4)\end{array}$ & $\begin{array}{c}-3.5 * * \\
(1.5)\end{array}$ \\
\hline \\
\hline & $\begin{array}{c}-90.5^{* * * *} \\
(32.6)\end{array}$ & $\begin{array}{c}-83.4 * * \\
(33.6)\end{array}$ & $\begin{array}{c}-84.9 * * * \\
(32.4)\end{array}$ & $\begin{array}{c}-85.3^{* * *} \\
(33.1)\end{array}$ & $\begin{array}{c}-88.6^{* * * *} \\
(32.5)\end{array}$ & $\begin{array}{c}-88.6^{6 * * *} \\
(32.5)\end{array}$ & $\begin{array}{c}-75.0^{* * *} \\
(30.4)\end{array}$ & $\begin{array}{c}-87.2^{* * *} \\
(34.0)\end{array}$ & $\begin{array}{c}-89.1^{* * * *} \\
(32.3)\end{array}$ & $\begin{array}{c}-73.0^{* * *} \\
(32.8)\end{array}$ & $\begin{array}{c}-95.5^{5 * * *} \\
(34.5)\end{array}$ & $\begin{array}{c}-86.2^{* * *} \\
(33.4)\end{array}$ & $\begin{array}{c}-90.1 * * * \\
(32.5)\end{array}$ & $\begin{array}{c}-80.4^{* * *} \\
(33.0)\end{array}$ & $\begin{array}{c}-96.0^{* * * *} \\
(32.7)\end{array}$ & $\begin{array}{c}-107.0^{* * * * *} \\
(35.4)\end{array}$ & $\begin{array}{c}-90.1^{* * * *} \\
(32.5)\end{array}$ & $\begin{array}{c}-100.2^{* * * * *} \\
(34.5)\end{array}$ \\
\hline Exposure Ratio $\times$ Post 2010 & $\begin{array}{c}-43.4 * * * * \\
(15.6)\end{array}$ & $\begin{array}{c}-40.4 * * * \\
(16.4)\end{array}$ & $\begin{array}{c}-40.6 * * * * \\
(15.6)\end{array}$ & $\begin{array}{c}-42.9 * * * * \\
(15.8)\end{array}$ & $\begin{array}{c}-42.7 * * * * \\
(15.7)\end{array}$ & $\begin{array}{c}-42.8 * * * * \\
(15.6)\end{array}$ & $\begin{array}{c}-37.6 * * * \\
(14.9)\end{array}$ & $\begin{array}{c}-44.5 * * * * \\
(16.2)\end{array}$ & $\begin{array}{c}-43.5 * * * * \\
(15.6)\end{array}$ & $\begin{array}{c}-35.4 * * * \\
(16.1)\end{array}$ & $\begin{array}{c}-46.1 * * * * \\
(16.6)\end{array}$ & $\begin{array}{c}-41.8^{* * *} \\
(16.3)\end{array}$ & $\begin{array}{c}-43.4 * * * * \\
(15.7)\end{array}$ & $\begin{array}{c}-38.9^{* * *} \\
(16.2)\end{array}$ & $\begin{array}{c}-41.4 * * * * \\
(15.7)\end{array}$ & $\begin{array}{c}-47.1^{* * * *} \\
(16.4)\end{array}$ & $\begin{array}{c}-43.4 * * * * \\
(15.7)\end{array}$ & $\begin{array}{c}-46.0^{* * * * *} \\
(15.8)\end{array}$ \\
\hline vation & 119412 & 115856 & 118756 & 117471 & 118229 & 119668 & 118612 & 114937 & 114675 & 114651 & 109971 & 114983 & 118844 & 113512 & 117188 & 107536 & 119138 & 112646 \\
\hline
\end{tabular}

Note: Outcomes data from NSS rounds $64,66,68$. In each panel, each row provides coefficients from separate differences-in-differences regressions. The first row reports coefficients from separate regressions using the binary indicator for high exposure to AP. The second row reports specifications that use the standardized continuous exposure measure. In all columns, controls include Round 66 average district consumption, average casual wage and linear distance to AP interacted with round, quintiles of household size, number of rural households and its squared term, GLP quintiles in 2008 and 2010 dummies along with round and survey month fixed effects. In the first panel, the dependent variable is monthly durable expenditures. In the second panel, the dependent variable is the casual daily wage. In the third panel, the dependent variable is weekly labor earnings. In each column, observations in the state indicated at the top of the column are excluded from the sample; all other 17 states are included. Observations are weighted by NSS sampling weights. 
Randomization Inference. We construct randomization inference (RI) p-values by performing 500 permutations, in each of which a different draw of 132 districts were selected to be assigned the status of "exposed." If our results arise from a chance correlation between exposure to the crisis and negative outcomes, then many permutations that randomly assign "exposure" will generate similar patterns. On the other hand, if the observed results are far in the tails of the distribution generated by the RI procedure, this suggests that they are not arising by chance. Reassuringly, for all of the key consumption and labor market outcomes examined $^{44}$, the p-values are 0.020 or smaller, indicating that the actual coefficients are very unlikely to be due to spurious correlation.

TABLE C.8. Randomization Inference: District Level Permutations

\begin{tabular}{lcccc}
\hline & $\begin{array}{c}(1) \\
\text { HH Monthly } \\
\text { Consumption: } \\
\text { Durables }\end{array}$ & $\begin{array}{c}\text { HH Weekly } \\
\text { Labor } \\
\text { Earnings }\end{array}$ & $\begin{array}{c}\text { HH Weekly } \\
\text { Casual Days } \\
\text { Worked }\end{array}$ & $\begin{array}{c}(4) \\
\text { Casual } \\
\text { Daily } \\
\text { Wage }\end{array}$ \\
\hline Estimated Coefficient & $\begin{array}{c}-41.714 * * \\
\text { (-2.49) }\end{array}$ & $\begin{array}{c}-86.227 * * * \\
(-2.84)\end{array}$ & $\begin{array}{c}-0.446^{* *} \\
(-2.28)\end{array}$ & $\begin{array}{c}-6.432 * * \\
(-2.18)\end{array}$ \\
& & & & \\
Distribution Mean & -6.622 & 57.58 & .123 & 0.733 \\
Rank & $3 / 500$ & $0 / 500$ & $0 / 500$ & $5 / 500$ \\
P-value & 0.012 & 0.000 & 0.000 & 0.020 \\
\hline
\end{tabular}

Note: "Estimated coefficient" refers to the exposure effect using the dummy exposure variable and comes from the specification shown in table 7 (durable consumption) or table 6 (other outcomes). "Distribution mean" refers to the distribution of estimated coefficients on permutations of the exposure dummy across districts. There were 500 iterations; at each iteration, 132 districts were randomly selected to have an exposure dummy equal to 1 , while the remaining districts had an exposure dummy equal to 0 . The rank indicates how the estimated coefficient in the data is located in the distribution of simulated coefficients. The $p$-value refers to a two-sided test based on the distribution of the coefficients.

Placebo Shocks. Another, related, concern is that the states that were exposed to AP might also have been exposed, via trade or other linkages, to negative shocks originating elsewhere and thus, we might attribute effects to exposure to the AP crisis that were instead due to some other factor. To address this issue, we permute the identity of the state in which the placebo "crisis" takes place. There are 23 states other than AP in our dataset, but only 22 unique placebo shocks, because a single MFI in our sample operated in both Sikkim and Tripura before the AP crisis, and therefore these states are counted as a single permutation. Thus, we construct 22 placebo measures of exposure (via MFI balance sheets): exposure to Assam, exposure to Bihar, etc. Appendix Table C.9 reports the results. For all of the key

\footnotetext{
${ }^{44}$ We perform the randomization inference exercises using the binary exposure instrument; hence, we examine the key outcomes for which we estimate significant effects in this specification: durable consumption, weekly labor earnings. weekly casual days worked, and the casual daily wage.
} 
consumption and labor market outcomes examined, the true measure of exposure (to AP) generates outcomes that are the lowest or second-lowest in the distribution.

TABLE C.9. Placebo Shocks: State Level Permutations

\begin{tabular}{lcccc}
\hline & $\begin{array}{c}(1) \\
\text { HH Monthly } \\
\text { Consumption: } \\
\text { Durables }\end{array}$ & $\begin{array}{c}\text { HH Weekly } \\
\text { Labor } \\
\text { Earnings }\end{array}$ & $\begin{array}{c}\text { HH Weekly } \\
\text { Casual Days } \\
\text { Worked }\end{array}$ & $\begin{array}{c}\text { Casual } \\
\text { Daily } \\
\text { Wage }\end{array}$ \\
\hline Estimated Coefficient & $-41.714 * *$ & $-86.227 * * *$ & $-0.446 * *$ & $-6.432 * *$ \\
& $(-2.49)$ & $(-2.84)$ & $(-2.28)$ & $(-2.18)$ \\
Distribution Mean & -18.02 & -33.54 & -.222 & -.480 \\
Rank & $1 / 22$ & $2 / 22$ & $3 / 22$ & $4 / 22$ \\
\hline
\end{tabular}

Note: "Estimated coefficient" refers to the exposure effect using the dummy exposure variable and comes from the specification shown in table 7 (durable consumption) or table 6 (other outcomes). "Distribution mean" refers to the distribution of estimated coefficients on permutations of the exposure dummy across MFIs; a district is exposed if an "exposed" MFI operated in it in 2010. There were 22 permutations; at each permutation, a single state was selected and a district was exposed if in October 2010 there was an MFI which operated in both the district and the selected state. For each regression, the sample does not include Andhra Pradesh or the selected "exposed" state. Since a single MFI in our sample operated in both Sikkim and Tripura before the AP crisis, these states are counted as a single permutation. The rank indicates how the estimated coefficient in the data is located in the distribution of simulated coefficients.

TABLE C.10. Robustness: Political Party

\begin{tabular}{lccccc}
\hline & $\begin{array}{c}(1) \\
\text { HH Monthly } \\
\text { Consumption: } \\
\text { Total }\end{array}$ & $\begin{array}{c}\text { HH Monthly } \\
\text { Consumption: } \\
\text { Durables }\end{array}$ & $\begin{array}{c}\text { HH Weekly } \\
\text { Labor } \\
\text { Earnings }\end{array}$ & $\begin{array}{c}\text { HH Weekly } \\
\text { Casual Days } \\
\text { Worked }\end{array}$ & $\begin{array}{c}\text { Casual } \\
\text { Daily } \\
\text { Wage }\end{array}$ \\
\hline Party-times-round fixed effects: & & & & & \\
Any exposed lender $\times$ Post 2010 & -248.060 & $-58.776 * *$ & $-72.559 * *$ & -0.195 & $-7.261^{* *}$ \\
& $(150.488)$ & $(28.784)$ & $(34.908)$ & $(0.232)$ & $(3.229)$ \\
Exposure Ratio $\times$ Post 2010 & $-232.279 * * *$ & -20.931 & $-34.770 * *$ & -0.025 & $-3.919 * * *$ \\
& $(63.601)$ & $(12.949)$ & $(16.959)$ & $(0.107)$ & $(1.431)$ \\
Observations & 111692 & 111692 & 119668 & 119668 & 40584 \\
\hline Same as AP-times-round fixed effects: & -194.996 & $-42.608 *$ & $-89.279 * * *$ & $-0.437 * *$ & $-6.788 * *$ \\
Any exposed lender $\times$ Post 2010 & $(135.254)$ & $(23.763)$ & $(32.644)$ & $(0.208)$ & $(3.282)$ \\
& $-183.984 * * *$ & -14.000 & $-43.234 * * *$ & -0.147 & $-3.378 * *$ \\
Exposure Ratio $\times$ Post 2010 & $(59.327)$ & $(10.888)$ & $(15.966)$ & $(0.094)$ & $(1.518)$ \\
Observations & 111692 & 111692 & 119668 & 119668 & 40584 \\
\hline
\end{tabular}

Note: Outcomes data from NSS rounds 64, 66, 68. Each row provides coefficients from separate differencesin-differences regressions. The first row reports coefficients from separate regressions using the binary indicator for high exposure to AP. The second row reports specifications that use the standardized continuous exposure measure. In all columns, controls include Round 66 average district consumption, average casual wage and linear distance to AP interacted with round, quintiles of household size, number of rural households and its squared term, GLP quintiles in 2008 and 2010 dummies along with round and survey month fixed effects and the party affiliation of the state prime-minister in 2010 times round. Observations are weighted by NSS sampling weights. 
TABLE C.11. Robustness: Rainfall

\begin{tabular}{lccccc}
\hline & $(1)$ & $(2)$ & $(3)$ & $(4)$ & $(5)$ \\
& $\begin{array}{c}\text { HH Monthly } \\
\text { Consumption: } \\
\text { Total }\end{array}$ & $\begin{array}{c}\text { HH Monthly } \\
\text { Consumption: } \\
\text { Durables }\end{array}$ & $\begin{array}{c}\text { HH Weekly } \\
\text { Labor } \\
\text { Earnings }\end{array}$ & $\begin{array}{c}\text { HH Weekly } \\
\text { Casual Days } \\
\text { Worked }\end{array}$ & $\begin{array}{c}\text { Casual } \\
\text { Daily } \\
\text { Wage }\end{array}$ \\
\hline \multirow{2}{*}{ Any exposed lender $\times$ Post 2010} & -112.756 & $-60.775^{* * *}$ & $-85.028^{* * *}$ & $-0.438^{* *}$ & $-5.881^{*}$ \\
& $(125.586)$ & $(22.651)$ & $(32.703)$ & $(0.195)$ & $(3.112)$ \\
Exposure Ratio $\times$ Post 2010 & $-135.512^{* *}$ & $-21.455^{* *}$ & $-40.718^{* * *}$ & $-0.148^{*}$ & $-2.818^{* *}$ \\
& $(55.132)$ & $(9.921)$ & $(15.626)$ & $(0.090)$ & $(1.425)$ \\
Observations & 111692 & 111692 & 119668 & 119668 & 40584 \\
\hline
\end{tabular}

Note: Outcomes data from NSS rounds 64, 66, 68. Each row provides coefficients from separate differencesin-differences regressions. The first row reports coefficients from separate regressions using the binary indicator for high exposure to AP. The second row reports specifications that use the standardized continuous exposure measure. In all columns, controls include Round 66 average district consumption, average casual wage and linear distance to AP interacted with round, quintiles of household size, number of rural households and its squared term, GLP quintiles in 2008 and 2010 dummies along with round and survey month fixed effects and rainfall shocks. Rainfall data is from the Global Precipitation Climatology Centre (GPCC) and rainfall shocks are calculated as in Jayachandran (2006): if rainfall in a year is above the 80-th percentile of the rainfall distribution from 1950-2014, then the rainfall shock equals 1; if it is below the 20-th percentile, the rainfall shock equals -1; otherwise, its value is zero. Observations are weighted by NSS sampling weights. 


\section{TABLE C.12. Robustness: Initial Economic Conditions}

\begin{tabular}{|c|c|c|c|c|c|}
\hline & $\begin{array}{c}\text { (1) } \\
\text { HH Monthly } \\
\text { Consumption: } \\
\text { Total }\end{array}$ & $\begin{array}{c}\text { (2) } \\
\text { HH Monthly } \\
\text { Consumption: } \\
\text { Durables }\end{array}$ & $\begin{array}{c}\text { (3) } \\
\text { HH Weekly } \\
\text { Labor } \\
\text { Earnings }\end{array}$ & $\begin{array}{c}(4) \\
\text { HH Weekly } \\
\text { Casual Days } \\
\text { Worked }\end{array}$ & $\begin{array}{l}(5) \\
\text { Casual } \\
\text { Daily } \\
\text { Wage }\end{array}$ \\
\hline \multicolumn{6}{|l|}{ Panel A: SHG presence $\times$ round } \\
\hline Any exposed lender $\times$ Post 2010 & $\begin{array}{c}-120.081 \\
(0.324)\end{array}$ & $\begin{array}{c}-35.775^{* *} \\
(0.028)\end{array}$ & $\begin{array}{c}-74.132 * * \\
(0.015)\end{array}$ & $\begin{array}{c}-0.433 * * \\
(0.033)\end{array}$ & $\begin{array}{c}-5.251^{*} \\
(0.079)\end{array}$ \\
\hline Observations & 106656 & 106656 & 114499 & 114499 & 39037 \\
\hline Exposure Ratio $\times$ Post 2010 & $\begin{array}{c}-142.699 * * * \\
(52.706)\end{array}$ & $\begin{array}{c}-14.435^{* *} \\
(7.167)\end{array}$ & $\begin{array}{c}-39.904 * * * \\
(14.176)\end{array}$ & $\begin{array}{l}-0.141 \\
(0.093)\end{array}$ & $\begin{array}{c}-2.820 * * \\
(1.347)\end{array}$ \\
\hline Observations & 106656 & 106656 & 114499 & 114499 & 39037 \\
\hline \multicolumn{6}{|c|}{ Panel B: Poverty head count $\times$ round } \\
\hline Any exposed lender $\times$ Post 2010 & $\begin{array}{l}-163.518 \\
(128.440)\end{array}$ & $\begin{array}{c}-67.885^{* * *} \\
(22.973)\end{array}$ & $\begin{array}{c}-89.655^{* * * *} \\
(32.410)\end{array}$ & $\begin{array}{c}-0.454 * * \\
(0.197)\end{array}$ & $\begin{array}{c}-6.631^{* *} \\
(3.130)\end{array}$ \\
\hline Exposure Ratio $\times$ Post 2010 & $\begin{array}{c}-163.967 * * * \\
(55.490)\end{array}$ & $\begin{array}{c}-25.243 * * \\
(10.124)\end{array}$ & $\begin{array}{c}-43.126 * * * \\
(15.547)\end{array}$ & $\begin{array}{l}-0.156^{*} \\
(0.090)\end{array}$ & $\begin{array}{c}-3.279 * * \\
(1.437)\end{array}$ \\
\hline Observations & 111692 & 111692 & 119668 & 119668 & 40584 \\
\hline \multicolumn{6}{|c|}{ Panel C: Share of self-employment $\times$ round } \\
\hline Any exposed lender $\times$ Post 2010 & $\begin{array}{c}-152.798 \\
(129.072)\end{array}$ & $\begin{array}{c}-65.418 * * * \\
(23.088)\end{array}$ & $\begin{array}{c}-88.455^{* * * *} \\
(32.473)\end{array}$ & $\begin{array}{c}-0.450 * * \\
(0.193)\end{array}$ & $\begin{array}{c}-6.647 * * \\
(3.148)\end{array}$ \\
\hline Exposure Ratio $\times$ Post 2010 & $\begin{array}{c}-162.086 * * * \\
(55.893)\end{array}$ & $\begin{array}{c}-24.656^{* *} \\
(10.246)\end{array}$ & $\begin{array}{c}-42.876 * * * \\
(15.580)\end{array}$ & $\begin{array}{l}-0.152^{*} \\
(0.089)\end{array}$ & $\begin{array}{c}-3.306^{* *} \\
(1.432)\end{array}$ \\
\hline Observations & 111692 & 111692 & 119668 & 119668 & 40584 \\
\hline
\end{tabular}

Note: Outcomes data from NSS rounds $64,66,68$. In each panel, each row provides coefficients from separate differences-in-differences regressions. The first row reports coefficients from separate regressions using the binary indicator for high exposure to AP. The second row reports specifications that use the standardized continuous exposure measure. In all columns, controls include Round 66 average district consumption, average casual wage and linear distance to AP interacted with round, quintiles of household size, number of rural households and its squared term, GLP quintiles in 2008 and 2010 dummies along with round and survey month fixed effects. In each panel, additional controls are included: the district-level number of indirect finance accounts per capita from RBI data in 2008 times round (first panel) district poverty head count in round 66 times round (second panel), district share in self-employment times round (third panel). Standard errors are clustered at the district level. Observations are weighted by NSS sampling weights. 
TABLE C.13. Robustness: Migration

\begin{tabular}{|c|c|c|c|c|c|}
\hline \multicolumn{6}{|c|}{ Panel A: Household size as an outcome } \\
\hline \multirow{2}{*}{\multicolumn{6}{|c|}{$\begin{array}{c}(1) \\
\text { H size }\end{array}$}} \\
\hline \multicolumn{5}{|c|}{ HH size } & \\
\hline Any exposed lender $\times$ Post 2010 & $\begin{array}{c}0.017 \\
(0.024)\end{array}$ & & & & \\
\hline Exposure Ratio $\times$ Post 2010 & $\begin{array}{c}0.006 \\
(0.011)\end{array}$ & & & & \\
\hline \multirow[t]{2}{*}{ Observations } & 119668 & & & & \\
\hline & $\begin{array}{c}\text { (1) } \\
\text { HH Monthly } \\
\text { Consumption: } \\
\text { Total }\end{array}$ & $\begin{array}{c}\text { (2) } \\
\text { HH Monthly } \\
\text { Consumption: } \\
\text { Durables }\end{array}$ & $\begin{array}{c}\text { (3) } \\
\text { HH Weekly } \\
\text { Labor } \\
\text { Earnings } \\
\end{array}$ & $\begin{array}{c}(4) \\
\text { HH Weekly } \\
\text { Casual Days } \\
\text { Worked } \\
\end{array}$ & $\begin{array}{l}(5) \\
\text { Casual } \\
\text { Daily } \\
\text { Wage } \\
\end{array}$ \\
\hline \multicolumn{6}{|c|}{ Panel B: Total migration in round $64 \times$ round } \\
\hline Any exposed lender $\times$ Post 2010 & $\begin{array}{l}-140.445 \\
(119.182)\end{array}$ & $\begin{array}{c}-42.362 * * \\
(16.910)\end{array}$ & $\begin{array}{c}-84.179^{* * *} \\
(30.395)\end{array}$ & $\begin{array}{c}-0.424 * * \\
(0.195)\end{array}$ & $\begin{array}{c}-6.443 * * \\
(2.953)\end{array}$ \\
\hline Exposure Ratio $\times$ Post 2010 & $\begin{array}{c}-153.583 * * * \\
(51.864)\end{array}$ & $\begin{array}{c}-17.580 * * \\
(7.636)\end{array}$ & $\begin{array}{c}-43.631 * * * \\
(14.173)\end{array}$ & $\begin{array}{l}-0.139 \\
(0.090)\end{array}$ & $\begin{array}{c}-3.455^{* *} \\
(1.340)\end{array}$ \\
\hline Observations & 111692 & 111692 & 119668 & 119668 & 40584 \\
\hline \multicolumn{6}{|c|}{ Panel C: Migration below median in round $64 \times$ round } \\
\hline Any exposed lender $\times$ Post 2010 & $\begin{array}{c}-133.540 \\
(118.853)\end{array}$ & $\begin{array}{c}-42.701 * * \\
(16.808)\end{array}$ & $\begin{array}{c}-84.560 * * * \\
(30.251)\end{array}$ & $\begin{array}{c}-0.442 * * \\
(0.196)\end{array}$ & $\begin{array}{c}-6.358^{* * *} \\
(2.940)\end{array}$ \\
\hline Exposure Ratio $\times$ Post 2010 & $\begin{array}{c}-149.186 * * * \\
(51.946)\end{array}$ & $\begin{array}{c}-17.719^{* *} \\
(7.542)\end{array}$ & $\begin{array}{c}-43.932 * * * \\
(14.102)\end{array}$ & $\begin{array}{l}-0.151^{*} \\
(0.090)\end{array}$ & $\begin{array}{c}-3.396^{* *} \\
(1.332)\end{array}$ \\
\hline Observations & 111692 & 111692 & 119668 & 119668 & 40584 \\
\hline
\end{tabular}

Note: Outcomes data from NSS rounds $64,66,68$. In each panel, each row provides coefficients from separate differences-in-differences regressions. The first row reports coefficients from separate regressions using the binary indicator for high exposure to AP. The second row reports specifications that use the standardized continuous exposure measure. In all columns, controls include Round 66 average district consumption, average casual wage and linear distance to AP interacted with round, quintiles of household size, number of rural households and its squared term, GLP quintiles in 2008 and 2010 dummies along with round and survey month fixed effects. In Panels B and C, additional controls are included: the migration rate in round 64 times round (Panel B), and an indicator for a district having an above- vs. below-median migration rate in round 64 times round (Panel C). Standard errors are clustered at the district level. Observations are weighted by NSS sampling weights. 
TABLE C.14. Robustness: Quantile regressions

\begin{tabular}{|c|c|c|c|c|c|}
\hline & $\begin{array}{c}\text { (1) } \\
\text { HH Monthly } \\
\text { Consumption: } \\
\text { Total }\end{array}$ & $\begin{array}{c}(2) \\
\text { HH Monthly } \\
\text { Consumption: } \\
\text { Durables }\end{array}$ & $\begin{array}{c}\text { (3) } \\
\text { HH Weekly } \\
\text { Labor } \\
\text { Earnings } \\
\end{array}$ & $\begin{array}{c}(4) \\
\text { HH Weekly } \\
\text { Casual Days } \\
\text { Worked }\end{array}$ & $\begin{array}{c}(5) \\
\text { Casual } \\
\text { Daily } \\
\text { Wage } \\
\end{array}$ \\
\hline \multicolumn{6}{|c|}{ Panel A: 25th percentile regression } \\
\hline Exposure Ratio $\times$ Post 2010 & $\begin{array}{l}-29.177 \\
(37.351)\end{array}$ & $\begin{array}{c}5.328 \\
(3.474)\end{array}$ & $\begin{array}{c}-21.353 * * * \\
(7.610)\end{array}$ & $\begin{array}{l}-0.041 \\
(0.033)\end{array}$ & $\begin{array}{l}-1.337 \\
(1.418)\end{array}$ \\
\hline Control mean & 6945.676 & 658.482 & 1086.034 & 2.634 & 176.244 \\
\hline Control SD & 6518.771 & 3045.746 & 1996.492 & 4.622 & 107.029 \\
\hline Observations & 111692 & 111692 & 119668 & 119668 & 40584 \\
\hline \multicolumn{6}{|l|}{ Panel B: Median regression } \\
\hline Exposure Ratio $\times$ Post 2010 & $\begin{array}{c}-137.117 * * \\
(57.158)\end{array}$ & $\begin{array}{c}-9.775 * * \\
(4.815)\end{array}$ & $\begin{array}{c}-21.600 * * \\
(8.992)\end{array}$ & $\begin{array}{l}-0.056 \\
(0.034)\end{array}$ & $\begin{array}{c}-3.380 * * \\
(1.592)\end{array}$ \\
\hline Control mean & 6945.676 & 658.482 & 1086.034 & 2.634 & 153.361 \\
\hline Control SD & 6518.771 & 3045.746 & 1996.492 & 4.622 & 87.097 \\
\hline Observations & 111692 & 111692 & 119668 & 119668 & 40584 \\
\hline \multicolumn{6}{|c|}{ Panel C: 75th percentile regression } \\
\hline Exposure Ratio $\times$ Post $2010^{\circ}$ & $\begin{array}{c}-301.318 * * * \\
(85.134)\end{array}$ & $\begin{array}{c}-52.596 * * * \\
(16.284)\end{array}$ & $\begin{array}{l}-22.572 \\
(31.810)\end{array}$ & $\begin{array}{c}-0.221 * * \\
(0.100)\end{array}$ & $\begin{array}{l}-5.180^{*} \\
(2.840)\end{array}$ \\
\hline Control mean & 6945.676 & 658.482 & 1086.034 & 2.634 & 176.244 \\
\hline Control SD & 6518.771 & 3045.746 & 1996.492 & 4.622 & 107.029 \\
\hline Observations & 111692 & 111692 & 119668 & 119668 & 40584 \\
\hline
\end{tabular}

Note: Outcome data from NSS rounds 64, 66, 68. In each panel, each column provides coefficients from separate differences-in-differences quantile regression using the standardized continuous exposure measure. In all columns, controls include Round 66 average district consumption, average casual wage and linear distance to AP interacted with round, quintiles of household size, number of rural households and its squared term, GLP quintiles in 2008 and 2010 dummies along with round and survey month fixed effects. Standard errors are cluster bootstrapped (250 repetitions) at the district level. Observations are weighted by NSS sampling weights.

TABLE C.15. Robustness: Unweighted regressions

\begin{tabular}{lccccc}
\hline & $\begin{array}{c}(1) \\
\text { HH Monthly } \\
\text { Consumption: } \\
\text { Total }\end{array}$ & $\begin{array}{c}\text { HH Monthly } \\
\text { Consumption: } \\
\text { Durables }\end{array}$ & $\begin{array}{c}\text { HH Weekly } \\
\text { Labor } \\
\text { Earnings }\end{array}$ & $\begin{array}{c}\text { HH Weekly } \\
\text { Casual Days } \\
\text { Worked }\end{array}$ & $\begin{array}{c}\text { Casual } \\
\text { Daily } \\
\text { Wage }\end{array}$ \\
\hline Exposure Ratio $\times$ Post 2010 & $-190.278^{* * *}$ & $-52.856^{* * *}$ & -22.206 & $-0.140^{* *}$ & $-3.481^{*}$ \\
& $(64.124)$ & $(14.314)$ & $(20.938)$ & $(0.064)$ & $(2.016)$ \\
\hline Control mean & 6945.676 & 658.482 & 1086.034 & 2.634 & 176.244 \\
Control SD & 6518.771 & 3045.746 & 1996.492 & 4.622 & 107.029 \\
Observations & 111692 & 111692 & 119668 & 119668 & 40584 \\
\hline
\end{tabular}

Note: Outcome data from NSS rounds 64, 66, 68. In each panel, each column provides coefficients from separate differences-in-differences quantile regression using the standardized continuous exposure measure. In all columns, controls include Round 66 average district consumption, average casual wage and linear distance to AP interacted with round, quintiles of household size, number of rural households and its squared term, GLP quintiles in 2008 and 2010 dummies along with round and survey month fixed effects. Standard errors are clustered at the district level. 
TABLE C.16. Robustness: Unwinsorized regressions

\begin{tabular}{lccccc}
\hline & $\begin{array}{c}(1) \\
\text { HH Monthly } \\
\text { Consumption: } \\
\text { Total }\end{array}$ & $\begin{array}{c}\text { HH Monthly } \\
\text { Consumption: } \\
\text { Durables }\end{array}$ & $\begin{array}{c}\text { HH Weekly } \\
\text { Labor } \\
\text { Earnings }\end{array}$ & $\begin{array}{c}\text { HH Weekly } \\
\text { Casual Days } \\
\text { Worked }\end{array}$ & $\begin{array}{c}(5) \\
\text { Casual } \\
\text { Daily } \\
\text { Wage }\end{array}$ \\
\hline Exposure Ratio $\times$ Post 2010 & $-161.333^{* * *}$ & $-24.567^{* *}$ & $-42.821^{* * * *}$ & $-0.154^{*}$ & $-3.380^{* *}$ \\
& $(56.368)$ & $(10.291)$ & $(15.635)$ & $(0.089)$ & $(1.592)$ \\
\hline Control mean & 5643.397 & 382.247 & 854.812 & 3.455 & 153.361 \\
Control SD & 4531.698 & 1891.396 & 1434.832 & 5.134 & 87.097 \\
Observations & 111692 & 111692 & 119668 & 119668 & 40584 \\
\hline
\end{tabular}

Note: Outcome data from NSS rounds 64, 66, 68. In each panel, each column provides coefficients from separate differences-in-differences quantile regression using the standardized continuous exposure measure. In all columns, controls include Round 66 average district consumption, average casual wage and linear distance to AP interacted with round, quintiles of household size, number of rural households and its squared term, GLP quintiles in 2008 and 2010 dummies along with round and survey month fixed effects. Standard errors are clustered at the district level. Observations are weighted by NSS sampling weights.

TABLE C.17. Robustness: Sharpened FDR q-values

\begin{tabular}{lcccccc}
\hline & $(1)$ & $(2)$ & $(3)$ & $(4)$ & $(5)$ & $(6)$ \\
& $\begin{array}{c}\text { HH Monthly } \\
\text { Consumption: } \\
\text { Total }\end{array}$ & $\begin{array}{c}\text { HH Monthly } \\
\text { Consumption: } \\
\text { Durables }\end{array}$ & $\begin{array}{c}\text { HH Weekly } \\
\text { Labor } \\
\text { Earnings }\end{array}$ & $\begin{array}{c}\text { HH Weekly } \\
\text { Casual Days } \\
\text { Worked }\end{array}$ & $\begin{array}{c}\text { Casual } \\
\text { Daily } \\
\text { Wage }\end{array}$ & $\begin{array}{c}\text { MFI amt } \\
\text { outstanding, } \\
\text { rd. 70 }\end{array}$ \\
\hline Exposure Ratio $\times$ Post 2010 & $-151.222^{* * *}$ & $-17.130^{* *}$ & $-44.836^{* * *}$ & $-0.154^{*}$ & $-3.439^{* *}$ & $-111.528^{* * *}$ \\
Unadjusted p-val & $(0.004)$ & $(0.023)$ & $(0.002)$ & $(0.087)$ & $(0.010)$ & $(0.001)$ \\
Sharpened FDR q-val & $(0.007)$ & $(0.014)$ & $(0.007)$ & $(0.029)$ & $(0.009)$ & $(0.007)$
\end{tabular}

Note: Outcome data in cols 1-5 from NSS rounds 64, 66, 68. Outcomes data in col 6 from NSS round 70. Each column provides coefficients from separate differences-in-differences quantile regression using the standardized continuous exposure measure. In columns 1-5, controls include Round 66 average district consumption, average casual wage and linear distance to AP interacted with round, quintiles of household size, number of rural households and its squared term, GLP quintiles in 2008 and 2010 dummies along with round and survey month fixed effects. Standard errors are clustered at the district level. Observations are weighted by NSS sampling weights. FDR sharpened q-values are Benjamini Krieger Yekutieli (2006) sharpened qvalues. Sharpened FDR q-vals can be less than unadjusted p-vals when many hypotheses are rejected. 
C.5. Alternate Exposure Measure using Predicted MFI Locations. As we discuss in Section 5.1, we use the information in the data from the reporting MFIs to better understand determinants of where MFIs lend. Specifically, we run the following logistic regression for reporting lenders:

$$
\begin{aligned}
L_{m, d}= & \alpha+\beta_{1} \text { Dist }_{h(m), d}+\beta_{2} G L P_{m}^{l}+\beta_{3} \text { Dist }_{h(m), d} \times G L P_{m}^{l}+ \\
& \gamma_{1} \text { SameState }_{h(m), d}+\gamma_{3} \text { SameState }_{h(m), d} \times G L P_{m}^{l}+\varepsilon_{m, d}
\end{aligned}
$$

where $m$ indexes MFI and $d$ indexes district. $L_{m, d}$ is an indicator for whether MFI $m$ has a positive loan portfolio in district $d$ in 2010, prior to the ordinance. Dist $t_{h(m), d}$ denotes the distance between district $d$ and $h(m)$, the headquarters of the MFI. $G L P_{m}^{l}$ denotes the MFI's lagged India-wide gross loan portfolio $m$. Finally SameState $_{h(m), d}$ is an indicator for district $d$ being located in the same state as $h(m)$, the MFI's headquarters. ${ }^{45}$

Table C.18 presents the results for the sample of reporting MFIs. The table indicates that MFIs are indeed more likely to lend closer to their headquarters. However, this relationship weakens as MFIs become larger by loan volume and expand to wider geographies.

TABLE C.18. Correlates of MFI Location Decisions

\begin{tabular}{lcc}
\hline & $(1)$ & $(2)$ \\
& Probability of lending in a district & Marginal effect \\
\hline & & \\
District distance to MFI HQ & $-0.024^{* * *}$ & $-0.000^{*}$ \\
District in Same State as MFI HQ & $(0.008)$ & $(0.000)$ \\
Lagged Log GLP & -0.774 & -0.002 \\
& $(9.739)$ & $(0.025)$ \\
Distance to HQ x Lagged Log GLP & 0.473 & 0.001 \\
& $(0.315)$ & $(0.001)$ \\
Same State as HQ x Lagged Log GLP & $0.001^{* * *}$ & $0.000^{*}$ \\
& $(0.000)$ & $0.000)$ \\
Observations & 0.152 & 0.000 \\
\hline
\end{tabular}

Note: Table reports the coefficients and marginal effects from a logistic regression measuring the correlate's of the MFI's location decision. Observations are at the district by MFI level. The outcome variable is an indicator for whether each MFI has an active loan portfolio in a given district prior to October 2010 and comes from the MFI location and lending data obtained by the authors. Column 1 shows the log-odds logit coefficient estimates, which column 2 represents the marginal effects. The errors are clustered at the MFI level.

\footnotetext{
${ }^{45}$ We obtain information on the location of the MFI's headquarters from each MFI's public website, and we obtain India-wide portfolio information from the MIX Market database.
} 
We next use publicly available data for the non-reporting MFIs on total lagged portfolio value and the address of the headquarter (from the MIX database and lender websites, respectively) to predict whether each lender had a strictly positive lending portfolio in each district prior to the crisis.

Next, we combine the actual locations for reporting MFIs and the predicted locations for non-reporting MFIs to construct an alternate exposure measure. The procedure is similar to that of Section 3.1 .

The key difference is the way in which we construct each MFI's exposure share to AP. Rather than $f r a c A P_{l}$, we construct ${\overline{\operatorname{frac} A P_{l}}}_{l}$

$$
{\overline{\text { frac } A P_{l}}}_{l}=\frac{\sum_{d \in A P} 1\left(G L P_{d, l, \text { Oct } 2010}>0\right)}{\sum_{d^{\prime}} 1\left(G L P_{d^{\prime}, l, \text { Total }, \text { Oct } 2010}>0\right)} .
$$

Then, for each district, we construct an aggregate exposure measure by taking the weighted average of $\overline{f r a c A P_{l}}$ over all lenders who had outstanding loans in the district pre-crisis:

$$
{\overline{\operatorname{Exp} A P_{d}}}_{d}=\frac{\sum_{l}{\overline{\operatorname{frac} A P_{l}}}_{l} \times 1\left(G L P_{d, l, O c t 2010}>0\right)}{\sum_{l} 1\left(G L P_{d, l, O c t 2010}>0\right)}
$$

Table C.19 reports the first stage and reduced form results using this alternative exposure measure $\overline{\operatorname{ExpAP}}_{d}$ : 
TABLE C.19. Results: Predicted Exposure

\begin{tabular}{|c|c|c|c|c|c|c|c|}
\hline & $\begin{array}{c}\text { (1) } \\
\text { MFI } \\
\text { amt } \\
\text { outstanding. }\end{array}$ & $\begin{array}{c}(2) \\
\text { Casual } \\
\text { Daily } \\
\text { Wage }\end{array}$ & $\begin{array}{c}\text { (3) } \\
\text { HH Weekly } \\
\text { Labor } \\
\text { Earnings }\end{array}$ & $\begin{array}{c}\text { (4) } \\
\mathrm{HH} \\
\text { is an } \\
\text { Employer }\end{array}$ & $\begin{array}{c}\text { (5) } \\
\text { HH monthly } \\
\text { Consumption: } \\
\text { Total }\end{array}$ & $\begin{array}{c}\text { (6) } \\
\text { HH monthly } \\
\text { Consumption: } \\
\text { Non-durables }\end{array}$ & $\begin{array}{c}\text { (7) } \\
\text { HH monthly } \\
\text { Consumption: } \\
\text { Durables }\end{array}$ \\
\hline Predicted Exposure Ratio $\times$ Post 2010 & $\begin{array}{c}-451.077 * * \\
(190.554)\end{array}$ & $\begin{array}{l}-1.612 \\
(1.277)\end{array}$ & $\begin{array}{l}-25.165^{*} \\
(13.839)\end{array}$ & $\begin{array}{c}-0.005^{* *} \\
(0.002)\end{array}$ & $\begin{array}{c}-139.157 * * * \\
(50.506)\end{array}$ & $\begin{array}{c}-124.476^{* * *} \\
(44.836)\end{array}$ & $\begin{array}{l}-10.422 \\
(7.844)\end{array}$ \\
\hline Observations & 33559 & 40584 & 119668 & 119668 & 111692 & 119668 & 111692 \\
\hline
\end{tabular}

Note: Table presents key results, using predicted exposure, as described in Section 5.1. Predicting MFI exposure allows us to include all of the MFIs present in the MIX Microfinance database. In all columns, controls include Round 66 average district consumption, average casual wage and linear distance to AP interacted with round, quintiles of household size, number of rural households and its squared term, GLP quintiles in 2008 and 2010 dummies along with round and survey month fixed effects. The outcome of interest in columns 1 is total total formal, non-bank, non-collateralized credit (i.e., microfinance credit). Outcomes in columns (1) to (3) are winsorized at the 99th percentile. Standard errors are clustered at the district level. Observations are weighted by NSS sampling weights. 
C.6. Impacts on Predicted Borrowers. Unfortunately, we are not able to run our main reduced form results separately for borrwers and non-borrowers. This is for two reasons. First, the NSS surveys are repeated cross sections, not panels, so we cannot follow households across time. (We can, of course, follow districts over time.) Second, our main postcrisis consumption and employment outcomes come from the 68th round of the NSS, which does not include any information on borrowing.

To come one step closer to linking our reduced form results with MFI borrowing more directly, we conduct the following exercise using the NSS 70 data. Unlike rounds 64, 66 and 68 (which contain consumption and employment modules), round 70 contains a detailed Debt and Investment module, allowing us to observe the level and composition of household borrowing. Thus, in the round 70 cross section, we can observe microfinance borrowing and household and business investment for the same set of households. We proceed in three steps. First, we use predetermined covariates to predict microfinance borrowing for a random subset of households (ie, a training sample) in districts with no exposure to the crisis. (Specifically, we use the following pre-determined variables as predictors: household size, number of prime age females, number of prime age males, maximum education level in the household, education of the spouse, an indicator for whether the household is engaged in any agricultural activity, caste category, religion, and pre-crisis total lending in the district.) Second, we construct a predicted borrowing measure for the validation sample in unexposed districts and for all households in exposed districts. Third, we replicate the investment regressions from Appendix Table 7, allowing for heterogeneity in the impacts for predicted MFI borrowers vs. predicted non-borrowers. The results of this exercise are presented in Table C.20.

We do find larger impacts for total and household investment for predicted MFI borrowers than non-borrowers, consistent with a direct aggregate demand channel coming from a fall in spending by the likely MFI borrowers. This is in line with the findings of Kaboski and Townsend (2012), who find a large effect on home investment resulting from an increase in microcredit access in Thailand. Also note that the fact that there are significant effects on total investment and non-agricultural business investment for predicted non-borrowers is consistent with the presence of general equilbrium impacts.

We do caution the reader that these results rely on many assumptions, and we interpret them as suggestive evidence consistent with our narrative. 
TABLE C.20. Exposure to the AP Crisis and Investment, by Predicted MFI Borrower Type

\begin{tabular}{lcccc}
\hline & $\begin{array}{c}(1) \\
\text { Total } \\
\text { Investment }\end{array}$ & $\begin{array}{c}(2) \\
\text { Home } \\
\text { Improvements }\end{array}$ & $\begin{array}{c}\text { Ag. Business } \\
\text { Investment }\end{array}$ & $\begin{array}{c}\text { Non-Ag Business } \\
\text { Investment }\end{array}$ \\
\hline Exposure Ratio & & & & \\
& $-674.618^{* *}$ & -359.455 & -56.526 & $-47.657^{* * *}$ \\
Exposure Ratio $\times$ Predicted MF Borrower & $(290.081)$ & $(225.383)$ & $(66.529)$ & $(14.726)$ \\
& $-1182.454^{* *}$ & $-1210.769^{* * *}$ & 157.554 & -37.640 \\
Control mean & $(563.635)$ & $(432.092)$ & $(137.071)$ & $(50.114)$ \\
Control SD & 5928.313 & 3576.154 & 914.612 & 243.185 \\
Observations & 25579.598 & 18654.310 & 4294.964 & 1511.672 \\
\hline
\end{tabular}

Note: Outcomes data from the NSS 70th round "Debt and Investment" survey reflecting investments made in home improvements and businesses between July 1, 2012 and December 31, 2012. Each column provides coefficients from separate OLS regression specification using the standardized continuous measure of exposure. The dependent variables are levels and at the top 1 percentile. All columns include pre-crisis district-level controls. Balance sheet controls include levels and quintiles of GLP measured in both 2008 and 2010. RBI controls include amount of credit outstanding and number of accounts for agricultural loans, direct loans, and indirect loans. NSS 66 controls include average monthly household expenditures, annual durables expenditures, weekly earnings from and days worked in self-employment, daily wage, and percent of weekly earnings from self-employment. Other controls are Round 66 average district consumption, average casual wage and linear distance to AP interacted with round for survey months before July. Standard errors are clustered at the district level. Observations are weighted by NSS sampling weights. 


\section{C.7. Exposure to Andhra Pradesh.}

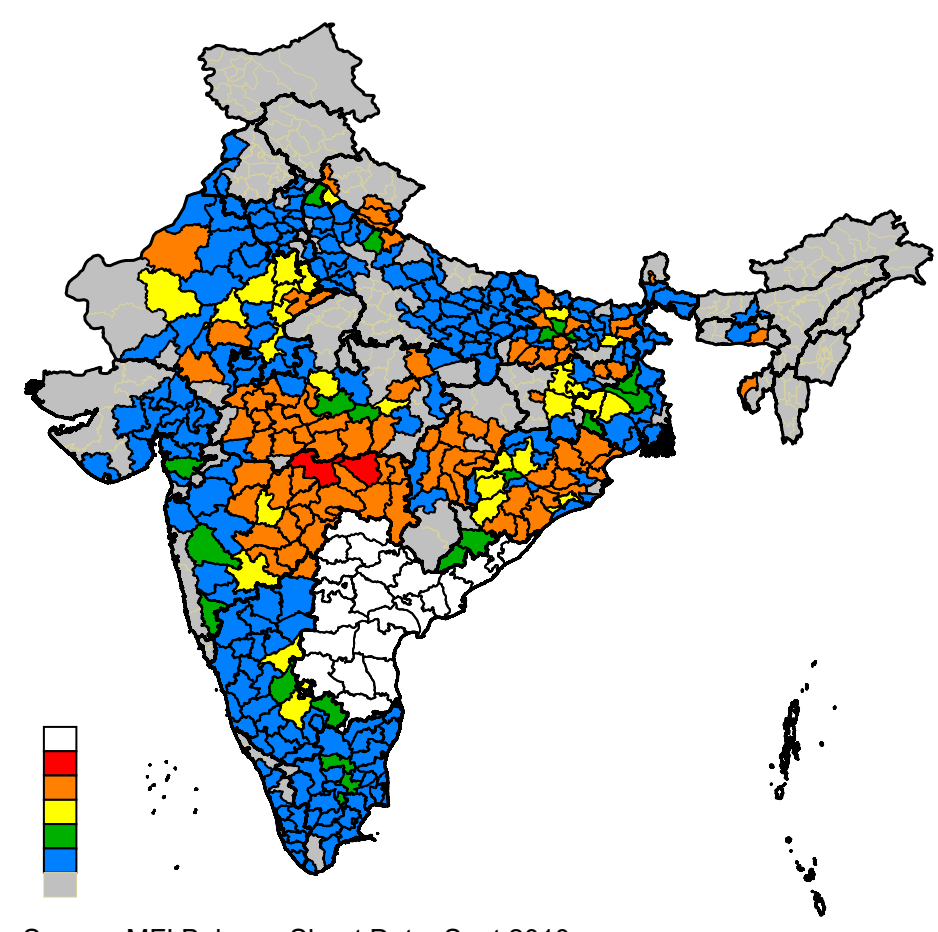

Source: MFI Balance Sheet Data, Sept 2010.

Figure C.1. Exposure to Andhra Pradesh

Note: The figure shows the exposure of each district in our sample to Andhra Pradesh, using the continuous exposure measure from Section 3.1. Gray $=$ no data; blue $=0$ exposure; green $=<1$ std dev; yellow $=<2$ std dev; orange $=<3$ std dev; red $=<4$ std dev; white $=$ AP . 


\section{APPENDiX D. DATA APPENDiX}

D.1. Household Survey Data. Household level data are from several rounds of the National Sample Survey (NSS). Most of the analysis in the paper refers to rounds 64, 66 and 68. Round 64 was conducted from July 2007 until June 2008. Round 66 was conducted from July 2009 until June 2010. Finally, round 68 was conducted from July 2011 until June 2012, after the Andhra Pradesh crisis in October 2010. We also used the round 70 of the NSS (January 2013 - December 2013), in particular the Debt and Investment schedule.

We now discuss how household level variables are constructed from the National Sample Surveys, rounds 64, 66 and 68. All the questions refer to the questionnaire from Schedule 10 ("Employment, Unemployment and Migration Particulars").

Labor and Earnings Variables In round 64, labor information is from block 5, while for rounds 66 and 68 it is from block 5.3. Casual labor wages are calculated at the household level as the ratio between the sum of total weekly earnings across household members and the total number of days worked in the week. Earnings are in column 17 and worked days are in column 14. Wages and earnings are restricted to status 51 ("casual labor in nonpublic works"). Prime age individuals are those between 18 to 45 years old. We classify the work as agricultural if the 2-digit NIC-2004 code is 1, and as non-agricultural otherwise. Total weekly days worked correspond to the sum of column 14 among household members with activity status (column 4) below 72, so it excludes domestic activities and education time. Casual weekly days worked correspond to the sum of column 14 among household members with activity status 41 ("casual wage labor in public works other than NREG public works"), 42 (“casual wage labor in NREG public works"), or 51 (“casual labor in non-public works"). Household weekly labor earnings correspond to the sum of column 17 among all household members with activity status (column 4) below 72. A household has a member in unemployment if the status (column 4) equals 81 ("did not work but was seeking and/or available for work") for some household member. A household has any non-agricultural self employment if the status (column 4) is less or equal than 21 and the 2-digit NIC-2004 code is larger than 1 for some household member.

Consumption Variables From round 64, monthly household total consumption expenditure is the sum of the answers to items 16 ("sub-total (items 1 to 15)") and 21 ("sub-total (items 17 to 20)") of block 7 ("household consumer expenditure"), with the latter normalized to represent monthly expenditure, instead of yearly. Durable consumption expenditure is from the answer to item 20 of block 7, again scaled to reflect the monthly average in the past year. Non-durable consumption expenditure is given by summing item 16 with items 17-19 of block 7, the latter normalized to reflect the monthly average. From round 
66 , monthly household total consumption expenditure is the answer to item 40 of block 9. Durable consumption expenditure is the sum of items 29 to 37 of block 9 , scaled to reflect the monthly average in the past year. Non-durable consumption is the sum of item 23 and the monthly equivalent of the sum of item 24 to 28 . From round 68, monthly household total consumption expenditure is the answer to item 40 of block 8 . Durable consumption expenditure is the sum of itens 29 to 37 of block 8 , scaled to reflect the monthly average in the past year. Non-durable consumption is the sum of item 23 and the monthly equivalent of the sum of item 24 to 28 . Finally, the poverty dummy is constructed by comparing per capita household total consumption with the state-round specific rural poverty line from the Planning Commission, Government of India, "Report of the Expert Group to Review the Methodology for Measurement of Poverty", 2014.

Household Size and Landholdings For any round, household size is the answer to item 1 of block 3 and household land holdings are from item 7 of block 3 .

D.2. Banking Data. District-level banking data is from the Basic Statistical Returns of Scheduled Commercial Banks in India provided by the Reserve Bank of India (RBI). This information is available at http://dbie.rbi.org.in/DBIE/dbie.rbi?site= publications\#! 9 . In particular, the data comes from Table 5.9., "District-Wise Classification of Outstanding Credit of Scheduled Commercial Banks".

D.3. Poverty Data. An indicator for whether a household is below the poverty line is constructed by comparing total per capita monthly consumption with the state-specific rural poverty lines presented in the document "Report of the expert group to review the methodology for measurement of poverty" (Government of India Planning Commission 2014). This report is available at http: / / planningcommission.nic.in/reports/genrep/ pov_rep 0707 . pdf. See Table B1, pg. 28 and B2,B3,B4 pgs. 29-31. Values for 2007-08 are obtained by inflation-adjusting the $2009-10$ values.

D.4. Crop Yield Data. District-level crop yield data is constructed from the Crop Production Statistics Information System, Directorate of Economics and Statistics, Ministry of Agriculture and Farmers Welfare (http: / / aps.dac.gov.in/APY/Index.htm). The crop index is constructed in a similar way as in Jayachandran (2006). For each district and each of the five crops, (Sugarcane, Rice, Groundnut, Wheat and Sorghum), we normalize yields to 1 in 2008 and take the weighted average of the logarithms. Weights are the revenue share of each crop. The only difference to the measure in Jayachandran is that we normalize the yields by the initial yields, instead of the average yield across all periods. Also, Jayachandran (2006) uses local prices in order to measure the revenue associated to 
each crop, while we use a national 2008 price index for each crop. The price indexes are available from FAOSTAT.

D.5. Rainfall. Rainfall data is from the Global Precipitation Climatology Center (GPCC), available at http://www.esrl.noaa.gov/psd/data/gridded/data.gpcc. html. The original dataset contains a $0.5 \times 0.5$ degree grid on monthly precipitation, which is interpolated from weather station data. For each district in our sample, we assign the rainfall of the grid point closest to the district centroid. Monthly rainfall is averaged at the year level. We construct rainfall shocks as in Jayachandran (2006). If rainfall in a year is above the 80-th percentile of the rainfall distribution for that district from 1950-2014, then the rainfall shock equals 1 ; if it is below the 20th percentile, the rainfall shock equals -1 ; otherwise, its value is zero.

D.6. Political Parties. The political party variable is defined as the party affiliation of the chief minister of the state in September, 2010 (on the eve of the crisis). Party affiliation information was collected from states' websites and google searches.

D.7. Road Travel Time. The time travel between Indian districts is from Allen and Atkin (2016). The dataset is available at the authors'websites. We use the travel time calculated for the year 2011.

D.8. MFI balance sheet data. We partnered with MFIN, the primary trade organization of for-profit MFI-NBFCs (non-bank, financial corporations). We worked with MFIN to ask each of their 42 members for total principal outstanding on active loans, by district, at annual intervals between September 2008 and September 2012. In total, 25 of MFIN's 42 member organizations agreed to share their data for the study. 


\section{Appendix E. Calibration Appendix}

Here, we provide details about the calibrations used in Section 6. We allow both channels, the aggregate demand as well as the investment channel, to operate. Households are heterogeneous: some are unconstrained entrepreneurs (who borrow from sources other than microfinance), others are permanently constrained workers (who cannot borrow from microfinance), while we also allow for some individuals to be potential microfinance customers. To match the previous literature, we allow some microfinance borrowers to have a consumption motive, while others use microfinance to start a productive business.

E.1. Workers. All households are endowed with a labor endowment in both the tradable and non-tradable sector. Worker households supply $\left(\ell_{T}, \ell_{N T}\right)$ inelastically to each market.

Worker households (denoted by type $\omega$ ) maximize utility, subject to the within-period budget constraints:

$$
\begin{gathered}
\max _{C_{t}^{T, \omega}, C_{t}^{N T, \omega}} C_{1}+\beta C_{2} \\
\text { s.t. } C_{t}=\left(C_{t}^{T, \omega}\right)^{\alpha}\left(C_{t}^{N T, \omega}\right)^{1-\alpha} \\
C_{t}^{T, \omega}+P C_{t}^{N T, \omega} \leq \ell_{T} w_{T, t}+\ell_{N T} w_{N T, t}+y_{t}+B_{t}-R B_{t-1}
\end{gathered}
$$

where $\beta$ is the household's discount rate, $w_{k, t}$ is the period $t$ wage in sector $k, y_{t}$ is nonlabor income, and $B_{t}$ is the amount borrowed, discussed below. $R$ is the interest rate on last period's borrowing. Households are fully savings constrained and can only move money between periods by borrowing, if available.

Given the Cobb-Douglas structure, consumers will spend constant budget shares on each good each period:

$$
\begin{aligned}
C_{t}^{T, \omega} & =\alpha\left(\ell_{T} w_{T, t}+\ell_{N T} w_{N T, t}+y_{t}+B_{t}-R B_{t-1}\right) \\
C_{t}^{N T, \omega} & =\frac{1-\alpha}{P_{t}}\left(\ell_{T} w_{T, t}+\ell_{N T} w_{N T, t}+y_{t}+B_{t}-R B_{t-1}\right)
\end{aligned}
$$

where $P_{t}$ is the relative price of the non-tradable good. (We normalize the price of the tradable good each period to 1$)$.

E.2. Entrepreneurs. Some households are endowed with entrepreneurial ability in one of two sectors, $S \in\{T, N T\}$. If they choose to operate a business, the production functions are: 


$$
\begin{aligned}
Y^{T} & =A^{T}\left(L^{T, \ell}\right)^{\gamma} \\
Y^{N T} & =A^{N T}\left(L^{N T, h}\right)^{\gamma}
\end{aligned}
$$

where $\gamma<1$. Note here, that for simplicity, we assume a fully segmented labor market workers can only supply their labor to either the tradable or the non-tradable sector. Market segementation could arise for several reasons. One natural interpretation is skill segmentation. While agricultural day labor requires less skill than masonry or roof thatching, for example. Entrepreneurs maximize profits, $\Pi_{t}^{S}=P_{t}^{S} Y_{t}^{S}-L_{t}^{S} w_{S}$, where $L_{t}^{S} w_{S}$ is shorthand for the total input costs of the sector-specific type of labor and $P_{t}^{S}$ is the price of the good produced by sector $S$ in period $t$.

We assume that running a business in either sector requires the entrepreneur's full human capital. Therefore, potential-entrepreneur households must choose whether to run a business or to supply their labor to the wage labor market. Finally, we assume that opening a business for the first time requires the payment of a fixed cost $\bar{B}$. We assume that unconstrained entrepreneurs are all incumbents and have paid the cost in the past.

Thus, unconstrained entrepreneurs maximize the same objective function as the workers, subject to an entrepreneur and sector-specific budget constraint:

$$
C_{t}^{T, E: S}+P C_{t}^{N T, E: S} \leq \Pi_{S, t}+y_{t}
$$

We need to check that in equilibrium, all unconstrained entrepreneurs receive more utility from running their business than from closing the business and opting into the wage labor market.

E.3. Microfinance Borrowing. While in Appendix A, we considered small changes in the quantities of microfinance available to borrowers, in reality, the AP Crisis led to a large discrete decrease in the loan size. We model the change in credit supply for as a fall in $B$ from $\bar{B}$ to 0 . As shown above in the worker's budget constraint, consumption borrowing increases resources in period 1 by $B$ at a cost of $R B$ in the future.

Microfinance lenders generally target borrowers in the middle of the village income distribution. The poorest individuals are viewed as unable to repay, while the richest households are already less constrained and would have lower demand for credit. Consistent with the empirical facts, we allow for only a fraction of constrained individuals to be able to avail themselves of microcredit. 
We also allow there to be some potential entrepreneurs who have the ability to enter entrepreneurship, but who have not yet paid the fixed cost to set up the business. For these constrained entrepreneurs, they can use the loan to pay this cost. This leads to the following budget constraint for the $E B: S$ types (entrepreneurial borrowers in sector $S$ ).

$$
C_{t}^{T, E B: S}+P C_{t}^{N T, E B: S} \leq \Pi_{S, t}+y_{t}-R B_{t-1}
$$

For an interior microfinance borrowing equilibrium, three conditions must be satisfied:

(1) Borrowers with a consumption motive must have a higher utility from borrowing the fixed quantity $\bar{B}$ than from borrowing 0 and consuming all labor and non-labor earnings.

(2) Constrained T entrepreneurs must prefer to borrow to start a business than to borrow for consumption.

(3) Constrained NT entrepreneurs must prefer to borrow to start a business than to borrow for consumption.

E.4. Types. To summarize the above discussion, the model leads to six different types of agents:

(1) Unconstrained $T$ Entrepreneurs $(E: T)$

(2) Unconstrained $N T$ Entrepreneurs $(E: N T)$

(3) Partially Constrained $T$ Entrepreneurs $(E B: T)$

(4) Partially Constrained NT Entrepreneurs $(E B: T)$

(5) Partially Constrained Workers $\left(\omega^{B}\right)$

(6) Fully Constrained Workers $(\omega)$

We can then define the fraction of agents of each type $\tau$ by $\theta_{\tau}$. The following objects are particularly important: the total fraction of worker households (both borrowers and non-borrowers) $\theta_{\omega}$; the total fraction of T entrepreneurs $\theta_{T}$; and the total fraction of NT entrepreneurs $\theta_{N T}$. Note $\theta_{\omega}+\theta_{T}+\theta_{T E}=1$. The weights will change as a function of the microfinance regime.

E.5. Equilibrium Conditions. In equilibrium, the labor markets and the non-tradable product market must clear:

$$
\begin{gathered}
\theta_{T} L^{T, \ell}=\theta_{\omega} \ell_{T} \\
\theta_{N T} L^{N T, h}=\theta_{\omega} \ell_{N} T
\end{gathered}
$$




$$
\sum_{\tau} N^{\tau} C^{N T, \tau}=\theta_{N T} A^{N T}\left(L^{N T, h}\right)^{\gamma}
$$

As mentioned above, it also needs to be the case that entrepreneurs of both types prefer to use their human capital to run a business rather than to supply labor to the market.

E.6. Parameter Assumptions. To calibrate the model, we have to make numerous simplifying assumptions. We describe our assumptions by family of parameters:

Production function parameters. $\left(\gamma, A^{T}, A^{N T}\right)$ : We set $A^{T}=A^{N T}=4.6$. This value is chosen to match the TFP parameter in Buera et al. (2017). We set the returns to scale parameter, $\gamma=0.535$, again using the value from Buera et al. (2017).

Household parameters. $\left(\ell_{T}, \ell_{N T}, \alpha, y_{1}, y_{2}\right)$ : We set $\ell_{N T}=89.2216, \ell_{T}=104.7384$. The relative endowments of labor in the tradable and non-tradable sectors are set to match the share of casual labor hours supplied in agriculture (53.6\%) and non-agriculture (46.4\%) in the 2012 NSS in control (unexposed) districts. ${ }^{46}$

We set the weight on tradables in the utility function to $\alpha=0.55$. This is the share of total household expenditure that is food and tobacco in the 2012 NSS in control (unexposed) districts. Finally, we set $y_{1}=22.4, y_{2}=60$. The high value of $y_{2}$ relative to $y_{1}$ is chosen to capture, in a reduced form way, the factors that make households desire consumption credit. $^{47}$

Types. $\theta_{\tau}$ We assume that $25 \%$ of households are unconstrained entrepreneurs. Given the unavailability of detailed business information, we make the assumption that $50 \%$ of businesses are tradable and 50\% are nontradable. Finally, the share who borrow from microfinance is set to 0.0932 , which is the share of households who have a microloan in the NSS 70 data, using the broad definition of microfinance, namely non-collateralized formal lending from a non-bank source. As we discuss in Section 4.3, this is the measure that best captures households' total borrowing from microfinance sources.

Borrowing parameters. $(\bar{B}, R)$ : We set the size of a microloan to $\bar{B}=16$, chosen to be $58 \%$ of economy-wide avergage labor earnings, which is the size of a typical microloan as a share of labor earnings in the 2012 NSS in control (unexposed) districts. This number appears large because entrepreneurial households report zero labor earnings and thus bring

\footnotetext{
${ }^{46}$ In the calibrated version of the model we assume full segmentation between the two labor markets, so this is equivalent to choosing the endowments of low- and high-skilled labor.

${ }^{47}$ These factors could include rational expectations of higher income in the future, but also myopic/timeinconsistent preferences or lack of understanding of the terms of microloans.
} 
down the average. We set $R=1.15$. A typical Indian microloan carries a nominal APR of approximately $25 \%$, and inflation was approximately $10 \%$.

E.7. Modeling the Crisis. To generate calibrated treatment effects, we compare the status quo economy, outlined above, with a counterfactual economy experiencing a large negative microcredit supply shock. We calibrate the size of the shock based on our first stage estimates in Table 3. Exposed districts, using the binary measure, experienced a 54\% decine in microcredit borrowing. We assume that this was largely driven by suspending new loan disbersements, and therefore assume that the fraction of potential borrowers fell from $9.32 \%$ to $4.27 \%$. 